



\section{CARTOGRAFÍA DE UNA ESCUELA PARA CLASES POPULARES}

Rocío Fatyass

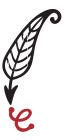

COLECCIÓN 
(C) 2019. Editorial Universitaria Villa María Chile 253 - (5900) Villa María,

(C) 2019. Rocío Fatyass

Córdoba, Argentina

Tel.: +54 (353) 4539145

www.eduvim.com.ar

Editor: Jesica Mariotta

Diseño de tapa y maquetación: Gabriela Callado

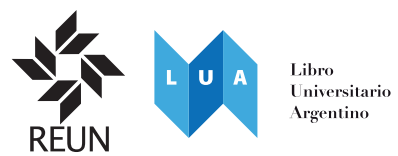

La responsabilidad por las opiniones expresadas en los libros, artículos, estudios y otras colaboraciones publicadas por EDUVIM incumbe exclusivamente a los autores firmantes y su publicación no necesariamente refleja los puntos de vista ni del Director Editorial, ni del Consejo Editor u otra autoridad de la UNVM. No se permite la reproducción total o parcial de este libro, ni su almacenamiento en un sistema informático, ni su transmisión en cualquier forma o por cualquier medio electrónico, mecánico, fotocopia u otros métodos, sin el permiso previo y expreso del Editor.

Impreso en Argentina - Printed in Argentina 


\section{ÍNDICE}

Cartografía de una escuela para clases populares

\section{Capítulo I}

Infancias, educación y Estado

Introducción al estado de las políticas públicas educativas (1990-2014)

La etapa neoliberal

Hacia el enfoque de derechos: continuidades y rupturas con la etapa neoliberal

Tensiones entre condiciones estructurales y prácticas institucionales

\section{Capítulo II}

Representaciones y prácticas de los agentes institucionales

Homologías entre el campo educativo y el campo social genera

Aspectos epistemológicos y metodológicos

La construcción dialéctica del objeto: cartografiando a la escuela del barrio

Métodos y técnicas

\section{Capítulo III}

El barrio

El espacio social reificado: un barrio de clases populares 
La historia del barrio y sus condiciones objetivas

Visiones y divisiones sociales sobre el territorio

\section{Capítulo IV}

El campo escolar

La configuración de la escuela: entre historias de segregación y relatos de contención social

Redes de agencias y campos

\section{Capítulo V}

Actos enclasados

El efecto de trayectoria social

Actos de enclasamiento: lugares comunes y distancias sociales

\section{Capítulo VI}

Actos de enclasamiento: construcciones sobre los alumnos y alumna

Proyectos institucionales

Adaptaciones, integraciones, derivaciones y convenios de conducta

Caracterizando a la jornada extendida

\section{Capítulo VII}

La matriz institucional

Tiempos y espacios escolares

Reflexiones finales

Bibliografía

Documentos oficiales, leyes, programas y proyectos

Documentos institucionales

Entrevistas

Notas de campo

Índice de siglas 
PRESENTACIÓN 

Voy a comparar a menudo el esfuerzo humano de conocer la realidad con esa otra vieja tarea humana que es la de hacer mapas y planos. Así, la vida humana es entre otras cosas, búsqueda constante de motivos para la fiesta, y si los obstáculos dolorosos de la vida están entre los principales estímulos del esfuerzo humano para pensar, conocer, entender y transformar la realidad circundante, entonces podríamos imaginarnos el conocimiento humano como un intento de elaborar mapas para la fiesta: suerte de guías para tratar de encontrar y abrir caminos que nos lleven de vuelta a la buena vida [...]. ${ }^{1}$

1 Maduro, O., Mapas para la fiesta. Reflexiones latinoamericanas sobre la crisis y el conocimiento, Rio de Janeiro-Nueva York, Centro Nueva Tierra, 1992. 


\section{Rocío Fatyass}


Cartografía de una escuela para clases populares

\begin{abstract}
Pablo, un niño de 14 años, me dijo que no sabía leer (...) me senté junto a él y fuimos practicando los sonidos y las letras (...) noté que había algunas pronunciaciones que si reconocía y al animarlo frente a sus compañeros continuó con el ejercicio (...) incluso se sumó al grupo otro niño de 9 años: 'no sé leer, pero quiero aprender'(...).'
\end{abstract}

Bajo la perspectiva de la sociología crítica de la educación, la temática de esta investigación refiere al análisis de los procesos de transmisión del capital escolar en contextos de pobreza, que se desarrollan en el espacio de la jornada extendida de una escuela primaria, ubicada en un barrio popular de la ciudad de Villa María, Córdoba, Argentina, durante el período 2014.

Los antecedentes de este trabajo se relacionan con procesos de intervención en este y otros espacios barriales de la ciudad, ya que desde 2011 se desarrollan proyectos de investigación, extensión y voluntariados universitarios, subsidiados por la Universidad Nacional de Villa María (UNVM). En relación al objeto de estudio, estas instancias permitieron reconocer algunas prácticas y representaciones de las instituciones -entre ellas la escuela- que impactan en la vida de los niños y niñas y acercarse a las miradas de las infancias de clases populares, problematizando su contexto socio-cultural.

Otro antecedente se centra en una investigación subsidiada por la UNVM durante el período 2012-2013: "Prácticas de sectores ppopulares en contextos de pobreza", dirigido por Paula Pavcovich, desde la que se iniciaron los primeros contactos en el barrio de estudio, con los directivos y docentes de la escuela, con referentes de espacios asociativos y con algunas instituciones de la municipalidad presentes en el territorio.

A partir de los primeros resultados, se pudo caracterizar al barrio como uno de los espacios más postergados de la ciu-

Cabe aclarar que se utilizan, durante todo el libro, nombres ficticios para resguardar las identidades de los sujetos, lo cual no modifica los fines de la investigación.

Nota de campo 10, 26-06-2014. 
dad, conformado principalmente por pobres estructurales y, en menor medida, por grupos sociales medios bajos, los cuales se ubican, en términos generales, en una posición desventajosa en la acumulación de capital económico dentro del espacio social global y se encuentran en posición subordinada con respecto a las posibilidades objetivas de acumulación de capital cultural.

El problema de investigación analiza entonces a la escuela primaria como parte de un sistema de enclasamiento institucionalizado. De tal manera, cabe problematizar sobre: I) los significados que los espacios escolares en contextos populares re-producen en referencia a los niños, las niñas y a sus familias; II) si estos sentidos remiten a la "pobreza" y a la "carencia" o a un ideal de inclusión democrática.

Para cartografiar la escuela como un sistema de enclasamiento institucionalizado, se estructura un marco teórico, fundamentalmente, desde la perspectiva bourdieuana y, por su parte, la estrategia metodológica recoge los conceptos de Patricio Bolton $^{2}$ respecto a la matriz de aprendizaje institucional, la transversalidad de lo escolar y la red de sentidos, que en el espacio escolar dan lugar a la construcción de específicos dispositivos áulicos e institucionales.

El diseño metodológico se caracteriza, en términos generales, por la triangulación inter e intra metodológica para abordar la dimensión objetiva y comprensiva de la temática, utilizando técnicas cualitativas y cuantitativas, entre ellas: análisis de datos cuantitativos y cualitativos producto de otras investigaciones $^{3}$; observación participante; registro de campo de tipo etnográfico; entrevistas semi-estructuradas y abiertas a los agentes institucionales; y la construcción de una cartografía sobre

\footnotetext{
2 Bolton, P., Educación y vulnerabilidad: experiencias y prácticas del aula en contextos diferentes, Buenos Aires, Editorial Stella, CELADEC, La Crujía, 2006.

3 Proyectos de investigación dirigidos por Paula Pavcovich "El barrio. Estrategias familiares y efectos de territorio", 2009-2010; “Prácticas de sectores populares en contextos de pobreza", 2012-2013; "Estrategias de reproducción social e infancia(s). Experiencias de niñas, niños y adolescentes de clases populares", 2014-2015; así como proyectos de voluntariados universitarios "Infancias, escuela y universidad" y "Experiencias de participación ciudadana desde la educación popular”, 2013-2015.
} 
las categorías que permiten explicar y comprender prácticas y representaciones en la escuela.

Los capítulos centrales bajos los cuales se enmarca la investigación son los siguientes:

I) El contexto del objeto de estudio, para reconocer, en perspectiva histórica, las intervenciones de diversos agentes y discursos en y con referencia al campo estatal, examinando las relaciones y tensiones entre infancias, educación y Estado, durante un recorte temporal que abarcar desde 1990 hasta el 2014.

II) El marco teórico donde se desarrollan los principales conceptos, desde la teoría estructural-genética de Pierre Bourdieu y la perspectiva de la sociología crítica de la educación, conceptualizando las homologías existentes entre el campo social general -como espacio de las clases sociales- y el campo educativo. Asimismo, conjugando lo teórico con lo metodológico, se describen y analizan aspectos del trabajo de campo, según las dimensiones epistemológicas y metodológicas involucradas, planteándose la hipótesis y los objetivos de la investigación.

III) Para situar las condiciones objetivas y simbólicas en las cuales se halla inserta la escuela, este capítulo caracteriza el espacio físico-social construyendo la posición de clase en relación al volumen y estructura de capital de las familias, así como la historia del barrio y algunos discursos de agentes portavoces sobre las divisiones y visiones presentes en el territorio.

IV) También se construye a la escuela como cuerpo especie de agente colectivo que se relaciona con diversos agentes posicionados “en y por" fuera del campo escolar, mediante el trabajo en red y distintos programas pertenecientes a políticas públicas de la institución.

V) En este capítulo, para objetivar las prácticas enclasadas y enclasantes, se abordan las trayectorias -en el campo educativo- de los agentes institucionales de la jornada extendida, quienes se posicionan de modo particular en la estructura de 
clases, haciendo hincapié en el efecto de trayectoria social, explicando "desde dónde" sus prácticas y discursos oponen posiciones respecto a las familias del barrio.

VI) y VII) para interpretar y comprender las prácticas de enclasamiento se cartografía a la escuela a fin de reconocer las mediaciones pedagógicas que posicionan a los niños y niñas como pobres sujetos de conocimiento en el espacio escolar.

En la conclusión del trabajo se retoman los objetivos, la hipótesis de la investigación y los conceptos e ideas fundamentales de los diferentes capítulos, habilitándose nuevos interrogantes a partir de los resultados obtenidos. 
PRÓLOGO 

Co- Presencias (I)

Presentar los resultados de una investigación supone, siempre, un desafío. En este caso, el desafío se profundiza por varios motivos.

Por una parte, porque este trabajo, articulado sobre los requerimientos de una objetivación fundada en el uso de herramientas propias del campo de la sociología, está contenido en un espacio de investigación colectivo. En este proyecto global fuimos construyendo preguntas y buscando respuestas sobre el mundo social infantil. Para esto avanzamos en un ejercicio teórico-metodológico que posibilitara recuperar la complejidad en la que se sostienen las experiencias de las niñeces de sectores populares. Experiencias que sólo pueden ser abordadas desde su dimensión relacional y en los entramados en los que se juega la condición infantil desde una interseccionalidad atravesada por lógicas de desigualdad, produciendo relaciones que no se agotan en la dimensión de clase, sino que se complejizan en los espacios sociales que conforman nuestros recortes empíricos, incluidos los espacios escolares.

La finalidad de comprender y explicar cómo el mundo social habita -simbólica y materialmente- la vida de niñas y niños pretende evidenciar la infancia -en este caso, en situación de pobreza- como objeto de una disputa por los principios de visión y división social a la que apuntan los intereses adultos. Asimismo, aspira re-conocer los puntos de vista construidos desde las posiciones infantiles, pues las prácticas de niñas y niños no pueden ser reducidas a los requerimientos de una transición que los prepara -pasivamente- para la vida adulta.

Por otra parte, si bien, este escrito representa la culminación de un recorrido individual, el mismo no puede ser entendido sin el acompañamiento de un trabajo colectivo que -en paralelo- fue aportando a la construcción del Centro de Educación Popular para la Infancia y la Adolescencia (Cepia). En este sentido, mi lugar fue armándose sobre los hilos del compromiso 
entre dos educadoras populares que, si bien se sostuvo en el vínculo académico, también fue tejiendo una trama desde el compromiso y encuentro con otras compañeras y compañeros, incluidos las niñas y niños con quienes fuimos experienciando y procesando una pedagogía política, no sólo de la infancia, sino también de la adultez.

De esta manera, el cruce entre una investigación académica y un proceso de producción de conocimiento que explicita su intencionalidad política en la lógica de la educación popular -a la que nos invita Paulo Freire-, habilitó un diálogo entre saberes que involucra aquél que es producido por niñeces de clases populares en diferentes territorios de una ciudad media de la Argentina. Sin embargo, si bien la propuesta de Cepia reconoce los saberes infantiles populares, no lo hace desde un enfoque idealizado que supone que niñas y niños se posicionan en una relación de igualdad con el mundo adulto y clasista. Por esto, el trabajo político pedagógico necesita el insumo de los principios explicativos provenientes del hacer sociológico, para desnaturalizar los procesos de desigualdad social y los mecanismos -sutiles y no tanto- que atraviesan la vida de las infancias populares.

Una escuela, un barrio

Las páginas siguientes nos invitan a traspasar las paredes físicas de una escuela primaria, para así poder comprender cómo éstas van transformándose en verdaderos muros simbólicos que unen y separan a quienes participan de sus encuentros y desencuentros cotidianos.

Un escenario, aparentemente neutral, que va revelando las prácticas de una asimetría marcada por una doble subordinación -de clase y de edad-, que confluye en la imposición del orden social adulto sobre niñas y niños de un barrio en el que la pobreza viene transmitiéndose generacionalmente. 
La escuela de este barrio es analizada como parte de las condiciones materiales de existencia de los grupos sociales que habitan en el territorio y, por qué no, como parte de las condiciones materiales de existencia de las maestras que no lo habitan, pero que allí trabajan. Condiciones que estructuran las miradas, las percepciones, las afectividades y las moralidades que van orientando un trabajo pedagógico cuyos efectos aportan a una acción organizadora de una manera de ser niña, de una manera de ser niño.

La escuela de este barrio es analizada como co-productora -en una escala micro-, de los principios de división social que sostienen el orden adultocéntrico y sociocéntrico. Funda, en la oposición niñez y adultez, las predisposiciones infantiles que van interiorizando en niñas y niños unas definiciones particulares desde las que ellas y ellos construyen una imagen de sí y del mundo en el que viven.

La escuela de este barrio es analizada desde las llamadas al orden social, en las palabras y en los gestos de sus maestras, en los cuerpos adultos e infantiles que la recorren, que se miran y que se (des)conocen. Llamadas que se hacen pensamiento en un mundo de sentido común que produce una segunda naturaleza.

La escuela de este barrio es analizada desde el juego entre lo posible para estas educadoras (pobres conocimientos para niñas y niños pobres), contra lo probable de un espacio educativo (niñas y niños como sujetos -capaces- de conocimiento).

La escuela de este barrio es analizada como parte de las condiciones en las que estas alumnas y alumnos adquieren disposiciones que van delimitando sus expectativas y esperanzas en el horizonte de lo que es para nosotras y nosotros.

La escuela de este barrio es analizada como una institución en la que circulan puntos de vista, juicios, valores, opiniones; que no pueden ser entendidos si no es en el marco de lo que Bourdieu llama una verdadera solidaridad orgánica entre dif- 
erentes espacios sociales desde la que se ejerce el trabajo de dominación que va configurando la aceptación de los dominados. Porque en definitiva, las explicaciones que esgrimen los agentes sociales -sean maestros, madres y padres, trabajadoras sociales, etc.- sobre las prácticas de estas niñeces, son miradas que se toman desde un punto, desde una posición que se relaciona con otras posiciones y oposiciones (la escuela atravesada por la economía, la cultura legítima, las políticas estatales, las políticas comunitarias, la lucha de clase y dentro de ésta: la lucha de competencia).

La escuela de este barrio es analizada, en los propios términos de la investigación, como parte de un sistema de enclasamiento institucionalizado, que no es inmutable ni producto de una necesidad histórica, pero que sí es producto de los equilibrios y desequilibrios de las relaciones de fuerza imperantes y eufemizadas por las relaciones de sentido dominantes en su interior. Institucionalización de un sistema de enclasamiento que es historia, producto de agentes sociales que luchan por pasados que disputan presentes y por presentes que disputan por pasados.

\section{Co-prescencias (II)}

Las prácticas pedagógicas de esta escuela no sólo fueron interpretadas desde unas tomas de posición particulares -como pueden ser las de un grupo de maestras-. También fueron explicadas bourdieusianamente, desde los principios que visibilizaron la reproducción de las relaciones de dominación que tienden a naturalizar las diferencias sociales en un barrio periférico y en su relación con la ciudad de la que es parte.

De allí que el acercamiento de Cepia a ese mundo habitado fue complejizado por el extrañamiento que trata de construir un proceso de investigación como el que se refleja en las páginas de este libro. Complejizar el trabajo político en la lógica freireana, con el análisis de las condiciones que generan el principio 
de producción de prácticas enclasadas y enclasantes forma parte de la propuesta de la acción-reflexión-acción. Así también, el acercamiento de la investigación tradicional a ese mundo habitado necesita de la familiaridad con la que se construyen los vínculos con aquellas y aquellos que protagonizan un estado de infancia (Bustelo), en un trabajo de militancia territorial que interpela maneras de instituir infancia, y, en consecuencia, maneras de instituir adultez.

Así resulta que desde el encuentro de dos formas de acercarse al mundo de las niñeces, surge -en el colectivo de investigación y en el colectivo de intervención- otra línea de problematización: la agencia infantil, pues consideramos que como en toda relación social, niñas y niños también participan en la construcción de sus condiciones de clase y de edad y por tanto, de la sociedad de la que forman parte. 



\section{CAPÍTULO I \\ Infancias, educación y Estado}





\section{¿Todas ustedes van a la universidad?, porque yo cuando sea grande quiero estudiar veterinaria y modista en la universidad de ustedes (...).}

Este capítulo se propone analizar algunos aspectos de las políticas públicas en materia educativa y para las infancias, dimensiones que, situadas a nivel nacional y provincial, impactan en las prácticas y discursos que circulan en la escuela del barrio. Al momento de la investigación el recorte temporal implicó explorar la época de los 90 hasta el año 2014.

La comprensión de las dinámicas sociales mediante las cuales la educación de los niños y niñas es producida, reproducida y transformada supone, por un lado, una reflexión histórica ya que estos cambios no son mecánicos, ni productos de leyes históricas, tampoco el resultado de la planificación racional. Por otro lado, es fundamental problematizar las narrativas hegemónicas institucionalizadas, dado que en estos largos e inacabados procesos una diversidad de agentes proclaman su legitimidad de intervenir respecto a "lo que es mejor para los/as niños/as". Cabe decir que en estas relaciones sociales siempre se negocian algunos sentidos, constituyéndose "un espacio de actualización y desestabilización de las diferencias de poder". ${ }^{2}$

Por tanto, para el estudio de las políticas públicas educativas para las infancias hay que considerar qué se entiende por Estado desde el concepto de campo estatal.

El Estado contribuye en una parte determinante a la producción y a la reproducción de los instrumentos de elaboración de la realidad social. En tanto que "estructura organizadora e instancia reguladora de las prácticas, ejerce de modo permanente una acción formadora de disposiciones duraderas, mediante las imposiciones y las disciplinas a las que somete uniformemente

Nota de campo 7, 05-06-2014.

2 Villalta, C., "Estado, familias e infancia. Técnicas de gestión y dispositivos jurídico-burocráticos destinados a la infancia", Clase XIV, Diploma superior infancia, educación y pedagogía, Cohorte 1, FLACSO Virtual, 2014. 
al conjunto de los agentes"3. Siguiendo con las definiciones de Bourdieu, el campo estatal es

[...] un conjunto de campos administrativos o burocráticos dentro de los cuales agentes y categorías de agentes [...] luchan por esta forma peculiar de autoridad que consiste en el poder de mandar por medio de la legislación, regulaciones, medidas administrativas, en suma, todo lo que normalmente ponemos bajo el rubro de las políticas de Estado como esfera particular de prácticas relacionadas [...]. ${ }^{4}$

El Estado se define entonces como un espacio de lucha donde grupos y agentes con recursos discursivos y no discursivos compiten en un contexto social específico para establecer como hegemónicas sus interpretaciones; esta perspectiva se contrapone a la reificación del Estado y, a su vez, se aleja de la visión estadocéntrica o maquínica.

Como espacio estructurado de relaciones de fuerza y sentido, sujeto a variaciones históricas, el Estado aborda las políticas sociales para las infancias con un doble objetivo, el de garantizar la reproducción del orden social y el de incluir a las nuevas generaciones.

En definitiva, para Pierre Bourdieu ${ }^{5}$ la institucionalización implica que significados culturales y categorías jerárquicas, en este caso en referencia a la educación de los/as niños/as, adquieren apariencia de lo natural, estabilización temporaria y hegemonía relativa. Estas categorías aparentemente descriptivas resultan tanto prescriptivas como performativas.

Las anteriores consideraciones son importantes si se tiene en cuenta que la producción de distintas categorías de infancia menores, alumnos, hijos, etc. - se origina en el marco de la institucionalidad estatal “moderna”. Al respecto, Philippe Ariès ${ }^{6}$ plantea que entre fines del siglo XVIII y principios del XIX, en

\footnotetext{
Bourdieu, P., Meditaciones pascalianas, Barcelona, España, Anagrama, 1999a, pág. 230.

4 Bourdieu, P. y Wacquant, L., Respuestas por una antropología reflexiva, México, Grijalbo, 1995, pág. 168.

5 Bourdieu, P., El sentido práctico, Madrid, Taurus, 1994.

6 ArIÈs, P., El Niño y la vida familiar en el antiguo régimen, Madrid, Taurus, 1987.
} 
Europa, se produjo "el descubrimiento de la infancia" por medio del desarrollo de una "sensibilidad moderna" que acentuó la necesidad del cuidado y protección de los/as niños/as; por lo tanto, aparecen diversos dispositivos -escolares, jurídicos, médicos- para su conocimiento y formación. Para el caso de América Latina la preocupación pública por la niñez comenzó a delinearse y a materializarse en el campo estatal -y no únicamente en el campo religioso- a fines del siglo XIX, según modificaciones en los contextos socio-políticos y económicos de los diferentes países de la región.

Para los Estados nacientes, un sistema de escuelas que "repartieran" los mismos saberes y donde se educara a los futuros ciudadanos, constituyó una alternativa económica y efectiva para lidiar con las diferencias de los individuos y configurar identidades colectivas, lo cual era pensado como una problemática social que necesitaba una intervención pública según los intereses de las elites hegemónicas o elites morales, como plantea Darío Melossi, constituidas por "individuos y grupos que, dentro de pautas dadas, tienen éxito en expresar las posiciones morales que eventualmente se transformarán en hegemónicas". ${ }^{7}$

Para el objeto de estudio es pertinente analizar las correspondencias entre infancias, educación y Estado, pero haciendo un recorte temporal de la complejidad que permita vincular de todos modos la dimensión macro y micro social que involucra este trabajo, ya que las funciones de la escuela se han transformado históricamente desde sus orígenes. En las siguientes caracterizaciones, se mencionan los programas, políticas y leyes que dan cuenta de los cambios -más allá de algunas continuidades y tensiones- en los últimos años con referencia a la época de los 90.

7 Melossi, D., El estado del control social, Buenos Aires, Siglo Veintiuno Editores, 1992, pág. 43. 


\section{INTRODUCCIÓN AL ESTADO DE LAS POLÍTICAS PÚ- BLICAS EDUCATIVAS (1990-2014)}

\section{La etapa neoliberal}

La política educativa bajo los gobiernos de Carlos Saúl Menem (1989-1995/1995-1999) viabilizó la constitución en la Argentina de una nueva corriente tecnocrática. Encontró sus raíces en las líneas educacionales del gobierno de Onganía y, especialmente, en el pensamiento antiestatista del liberalismo oligárquico de la segunda mitad del siglo XX.

La política neoliberal menemista cumplió con las directivas del Banco Mundial -acompañado por el Banco Interamericano de Desarrollo y otros organismos internacionales- que exigían la descentralización de los sistemas escolares, su paulatina transferencia al sector privado, el desfinanciamiento de la educación pública de nivel medio y superior, la flexibilización de la contratación docente y la aplicación de programas focalizados para las clases populares.

La educación, que había sido reconocida tradicionalmente en la Argentina como un bien público -al menos discursivamente-, ahora se consideraba como un elemento del mercado que debía ser regulado por la ley de la oferta y la demanda y según las indicaciones de los “expertos” del Banco Mundial, ya que el país había adquirido una importante deuda pública. 
Las medidas de gobierno más significativas de esta etapa se relacionan con la formulación de las siguientes leyes: para la continuación de la transferencia de los establecimientos educativos nacionales a las provincias $(24.048 / 93)$-proceso comenzado por la última dictadura militar-; la Ley Federal de Educación (24.195/94); la reforma constitucional de 1994 y la Ley de Educación Superior (24.521/95).

Frente a estos cambios, durante años los trabajadores de la educación llevaron adelante movimientos de fuerza que culminaron con la instalación de la Carpa Blanca en la Plaza de los Dos Congresos en pos de la mejora salarial, pero incluyendo el rechazo global a la reforma impulsada por el gobierno.

Según Adriana Puiggrós ${ }^{8}$, entre los problemas más destacables de estas políticas educativas deben señalarse:

- Desarticulación entre las provincias, en cuyos territorios coexistían tres y cuatro sistemas educativos distintos.

- Restricción de la oferta de nivel medio cerrando establecimientos y abriendo en menor cantidad secciones de polimodal.

- Ruptura del ciclo de enseñanza media como consecuencia de la inclusión, en algunas provincias, de la Educación General Básica (EGB) en el mismo establecimiento o bien organizada como "escuela intermedia" en un local aparte.

- Cierre de las opciones diversas de enseñanza técnica.

- Eliminación de clases de idiomas.

- Transferencia de los profesores de un área de conocimiento a otra sin la capacitación adecuada.

- Falta de preparación de los directores de primaria para supervisar a profesores de media y de los docentes de nivel primario para atender a población adolescente.

8 Puiggrós, A., Sujetos, disciplina y currículum, en los orígenes del sistema educativo argentino, Buenos Aires, Editorial Galerna, 1990. 
- Deterioro de la educación de adultos, la educación especial y la educación artística, que fueron separadas del tronco central del sistema, adquiriendo el carácter de "regímenes especiales".

- Insuficiencia de la educación inicial y exclusión de la asistencia materno-infantil de la responsabilidad educativa pública.

- Analfabetismo escasamente atendido y admitido por las políticas oficiales.

- Desarrollo de políticas asistenciales para compensar las desigualdades provinciales, a través, por ejemplo, del Plan Social Educativo.

En definitiva, durante los gobiernos de Carlos Menem, se puede decir que se llevó a cabo la transformación educativa, cuyo proceso estableció nuevos criterios de gestión del sistema basados en los principios de autonomía y responsabilidad individual por los resultados educativos. En este marco, la escuela para las clases populares se caracterizó por el enfoque asistencial, la exclusión disciplinadora y el vaciamiento ideológico-pedagógico.

En 1999 asumió el gobierno el presidente Fernando De la Rúa, desde cuyo mandato se desplegó un plan educativo que continuaba respondiendo a los mismos intereses que los gobiernos anteriores.

Esto se evidencia en los lineamientos estructurados en el conocido libro Educación para todos ${ }^{9}$, escrito por el entonces ministro de educación Juan José Llach, Silvia Montoya y Flavia Roldán, cuyos argumentos son definidos por Puiggróss como neomalthussianos y neodarwinistas. En clave critica, Puiggróss explica que este texto hace referencia, por un lado, a la teoría del capital humano, definido como el conjunto de conocimientos, habilidades, actitudes y valores de los padres y, por otro,

Llach, J., Montoya, S. y Roldán, F., Educación para Todos, IERAL Regional Litoral, 1999. 
remite a la teoría del capital social entendido como la calidad de las relaciones sociales familiares que inciden en la educación de los hijos. Bajo estas perspectivas el rendimiento escolar dependería, exclusivamente, del tiempo, el ingreso y los gustos de los padres respecto de la educación de sus hijos, así como de condiciones genéticas de los/as niños/as heredadas de los padres. Entre otras propuestas contenidas en Educación para todos, se destacan también las "escuelas chárter" y los "vouchers", formas típicas de la educación regida por el mercado.

Sucediendo diversos ministros de educación, en un clima marcado por los problemas financieros que paralizaban la gestión y la crisis política y social que estalló en marzo del 2000, el 20 de diciembre del 2001 renunció el presidente Fernando De la Rúa, hecho que representó un punto de inflexión en el proceso histórico nacional.

En conclusión, durante esta etapa se mantuvo una perspectiva en las políticas educativas signada por procesos de individuación que desplazaron la idea de derecho por la de beneficio; con una visión que define al "otro" como pobre, asociado a la pasividad y a la incapacidad, al mismo tiempo que promueve la construcción de su identidad como receptor y eterno deudor del Estado.

Las retóricas sobre la contención hacia las clases populares no alteraron los núcleos duros de la reproducción de la desigualdad social, porque estas políticas asistencialistas requerían para su funcionamiento de la existencia y permanencia de "alumnos pobres". Según Redondo "en la trampa integradora de la asistencia, en la vulnerabilidad como frontera o pasaje hacia la exclusión, se constituyen sujetos sujetados a la privación pero también sujetos deseantes de otros futuros"10. En este punto se establecen divergencias entre políticas de inserción-equidad o integración-inclusión: en un caso son un paliativo, en el otro

10 Redondo, P., "Infancia(s) latinoamericana(s), una deuda interna, un debate pendiente", Clase XXI, Diploma superior infancia, educación y pedagogía, Cohorte 1, FLACSO Virtual, 2014, pág. 13-14. 
abren, como se verá a continuación, una perspectiva ciudadana.

Hacia el enfoque de derechos: continuidades y rupturas con la etapa neoliberal

A partir del 2003 se pueden reconocer cambios en la relación sociedad-Estado, ya que las políticas públicas van centrándose en el enfoque de derechos. Estos avances significaron un papel más activo del Estado en el campo de las políticas públicas y también de la sociedad civil y sus organizaciones que interpelaban al campo estatal.

Dentro de las políticas propiamente educativas, la educación es considerada como un bien público y como un derecho social, donde el Estado debe ser el garante central, tal como se expresa en algunos ejemplos posteriores.

Un acontecimiento importante que refiere al cambio de perspectiva, se relaciona con la declaración de la Asignación Universal por Hijo (AUH) ${ }^{11}$, muy significativa respecto a las políticas educativas para las clases populares. La AUH fue establecida por el Decreto 1602/09 del Poder Ejecutivo Nacional en cumplimiento con lo enunciado en el artículo 26 de la Ley 26.061/2005. Según fuentes del Ministerio de Educación, para el 2009, se incrementó la matricula en ciento veinte millones de estudiantes como efecto de la medida.

En definitiva, la AUH habilita la asistencia y permanencia de niños, niñas y adolescentes de clases populares en la escuela, a la vez que impacta en las condiciones objetivas de estos grupos, porque uno de sus objetivos es que éstos y éstas se realicen

11 La AUH constituye una prestación monetaria no contributiva destinada a niñas, niños y adolescentes, cuyos adultos responsables se encuentran desocupados, trabajan en el mercado informal o son empleados en servicio doméstico y perciben un ingreso igual o menor al salario mínimo vital y móvil. 
controles periódicos de salud y cumplan con el calendario de vacunación obligatorio. Como dice Gustavo Galli:

La AUH ya abrió la puerta de las escuelas. No invitó, hizo pasar. No enunció un derecho, lo otorgó. Lo que viene de este desafío con que se encuentra la escuela puede ser comprendido como uno de los más complejos. La reforma no es ahora del sistema, es de paradigmas, los cambios son de concepciones de escuela, una escuela para todos es para todos. $^{12}$

Asimismo, durante el período 2003-2007, se sancionaron diversas leyes que impactaron en la temática de estudio, entre ellas: Ley de Garantía del Salario Docente y 180 Días de Clase $\left(\mathrm{N}^{\circ}\right.$ 25.864, año 2003); Ley del Fondo Nacional de Incentivo Docente ( $\mathrm{N}^{\circ}$ 25.919, año 2004); Ley de Educación Técnico Profesional $\left(\mathrm{N}^{\circ}\right.$ 26.058, año 2005); Ley de Financiamiento Educativo $\left(\mathrm{N}^{\circ}\right.$ 26.075, año 2005); Ley Nacional de Educación Sexual Integral $\left(\mathrm{N}^{\circ} 26.150\right.$, año 2006); y Ley de Educación Nacional ( $\mathrm{N}^{\circ} 26.206$, año 2006). ${ }^{13}$

Estas legislaciones, y específicamente la Ley de Promoción de la Convención y el Abordaje de la Conflictividad Social en las Instituciones Educativas ( $\left.\mathrm{N}^{\circ} 26.892\right)$, evidencian algunas rupturas frente al consenso reformista neoliberal de los 90 , ya que algunas de sus prioridades son cumplir con los artículos 28 y 29 de la Convención Internacional de los Derechos del Niño, donde se recomienda que el Estado:

\footnotetext{
12 Gall, G., Escuela secundaria y educación popular: cartografía de una experiencia, Buenos Aires, Editorial Stella, La Crujía, La Salle, 2014, pág. 34.

13 Entre otras medidas, para la normalización y democratización del sistema educativo, se pueden nombrar: la creación del Instituto Nacional de Formación Docente; el Observatorio de Violencia en la Escuela; el Programa Mediación en la Escuela; el Plan de Finalización de Estudios Primarios y Secundarios (FINES) para la terminación escolar primaria de mayores de 18 años; el Programa de Inclusión/Terminalidad de la Educación Secundaria para jóvenes de 14 a 17 años; los sistemas de becas estudiantiles como el Programa de Respaldo a Estudiantes Argentinos (PROGRESAR), el Programa Nacional de Becas Universitarias (PNBU) y el Programa Nacional de Becas Bicentenario (PNBB); el programa Jóvenes con Más y Mejor Trabajo; la revalorización de aéreas históricamente postergadas como la educación rural, la formación artística, la enseñanza intercultural bilingüe; la creación de diversas universidades, situadas contiguas entre sí, cuya necesidad es discutida por algunos expertos; entre otras cuestiones menos importantes.
} 
Aumente el presupuesto asignado a la educación. Aplique el Plan Social de Educación para asegurar la asistencia escolar regular y la reducción de las tasas de deserción escolar, especialmente entre los niños más vulnerables. Fortalezca los programas de subsidios y becas para los niños más afectados por la crisis económica.

Fortalezca y expanda la educación sobre los derechos humanos y de los niños.

Mejore la calidad de la educación para alcanzar los objetivos mencionados.

En el 2005 la Ley $N^{\circ} 26.075$ de Financiamiento Educativo -con vigencia a partir del año 2006- estableció entonces un horizonte de recursos, una división de compromisos entre el gobierno nacional y los provinciales y los instrumentos institucionales para garantizar los siguientes objetivos, los cuales tienen alcance para la educación inicial, primaria, secundaria y superior:

Incluir en el Nivel Inicial al $100 \%$ de la población de 5 años y asegurar la incorporación creciente de los niños y niñas de 3 y 4 años, priorizando a los sectores sociales más desfavorecidos.

Garantizar un mínimo de 13 años de escolaridad obligatoria para todos los niños, niñas y jóvenes. Asegurar la inclusión de los niños, niñas y jóvenes con 'necesidades educativas especiales'. Lograr que, como mínimo, el 30\% de los alumnos de educación básica tengan acceso a escuelas de jornada extendida o completa, priorizando los sectores sociales y las zonas geográficas más desfavorecidas.

Avanzar en la universalización del Nivel Medio logrando que los jóvenes no escolarizados ingresen o se reincorporen y completen sus estudios.

Erradicar el analfabetismo en todo el territorio nacional.

Producir las transformaciones pedagógicas y estructurales que posibiliten mejorar la calidad y equidad del sistema educativo nacional en todos los niveles y modalidades, garantizando la apropiación de los núcleos de aprendizaje prioritarios por parte de todos los alumnos de todos los niveles. Expandir la incorporación de las tecnologías de la información y de la comunicación en los establecimientos educativos y extender la enseñanza de una segunda lengua.

Incrementar la inversión en infraestructura y equipamiento de las escuelas y centros de formación profesional.

Mejorar las condiciones laborales y salariales de los docentes de todos los niveles del sistema educativo, la jerarquiza- 
ción de la carrera docente y el mejoramiento de la calidad en la formación docente inicial y continua. ${ }^{14}$

Fortalecer la democratización, la calidad, los procesos de innovación y la pertinencia de la educación brindada en el sistema universitario nacional.

Jerarquizar la investigación científico-tecnológica.

Establecer criterios técnicos que comprometan que las provincias con menor gasto por alumno mejoren el desempeño en ese indicador. ${ }^{15}$

Como se destaca en el segundo punto, bajo el artículo 28, la Ley de Educación Nacional establece la extensión de la jornada escolar a seis horas para las escuelas primarias. Este espacio curricular es impulsado según ciertas particularidades de cada provincia, priorizándose el acceso de los sectores sociales y las zonas geográficas más vulnerables. Otras características sobre jornada extendida, espacio en el cual se inserta la investigación, se ampliarán en otro capítulo.

Asimismo, la Ley de Financiamiento Educativo crea el Programa Nacional de Compensación Salarial Docente, cuyo objetivo es “contribuir a la compensación de las desigualdades en el salario inicial docente en aquellas provincias en las cuales [...] no resulte posible superar dicha desigualdades". ${ }^{16}$

Para la capacitación docente y la planificación de propuestas pedagógicas, se encuentran: el Plan de Formación en Servicio para Maestros y Maestras de Escuelas Primarias-Recuperación del Saber Docente y Redes de Maestros; el Programa Nacional de Formación Permanente Nuestra Escuela; el Programa de Desarrollo Profesional de Equipos de Orientación; el Plan de Formación de Supervisores y Directores y el Programa de Fortalecimiento y Mejora de los Sistemas de Gobierno-Políticas Intersectoriales para la Niñez.

\footnotetext{
14 El salario docente mejoró en gran medida en este periodo, ya que entre el 2004 y el 2010 las remuneraciones reales de maestros y profesores con diez años de antigüedad mejoraron su nivel de compra en el 73,7\% y el 62,5\%, respectivamente (Kessler, 2014).

15 Estos datos se extraen del documento Tercer Informe Periódico de la Convención sobre los Derechos del Niño, en virtud de su artículo 44, Secretaria Nacional de Niñez, Adolescencia y Familia, Ministerio de Desarrollo Social, Presidencia de la Nación, 2008.

16 Fragmentos extraídos de la Ley de Financiamiento Educativo $\mathrm{N}^{\circ} 26.075$, artículo 9 , 2005.
} 
Otra dimensión fundamental en este proceso se vincula con la necesidad de establecer una estructura educativa común. A cada nivel de educación le corresponden entonces ciertos Núcleos de Aprendizajes Prioritarios (NAP). Así, se sostiene un trabajo cuyo objetivo es garantizar condiciones de igualdad educativa "construyendo unidad sin uniformidad y rescatando la función pública de la escuela" de manera que "todos los habitantes alcancen competencias, capacidades y saberes equivalentes con independencia de su ubicación social y territorial". ${ }^{17}$ Sobre la base de los NAP, el Ministerio de Educación elaboró la serie de libros Cuadernos para el Aula, una colección de textos para la educación inicial, primaria y secundaria, con herramientas que orienten el trabajo docente mediante propuestas de enseñanza en el aula desde distintos campos de conocimiento.

En el marco de democratizar el acceso al conocimiento, adquiere importancia la incorporación de las tecnologías en los procesos pedagógicos y administrativos. En este punto, se crea el Programa Conectar Igualdad, tendiente a la inclusión digital a través de la entrega de netbooks a alumnos, docentes y/o escuelas públicas y de educación especial; junto con el desarrollo de contenidos digitales para propuestas didácticas. A su vez, se formó la plataforma Educ.ar donde aparecen contenidos pedagógicos para ser trabajados en la escuela, lo cual es acompañado por canales de televisión educativos (Encuentro), de ciencia y tecnología (Tecnópolis) y para niños/as (Pakapaka).

En cuanto a la mejora en infraestructura escolar, se parte de reconocer que la distribución igualitaria de los bienes materiales también es un pilar fundamental para el cumplimiento de los derechos educativos. Para llevar adelante las obras, se trabajó de manera conjunta con los ministerios provinciales, luego de un proceso de selección de las escuelas a construir o reconstruir, a través de políticas como Plan Obras, Proyecto de Provisión de Servicios Básicos, Obras de Emergencia, el Programa Nacional 700 Escuelas, entre otros.

$17 \quad$ Fragmentos extraídos del documento Núcleos de Aprendizajes Prioritarios, Segundo Ciclo de Educación Primaria: $4^{\circ}, 5^{\circ}$ y $6^{\circ}$ años, Ministerio de Educación, Presidencia de la Nación. 
También en esta nueva etapa, se despliegan varias políticas socio-educativas para el nivel primario, en pos del fortalecimiento de las trayectorias educativas y los vínculos con la comunidad. Bajo este eje, por ejemplo, los Centros de Actividades Infantiles (CAI) ${ }^{18}$ ofrecen a los/as niños/as la posibilidad de participar en actividades culturales, tecnológicas, deportivas y recreativas como una forma de inclusión social e integración ciudadana.

En lo que refiere específicamente a políticas destinadas para la asistencia, permanencia y calidad educativa, se produjeron diversos programas, por lo cual se mencionarán a continuación los más significativos para el nivel primario, que representa el eje de esta investigación.

El Programa Nacional de Inclusión Educativa (PNIE) busca dar respuesta a la exclusión escolar de un sector de niños/as -también adolescentes- que han quedado fuera de los circuitos educativos del sistema a causa del deterioro socioeconómico de las últimas décadas.

El PNIE propone un modelo de trabajo entre distintos niveles organizacionales (nacional, jurisdiccional y territorial-local). En las Mesas de Coordinación Nacional, Provincial y Local se llevaban a cabo proyectos de inclusión organizados en una línea pedagógica denominada "espacio puente", en los cuales se recibe a los/as niños/as y jóvenes que se encuentran fuera del sistema, mediante talleres de arte, clases de apoyo escolar, emprendimientos productivos, tutorías y otros. ${ }^{19}$

Otra política pública educativa que apunta a la justicia e igualdad educativa para el mejoramiento de las condiciones de enseñanza y aprendizaje, formando parte de las condiciones obje-

18 En el caso de las políticas socio-educativas para jóvenes se desarrollan los Centros de Actividades Juveniles (CAJ).

19 Para las infancias, el PNIE organiza: el programa Volver a la Escuela, para niños y niñas que no hayan cursado el año anterior a la inscripción al programa; PNIE Rural, para niños/ as que no hayan finalizado la escuela primaria en escuelas rurales aisladas; PNIE Judicializados, para niños, niñas y en este caso jóvenes, que por causas sociales o penales están bajo tutela judicial. 
tivas de la escuela del barrio en estudio, es el Programa Integral para la Igualdad Educativa (PIIE).

Más allá de que en otro capítulo se examinarán específicamente las condiciones objetivas de la escuela, para contextualizar resulta importante mencionar primeramente que el PIIE es un programa creado en el 2004, como intervención hacia las escuelas urbanas de mayor vulnerabilidad y se define como una propuesta transversal que busca sostener políticas comunes para todo el nivel primario. El programa propone la diagramación de una iniciativa o proyecto pedagógico y para su implementación ofrece capacitación y acompañamiento pedagógico y otorga un subsidio para cada institución.

Respecto a programas educativos presentes en la provincia de Córdoba, que impactan en las escuelas de nivel primario, se pueden nombrar: el Programa Provincial Más y Mejor Escuela que prevé la ampliación de la infraestructura escolar y apoyo a la educación en contextos de pobreza, mediante la distribución de materiales escolares y capacitaciones docentes; el Programa de Fortalecimiento Administrativo para Escuelas, que incorpora herramientas tecnológicas en el proceso administrativo escolar; la Red Provincial de Formación Docente Continua, con el objetivo de garantizar el acceso a diversas propuestas de capacitación profesional; los Equipos Profesionales de Apoyo Escolar (EPAE); entre otros.

Asimismo, la provincia de Córdoba y, particularmente, la escuela del barrio analizado, cuentan con el Programa de Asistencia Integral de Córdoba (PAICOR) destinado a garantizar la alimentación de la población en edad escolar en situación de pobreza o indigencia.

Ahora bien, en función de estas políticas públicas -nacionales y provinciales- que posibilitan el acceso y permanencia de los/ as niños y niñas en la escuela, es fundamental plantear como interrogante qué sucede en las escuelas en contextos populares con las formas de transmisión del capital escolar, porque en el marco de haberse modificado -en parte- las condiciones objeti- 
vas es necesario también que cambien las prácticas escolares a nivel micro social.

Así este interrogante abre un campo de disputas; según el Programa Internacional de Evaluación de los Alumnos (PISA), en 2011, de sesenta y cinco países en América Latina, Argentina obtuvo el puesto cincuenta y ocho como peor rendimiento educativo. Bajo estos análisis, se sostiene que los/as alumnos/ as del estrato social más bajo presentan los peores resultados escolares. Entre los argumentos de la baja calidad educativa, se mencionan las desigualdades socioeconómicas y las fallas del funcionamiento del sistema, por ejemplo, dado la menor cantidad de clases por año que reciben los sectores populares por las lógicas "flexibles" de las instituciones y los déficits en la capacitación de los docentes que albergan estas escuelas ${ }^{20}$. Sin embargo, hay que tener presente la ilusión numérica y descontextualizada que puede traer aparejada este indicador de "calidad educativa”. Lo que es necesario asegurar son las condiciones materiales y simbólicas democráticas para todas las escuelas $y$, a su vez, es fundamental problematizar qué y cómo se quiere enseñar en los contextos de vulnerabilidad, para habilitar en los niños y las niñas de clases populares la apropiación de bienes socialmente significativos, en pos de una activa participación ciudadana.

Tensiones entre condiciones estructurales y prácticas institucionales

Lo que se intentó exponer en este apartado introductorio, situando procesos en un periodo especifico, es que si bien lo legal amplía el horizonte de lo pensable respecto a otras épocas y proyectos de Estado, no se puede asegurar que esto se haya traducido -hasta el momento- en cambios significativos de representaciones y prácticas en los agentes institucionales encarga-

20 Kessler, G., Controversias sobre la desigualdad: Argentina 2003-2013, Cuidad Autónoma de Buenos Aires, Fondo de Cultura Económica, 2014. 
dos de la aplicación de las respectivas políticas públicas. Según Valeria Llobet:

[...] los derechos son efectivos en y a través de prácticas sociales, en contextos particulares y en marcos temporales, y por ello no necesariamente siempre tienen el mismo significado [...] las consecuencias de los 'usos' particulares de los derechos de los niños no necesariamente coincidirán con sus objetivos iniciales [...]. ${ }^{21}$

En función con el objeto de esta investigación, reconstruir las condiciones objetivas que se tensionan con las estructuras simbólicas supone analizar las representaciones que circulan en los dispositivos escolares para problematizar cómo en la escuela se transmite y distribuye el capital escolar con respecto a las infancias de clases populares. La autonomía relativa de las estructuras simbólicas ocasiona que varias de las percepciones de los agentes institucionales de la escuela del barrio sigan nucleadas en el sistema de sentido de la pobreza, propio del contexto neoliberal.

$21 \quad$ LLOBEt, V., “Las políticas para la infancia y el enfoque de derechos en América Latina: algunas reflexiones sobre su abordaje teórico”, Revista de Psicología, n³, 2011. 


\section{CAPÍTULO II \\ Representaciones y prácticas de los agentes institucionales}



Estos chicos no tienen límites, ellos andan libres por la calle, pero cómo les vas a enseñar andar por la vereda si habrás notado que no hay vereda en el barrio, entonces es muy difícil enseñarles cualquier cosa (...). ${ }^{1}$

Desde la teoría estructural-genética de Pierre Bourdieu, se sustituye la falsa antinomia entre subjetivismo y objetivismo por la dialéctica entre los dos modos de existencia histórica de lo social: las estructuras sociales externas, lo social hecho cosas, plasmado en las condiciones objetivas; y las estructuras sociales internalizadas, lo social hecho cuerpo. El concepto de campo -lo social externo- y el de habitus -lo social internalizado- posibilitan explicar y comprender las prácticas y representaciones de los agentes sociales.

En este sentido las prácticas de los agentes ni son acciones completamente determinadas, ni el resultado de la elección es libre e individual; sin embargo suponen intencionalidad sin intención estrictamente consiente, como regularidad sin sumisión a la regla y racionalidad sin cálculo. De este modo, el sujeto de la práctica no es una esencia, se va haciendo en el marco de relaciones de fuerza y de sentido, cuyo sistema de relaciones construye el investigador posicionado al sujeto como agente epistémico.

Por su parte, se conceptualiza a las representaciones a partir de los esquemas cognitivos e incorporados por los agentes -habitus- en las relaciones producidas por la estructura social. Se puede decir que "las representaciones sociales [son] aquellas construcciones de sentido que son producidas por los sujetos en base a una conciencia práctica del mundo cotidiano, sus objetos y las posibilidades que en él aparecen"2.

Para explicar y comprender prácticas y representaciones hay que "situarlas" en el espacio y el tiempo bajo los cuales se desarrollan, es decir, para encontrar los principios explicativos

Nota de campo 2, 8-05-2014.

2 ZanotTI, A., Jóvenes y trabajo en sectores populares: representaciones, trayectorias y habitus, Villa María, Eduvim, 2010. 
de las prácticas y discursos hay que reconstruir y construir las nociones de campo y habitus, respectivamente.

Ambos conceptos, campo y habitus, son relacionales en el sentido que se comprenden uno con el otro:

[...] la relación entre el habitus y el campo es, ante todo, una relación de condicionamiento: el campo estructura el habitus, que es producto de la incorporación de la necesidad inminente; pero es también una relación de conocimiento o construcción cognitiva: el habitus contribuye a construir el campo como mundo significante, dotado de sentido. ${ }^{3}$

El habitus, como principio generador de prácticas y representaciones, se encuentra inscripto o se actualiza dentro de una libertad limitada. Siendo producto de la historia y no del destino, es un sistema abierto de disposiciones perdurables pero no inmutables.

La lógica de los habitus de clase -originados en la historia individual y colectiva-encuadra diferencias entre los grupos según las percepciones y disposiciones a actuar más de una manera que de otra. Esto varía en función de la trayectoria y posición de los agentes en el mundo social -cuya adaptación no supone la búsqueda consciente de los fines objetivos del campo-, desde dónde se incorporan los esquemas de conocimiento, legitimándose las divisiones sociales entre "lo que es para nosotros" y "lo que no es para nosotros", "lo pensable" y "lo impensable", esquemas clasificatorios que se naturalizan porque funcionan "en la práctica y para la práctica”.

Como estructura estructurante -también estructurada- el habitus se entiende entonces como un conjunto de esquemas de percepción, apreciación y acción, que permite llevar a cabo actos de conocimiento práctico:

[...] el habitus [...] genera prácticas 'razonables' y no 'racionales' [...] es decir es un conocimiento práctico que se va adqui-

3 BouRdieu, P. Y WACQUANT, L., Respuestas por una antropología reflexiva, Op.cit., pág.102103. 
riendo en el proceso de socialización, que permite actuar como si se conociera el mundo y las formas de moverse en él, que lleva a que se desarrollen estrategias dentro de los limites de las imposiciones estructurales [...]. ${ }^{4}$

En definitiva, el habitus imprime "razonabilidad" a las definiciones provenientes del sentido común.

Por lo antes dicho, las prácticas y representaciones se pueden comprender desde las experiencias propias de los agentes sociales y se pueden explicar a partir de los puntos de vista asumidos desde las diferentes posiciones -que suponen relaciones entre posiciones- inscriptas en el tiempo social que sostiene a las trayectorias individuales y de clase, por el cruce entre el pasado, el presente y lo esperado.

Desde aquí es posible establecer la correlación entre una determinada práctica y el origen social, resultante del efecto de inculcación -condiciones de existencia originales- y el efecto de trayectoria social propiamente dicho. El efecto de trayectoria impone la representación de la posición ocupada en el mundo social y la visión de este mundo y su porvenir; en función del origen social, la trayectoria va definiendo la pendiente de la carrera social. ${ }^{5}$

Como los agentes están posicionados estructuralmente y a su vez son percibidos socialmente, se establecen tensiones en las percepciones en y entre las clases o fracciones de clases; es decir, "una clase se define por su ser percibido tanto como por su ser". 67

\footnotetext{
Pavcovich, P., Juanito laguna va a la escuela: la educación popular desde la sociología de Pierre Bourdieu, Villa María, Córdoba, Eduvim, 2010, pág. 130-131.

5 Bourdieu, P., La distinción. Criterios y bases del gusto, Madrid, Taurus, 1979.

6 Bourdieu, P., La distinción. Criterios y bases del gusto, Madrid, Taurus, 1979, pág. 494.

7 Para la construcción de los actos enclasables, se retoma el principio de la vigilancia epistemológica o ruptura epistemológica explicado por Bourdieu en El oficio de sociólogo: presupuestos epistemológicos (1975), que exige una explicitación metódica de los principios de la construcción del objeto. La vigilancia epistemológica se distingue del análisis homogéneo, temporalmente lineal y descontextualizado de las prácticas de los agentes, mediante "la objetivación de la relación objetiva y subjetiva con el objeto" (BouRDIEU, P., El sentido práctico, Madrid, Taurus, 1994, pág. 9).
} 
Las clases objetivas representan al conjunto de agentes que se encuentran situados en condiciones de existencia homogéneas que, a su vez, producen unos sistemas de disposiciones más o menos homogéneas. Estos grupos producidos por los principios de división social, incorporan las jerarquías que están presentes en los objetos, en las instituciones -para este caso, en el sistema escolar-, en los movimientos del cuerpo ${ }^{8}$ y en el lenguaje; son "llamadas al orden" que se interiorizan progresivamente. Es lo que Bourdieu define como: por un lado, actos de enclasamiento, bajo los cuales los agentes se posicionan según el sentido de los límites hechos cuerpo y pensamiento, asegurando lugares comunes y distancias sociales en y entre los grupos. Por otro, actos enclasados, originados desde los juicios de atribución o juicios de acusación y desde la lógica del estigma ${ }^{9}$ que funcionan en las divisiones entre "nosotros" y "ellos". Es por esto que los sistemas de enclasamiento son principios orientadores de las prácticas.

La tarea del investigador es objetivar estas prácticas -y las que él mismo compromete en el acto de conocer- agrupando objetivamente a las clases, como principios explicativos de las prácticas, mediante la noción de campo social. El campo posibilita construir un sistema de posiciones que agrupa relacionalmente

\footnotetext{
Para el tratamiento del material empírico, se debe tener presente que los instrumentos de medición, las categorías y en general todas las operaciones de la práctica sociológica son teorías en acto, que permiten reconstruir el sistema de relaciones en el cual los individuos se hallan insertos, no aludiendo meramente a las prenociones del investigador $\mathrm{y} / \mathrm{o}$ a las opiniones declaradas por los sujetos, ya que, "se pueden y se deben, sin duda, recoger los discursos más irreales, pero a condición de ver en ellos no la explicación del comportamiento sino un aspecto del mismo que debe explicarse" (Bourdieu, P., Chamboredon, J., Y Paseeron, J.c., El oficio de sociólogo: presupuestos epistemológicos, Buenos Aires, Siglo Veintiuno Editores, 1975, pág. 58).

8 La hexis corporal es la manera práctica de experimentar y expresar la opinión que se tienen sobre el propio valor social, que es lo mismo que decir el lugar ocupado con el cuerpo en el espacio físico-social.

9 "Lo lógica del estigma recuerda que la identidad social es la apuesta de una lucha en la cual el individuo o grupo estigmatizado y, más generalmente, todo sujeto social, en tanto que es objeto potencial de categorización, no responde a la percepción parcial que lo encierra en unas de sus propiedades más que poniendo delante, para definirse, la mejor de ellas y, más generalmente, luchando por imponer el sistema de enclasamiento más favorable a sus propiedades o incluso para dar al sistema de enclasamiento dominante el contenido más adecuado para poner en valor lo que es y lo que tiene" (BOURDIEU, P., El sentido práctico, Op.cit., 486).
} 
a los agentes involucrados en el juego social que ese campo supone $^{10}$. Dichas posiciones se diferencian por la desigual distribución, control y apropiación de capitales eficientes, estructurándose intereses comunes en pugna. Hablar de capital eficiente significa que ese capital específico vale en relación con un campo determinado, es decir, dentro de los límites de este campo y que solo se puede convertir en otra especie de capital dentro de ciertas condiciones.

En otras palabras, campo podría definirse como:

[...] una red o configuración de relaciones objetivas entre posiciones. Estas posiciones se definen objetivamente en su existencia y en las determinaciones que impone a sus ocupantes [...] por su situación actual y potencial en la estructura de la distribución de las diferentes especies de poder (o de capital) y, de paso, por sus relaciones objetivas con las demás posiciones (dominación, subordinación, homología, etc.). ${ }^{11}$

Aquellos que, dentro de un determinado estado de las relaciones de fuerza, monopolizan -en ciertos grados- el capital especifico, que es el fundamento del poder característico de un campo, se inclinan hacia estrategias de conservación, mientras que los que disponen de menos capital -que suelen ser también los "recién llegados"- se inclinan a utilizar estrategias de subversión -las de la herejía- que están a menudo ligadas a crisis estructurales y obligan a los dominantes a elaborar discursos defensivos.

Por otro lado, las diferentes especies de capital que permiten construir el campo social general, como espacio de las clases sociales, son cuatro: el económico, el cultural, el social y el simbólico ${ }^{12}$. Estos constituyen el cuadro patrimonial de los

10 Costa, R., "La lógica de las prácticas en Pierre Bourdieu”, Current Sociology, vol. 54, SAGE Publications, Londres, 2006.

11 Bourdieu, P. y WaCquANt, L., Respuestas por una antropología reflexiva, Op.cit., 64.

12 Bourdieu distingue entonces: el capital económico, según la apropiación de bienes y servicios que son cotizados en el mercado; el capital social, que tiene que ver con la participación en una red durable de relaciones que permiten la posesión de otros capitales; el capital simbólico, que establece los criterios de lo valioso y lo permitido dentro de las relaciones sociales, por lo tanto, este capital sirve para imponerse en la lucha por las definiciones, dando sentido a lo real; y el capital cultural, que incluye tres formas, en el estado 
agentes sociales a partir de su volumen, estructura y trayectoria (acumulación y composición en el tiempo de estas propiedades, según el recorrido pasado y potencial de los agentes sociales en el espacio social).

En síntesis, estos sistemas de enclasamientos -objetivados en propiedades específicas, incorporados o institucionalizados-, bajo los cuales los individuos "se enclasan y enclasan a los demás", remiten a las relaciones en y entre los grupos y a los puntos de vista sobre el mundo que tienen los agentes de acuerdo al lugar ocupado en el espacio social. Estos esquemas clasificatorios y lugares comunes expresan formas de dominación y oposición, es decir, enuncian la división del trabajo entre las clases sociales y las clases de edades y los sexos.

Homologías entre el campo educativo y el campo social general

En el caso de la investigación, interesa reconstruir los puntos de vista de las educadoras de la escuela del barrio, comprendiendo sus prácticas de diferenciación -enclasadas y enclasantes- en relación a los niños y las niñas que asisten a la institución y a sus familias. Para analizar los procesos de transmisión del capital escolar se posiciona entonces a las docentes y directivos como agentes institucionales e interesa objetivar sus prácticas de acuerdo al lugar ocupado en el campo escolar.

En La reproducción. Elementos para una teoría del sistema de enseñanza, ${ }^{13}$ Bourdieu y Passeron analizan la homología existente entre el sistema de enseñanza y la estructura de clases, por medio de la cual se adaptan las prácticas escolares al funcionamiento y perpetuación de las jerarquías sociales:

incorporado (disposiciones duraderas del organismo), en el estado objetivado (posesión de bienes culturales) y en el estado institucionalizado (objetivación particular que le suministra a los agentes propiedades específicas y legitimadas formalmente).

13 BouRdieu, P. y PASSERON, J.c., La reproducción. Elementos para una teoría del sistema de enseñanza, México, Distribuciones Fontamara, S.A, 1996. 
[...] una teoría adecuada del habitus como lugar de interiorización de lo externo y exteriorización de lo interno, permite revelar completame nte las condiciones sociales del ejercicio de la función de legitimación del orden social que, de todas las funciones ideológicas de la escuela, es sin duda la mejor disimulada. ${ }^{14}$

Esta complicidad entre el sistema de enseñanza y el espacio de las clases sociales es posible porque la escuela, mediante específicas prácticas y discursos que aparecen como "neutrales", oculta el ejercicio de la violencia simbólica que eufemiza las relaciones de fuerza, en las que basa su propia fuerza. En otras palabras, la violencia simbólica se entiende como:

[...] coerción que se instituye por mediación de una adhesión que el dominado no puede evitar otorgar al dominante [...] cuando sólo dispone, para pensarlo y pensarse o, mejor aún, para pensar su relación con él, de instrumentos de conocimiento que comparte con él y que, al no ser más que la forma incorporada de la estructura de la relación de dominación, hacen que ésta se presente como natural [...]. ${ }^{15}$

Este poder simbólico es el poder de hacer, ver y creer de determinada manera; es un instrumento de conocimiento y comunicación:

A este efecto ideológico, la cultura dominante lo produce disimulando la función de división bajo la función de comunicación: la cultura que une (medio de comunicación) es también la cultura que separa (instrumento de distinción) y que legitima las distinciones constriñendo a todas las culturas (designadas como sub-culturas) a definirse por su distancia con la cultura dominante. ${ }^{16}$

Se sustenta así que las representaciones y prácticas pedagógicas de los agentes institucionales contribuyen a crear opinión, opción, sentimiento y palabra, es decir, posicionan jerárquicamente a los niños y las niñas que asisten a la escuela, en refe-

\footnotetext{
14 Bourdieu, P. y PASSERON, J.c., La reproducción. Elementos para una teoría del sistema de enseñanza, México, Distribuciones Fontamara, S.A, 1996, pág. 262.

15 Bourdieu, P., Meditaciones pascalianas, Op.cit., pág. 224.

16 Bourdieu, P., Intelectuales, política y poder, Eudeba, 1999b, pág. 68.
} 
rencia a su entorno, a sí mismos y a los demás. ${ }^{17}$ Las prácticas y discursos docentes van haciendo, de los niños y las niñas, cuerpos afectiva y cognitivamente socializados y disciplinados, mediante específicos ritos de institución:

[...] mediante los cuales los grupos se esfuerzan por inculcar los limites sociales o [...] las clasificaciones sociales [...] en naturalizarlas en forma de divisiones de los cuerpos, las hexis corporales, las disposiciones respecto a las cuales se entiende que son tan duraderas como las inscripciones indelebles del tatuaje, y los principios de visión y división colectivos. $^{18}$

Ahora bien, las prácticas y discursos pedagógicos son eficaces socialmente porque se respaldan en la autoridad pedagógica de quienes llevan a cabo las acciones pedagógicas, lo que también puede asociarse al arte de la distancia ${ }^{19}$, distancia que de profundizarse, a niveles en los que el reconocimiento entre las partes va obturándose, convierte a la acción pedagógica en un mito pedagógico. ${ }^{20}$

El discurso de autoridad de los agentes pedagógicos se caracteriza así por lo que Baquero, Diker y Frigerio, en Las formas de lo escolar, ${ }^{21}$ designan como discurso pedagógico neto, haciendo referencia al tipo de prescripción pedagógica que muestra como base de legitimación su carácter de "saber culto", supuestamente indiferente de las dimensiones políticas y sociales.

Asimismo, la autoridad pedagógica se articula con la delegación del derecho a la violencia simbólica por parte de los que sufren la inculcación. Aquí se enlazan dominación y legitimidad, lo cual no podría entenderse sin el reconocimiento de los dominados, que van aceptando -en parte- el orden social por el des-

\footnotetext{
17 Pavcovich, P., Juanito laguna va a la escuela: la educación popular desde la sociología de Pierre Bourdieu, Villa María, Córdoba, Eduvim, 2010.

18 Bourdieu, P., Meditaciones pascalianas, Op.cit., pág. 186.

19 RANCIÈRE, J., El maestro ignorante. Cinco lecciones sobre la emancipación intelectual, Buenos Aires, Libros del Zorzal, 2007

20 CRIADO, M.E., La escuela sin funciones. Crítica de la sociología de la educación crítica, España, Bellaterra, 2010

21 Baquero, R., Diker, G. y Frigerio, G. (compiladores), La Forma de lo escolar, Buenos Aires, Del Estante Editorial, 2007.
} 
conocimiento de la arbitrariedad objetiva en el cual se funda, “ignorancia" causada por el conocimiento práctico o consenso pre-reflexivo estructurado desde sus habitus, que van siendo escolarizados. Por tanto:

[...] la percepción primera del mundo es siempre un acto de conocimiento, que constituye un desconocimiento que implica la forma más absoluta de reconocimiento del orden social. Los dominados tienden de entrada a atribuirse lo que la distinción les atribuye, rechazando lo que le es negado [...] contentándose con lo que se les otorga [...] definiéndose como les dice el orden establecido, reproduciendo en el veredicto que hacen de sí mismos el veredicto que sobre ellos hace la economía. ${ }^{22}$

Los anteriores planteamientos sociológicos de Bourdieu, podrían unirse con lo que Freire $^{23}$ llama lógica del acostumbramiento, sumisión, cultura del silencio, extrañamiento de sí como clase o habitus del opresor, diversas maneras de nombrar los procesos de violencia simbólica mediante los cuales los agentes en posición subalterna naturalizan hechos de dominación -simbólica y material-legitimando las prácticas culturales y educativas dominantes.

Para la incorporación de las normas dominantes y los valores distintivos por parte de los/as alumnos/as, dentro del campo escolar, se requieren ciertas especificidades en el tiempo de la educación, conforme al trabajo pedagógico como trabajo de inculcación con duración suficiente para ir produciendo una formación duradera, o sea, un habitus secundario como interiorización de los principios de una arbitrariedad cultural capaz de perpetuarse una vez terminada la acción pedagógica escolar. Dicha arbitrariedad cultural se instituye en función de las proximidades o tensiones de clase entre el trabajo pedagógico primario y el trabajo pedagógico secundario, transmitido por la escuela en tanto trabajo pedagógico dominante.

22 Bourdieu, P., La distinción. Criterios y bases del gusto, Op.cit., pág. 482.

23 FreIRE, P., Pedagogía del oprimido, Buenos Aires, Siglo Veintiuno Editores, 2005. 


\section{ASPECTOS EPISTEMOLÓGICOS Y METODOLÓGICOS}

La construcción dialéctica del objeto: cartografiando a la escuela del barrio

Cuando salieron de comer y nos fuimos de la escuela, muchos de los/as niños/as preguntaron si se podían sacar los guardapolvos (...). ${ }^{24}$

Tal como se desarrolló antes, el eje del trabajo supone abordar como unidad de análisis las prácticas pedagógicas reproductoras de enclasamientos en niños/as de clases populares, tomando como unidad de observación a la escuela primaria de un barrio periférico de Villa María, Córdoba. Se analizan entonces los puntos de vista de los agentes institucionales de la jornada extendida, estructurados en función de sus posiciones y trayectorias en el espacio educativo.

Bajo estos conceptos se sostiene como hipótesis que los esquemas de acción y percepción de los agentes institucionales de la jornada extendida en la escuela del territorio en cuestión implican la reproducción de enclasamientos sociales, mediados por prácticas pedagógicas que vinculan mecánicamente a la pobreza como imposibilidad de producción simbólica. De este modo, en la escuela se transmiten pobres conocimientos para niños y niñas construidos como pobres sujetos de conocimiento.

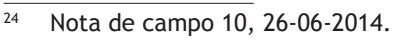


Desde la anterior hipótesis, los objetivos de la investigación involucran, por un lado, objetivar las condiciones de producción de las prácticas pedagógicas de los agentes institucionales de una escuela primaria situada en un barrio de clases populares. Por otro, resulta fundamental comprender la "razonabilidad" que significan los puntos de vista desde los cuales los agentes institucionales estructuran sus prácticas pedagógicas, imponiendo visiones y divisiones sociales con respecto a los niños, las niñas y familias del barrio.

En un nivel más especifico, la investigación que sostiene este libro, intenta re-construir las trayectorias en el espacio educativo de los agentes institucionales involucrados en la jornada extendida, así como analizar los sentidos que los agentes institucionales construyen sobre las estrategias de reproducción social de las familias del barrio e indagar sobre las significaciones que estructuran las interacciones entre los agentes institucionales y los alumnos y alumnas en la escuela.

Se recurre a la metáfora del mapeo o cartografía como herramienta de documentación y análisis que recupera las representaciones enclasantes, espacios, tiempos, en definitiva, las prácticas y las interacciones de los agentes en cuestión. De este modo, la escuela es un espacio, un "lugar practicado" que puede ser explicado, descripto y relatado.

\section{Al respecto, afirma De Certeau:}

El mapa [es] escena totalizante donde elementos de origen dispar se conjugan para formar el cuadro de un 'estado' de saber geográfico [...] los mapas exponen los productos del conocimiento, forman cuadros de resultados legibles [...] los relatos de espacio, por lo contrario, ejercen el papel cotidiano [...] función básica de autorizar el establecimiento, el desplazamiento o el rebase de limites [...] crean un campo que autoriza prácticas sociales arraigadas y contingentes. ${ }^{25}$

Al interpelar la frase anterior, para este caso, se enlaza la investigación con la intervención cotidiana en el espacio de la

25 De Certeau, M., La invención de lo cotidiano. I artes de hacer, Universidad Iberoamericana, Instituto Tecnológico y de Estudios Superiores de Occidente, 2000, pág. 134-140. 
escuela, y así se construye una cartografía que está atravesada por varias prácticas y relatos, incluso los propios, puestos en el mapa en clave problematizadora.

Al mapear el espacio de la escuela, este es re-interpretado, re-definido, según lo propio vivenciado, percibido y analizado, lo cual tensiona la subjetividad del "cartógrafo" que traduce. En este punto se introducen varias cuestiones epistemologías y metodológicas, propias de la elaboración del conocimiento científico.

Se toma como base la teoría de Pierre Bourdieu que supera la discusión entre sujeto y objeto, mediante la doble objetivación, problematizando la dimensión socio-histórica, el poder en las prácticas sociales y la agencia del sujeto.

Asimismo, para cartografiar la escuela, analizando los sentidos de las prácticas pedagógicas, se piensa a la institución conforme a la existencia de dispositivos áulicos e institucionales.

La noción de dispositivo, desde la perspectiva foucaultiana, refiere al análisis del poder estructurado entre lo discursivo y lo no-discursivo. Haciendo una breve lectura histórica de la obra de Foucault se puede decir que en el dispositivo se conjugan poder y saber. El dispositivo produce sentidos, prácticas e identidades excluyendo otras; tiene una dimensión estratégica, que implica reconocer de qué relaciones de poder-saber surge, y una dimensión táctica, que supone tener en cuenta qué efectos de poder-saber produce ${ }^{26}$, cuyas consecuencias negativas o positivas generan tensiones y reajustes. ${ }^{27}$

El dispositivo es "una especie de ovillo o madeja [...] está compuesto de líneas de diferente naturaleza [...] que siguen direcciones diferentes, forman procesos siempre en desequilibrio

26 Foucault, M., Historia de la sexualidad 1. La voluntad de saber, Siglo Veintiuno Editores, 1976.

27 CASTRO, E., El vocabulario de Michel Foucault: Un recorrido alfabético por sus temas, conceptos y autores, Buenos Aires, Universidad Nacional de Quilmes, 2006. 
[...] saber, poder y subjetividad son cadenas de variables relacionadas entre sí". 28

Esto quiere decir que el dispositivo está formado por líneas de fuerza, como relaciones de lucha por las definiciones, y líneas de subjetivación. En el dispositivo entonces se establece de qué se puede hablar -tabú del objeto-, en qué momento -ritual de las circunstancias- y quiénes -privilegio del sujeto-, aunque está atravesado por líneas de ruptura, de fisura, que se entrecruzan: "las líneas de subjetivación parecen especialmente capaces de trazar caminos que no cesan de abortar, pero tampoco de ser reanudados, modificados, hasta llegar a la ruptura del antiguo dispositivo". ${ }^{29}$

El dispositivo escolar instituye así conexiones entre elementos heterogéneos que regulan los tiempos, los espacios y las operaciones corporales de los sujetos, a través de la arquitectura, reglamentos, medidas administrativas, entre otras cuestiones. Disciplinar en la escuela es distribuir y controlar de un modo particular a los cuerpos de los/as alumnos/as en el espacio y en el tiempo.

Por otro lado, se retoman los conceptos de Patricio Bolton respecto a la matriz de aprendizaje institucional, la transversalidad de lo escolar y la red de sentidos. En su texto Educación y vulnerabilidad: experiencias y prácticas del aula en contextos diferentes, define a la matriz de aprendizaje institucional como currículum amplio, como la identidad o cultura institucional, más o menos narrada pero siempre actuada, que contiene rutinas, ritmos, mitos, representaciones, cierta división del trabajo, especificidades en la arquitectura -según las significaciones asociadas a los lugares- y lo imprevisto escolar.

De este modo, se educa con la propuesta explicita pero también con todo lo no explicito, a lo cual se denomina currículum oculto. Este refiere a los aprendizajes, normas, clasificaciones

\footnotetext{
28 Deleuze, G., “¿Qué es un dispositivo?”, en Deleuze, G., Glucksmann, A., Frank, M. y Balbier, E., Michael Foucault, filósofo, Gedisea, 1990, pág. 155.

29 Ibídem, pág. 159.
} 
sobre sí mismo y los "otros", incorporados por los estudiantes que no son deliberadamente seleccionados por los educadores y sin embargo son transmitidos por ellos:

Al igual que la cultura, debemos ver al currículum como una práctica de significación, como un texto, como una trama de significados; el currículum puede ser analizado como un discurso, como una práctica discursiva. Y como práctica de significación, el currículum así como la cultura, es sobre todo, una práctica productiva. ${ }^{30}$

Por su parte, la transversalidad de lo escolar refiere a los dispositivos pedagógicos o didácticos, según estilos pedagógicos y metodológicos, es decir, qué y cómo se enseña-aprende en la escuela, dado las disposiciones, apreciaciones y tomas de posición de los agentes institucionales, lo cual plasma redes de sentidos, en tanto espacios curriculares.

Analizar los contratos didácticos permite examinar las relaciones entre agentes institucionales y alumnos/as, según la intencionalidad y la significatividad de la práctica docente y la explicitación -o no- del proceso de enseñanza-aprendizaje hacia el alumno o alumna.

\section{Todas estas categorías representan:}

[...] una orientación ética que atraviesa las prácticas [...] No es neutral la selección de valores que la escuela decide mirar y reconocer. No es lo mismo felicitar el esfuerzo individual y asilado que el esfuerzo individual al lado del trabajo colectivo [...] son elementos cargados de una concepción del hombre, del conocimiento, del mundo, de la trasformación, del educador, del acto educativo que atraviesa todo lo que hacemos. ${ }^{31}$

Para re-construir o cartografiar la transversalidad de lo escolar y la red de sentidos, resultan significativos también los aportes de Martin Criado ${ }^{32}$ y su concepto de gramáticas de escolaridad,

\footnotetext{
30 DA SILVA, T., “Cultura y currículum como prácticas de significación”, Revista de Estudios del currículum, $\mathrm{n}^{\circ}$ 1, vol. 1, Pomares Corredor, 1998, pág. 68.

31 Bolton, P., Educación y vulnerabilidad: experiencias y prácticas del aula en contextos diferentes, Buenos Aires, Editorial Stella, CELADEC, La Crujía, 2006, pág. 79.

32 CRIADo, M.E., La escuela sin funciones. Crítica de la sociología de la educación crítica, España, Bellaterra, 2010.
} 
ya que permite reconocer los estilos pedagógicos teniendo en cuenta las variables de instrucción - "objetivo oficial”-, el control -necesario para instruir-y el examen -campo documental que selecciona y clasifica a los/as alumnos/as, a su vez que castiga los grados de "desviaciones" respecto al desempeño esperado-; variables que se cambian en función de las lógicas de determinadas instituciones escolares.

Es así que toda práctica pedagógica se estructura en la relación entre el educador y el educando, en un espacio y tiempo particular. La escuela establece principios de enmarcamiento ${ }^{33}$, es decir, hay reglas de realización y reconocimiento del poder de la cultura legítima, categorías de lo pensable y lo realizable, que sin embargo siempre pueden ser tensionadas por relaciones de resistencia, conflicto, traducción e innovación.

\section{Métodos y técnicas}

El diseño metodológico -explicativo y comprensivo- que estructura este libro, utiliza la triangulación inter e intra metodológica para abordar la dimensión objetiva y comprensiva de la temática, lo cual involucra metodologías cualitativas y cuantitativas. La investigación supone de este modo, explicar y -específicamente- comprender, prácticas sociales de enclasamiento social estructuradas en la escuela.

En Bourdieu la comprensión implica construir la "razonabilidad" que significan los puntos de vista desde los cuales los sujetos interpretan su posición y las relaciones con las que oponen posiciones. En conexión con lo anterior, explicar supone reconstruir las relaciones de fuerza que condicionan las disposiciones y tomas de posición de los agentes en el espacio social, según la posesión de capitales y sus trayectorias. Este tipo de análisis combina lo diacrónico y lo sincrónico y lo estructural y la acción

33 BeRnSTEIn, B., La estructura del discurso pedagógico. Clases, códigos y control (Volumen IV), Madrid, Ediciones Marota S.L, 1990. 
social, abordando las condiciones estructurales objetivas que operan como límite y las condiciones estructurales subjetivas que significan margen de posibilidad en el que los agentes sociales evalúan inversiones prácticas en sus vidas cotidianas.

Explicando y comprendiendo las prácticas y representaciones de los agentes sociales atravesadas por la dimensión del poder -teoría general-, cuyas relaciones adquieren especificidades en el campo escolar -teoría sustantiva-, las prácticas y puntos de vista de los agentes institucionales de la escuela del barrio en referencia a los niños, las niñas y a sus familias -regularidad empírica-, se reconstruyen desde diversos pasos metodológi$\cos ^{34}$

Lo primero es delimitar la configuración social desde la cual se va estudiar al campo escolar, según las significaciones de las prácticas pedagógicas de las educadoras de la escuela. Entonces, para construir las condiciones objetivas del barrio en el que se halla la institución escolar, se retoma el concepto de espacio social reificado, como parte del diseño teórico-metodológico, entendiendo al territorio como "la distribución en el espacio físico de diferentes especies de bienes y servicios y también de agentes individuales y grupos localizados físicamente y provistos de oportunidades [...] de apropiación de esos bienes y servicios" 35 . Desde las dimensiones de heterogeneidad, conflictividad, desigualdad, historicidad y poder $^{36}$ sobre el espacio físico-social, se problematizó la base de datos ${ }^{37}$ que se posee sobre el barrio -producto de un censo poblacional realizado en el marco del proyecto de investigación "Prácticas de sectores populares en contextos de pobreza", antes mencionado-, reconociendo las diferentes especies de capital en las

\footnotetext{
34 Sautu, R., Boniolo, P., Dalle, P. y Elbert, R., Manual de metodología. Construcción del marco teórico, formulación de los objetivos y elección de la metodología, Buenos Aires, CLACSO, 2005.

35 Bourdieu, P., La miseria del mundo, Fondo de Cultura Económica, 1999c, pág. 120.

36 Grimson, A., Los límites de la cultura. Crítica de las teorías de la identidad, Buenos Aires, Siglo Veintiuno Editores, 2011.

37 Los datos de esta base fueron trabajados con el programa estadístico informático Statistical Package for the Social Sciences (SPSS).
} 
estructuras patrimoniales de la mayor parte de las familias del territorio.

Las divisiones físicas-sociales dentro del territorio, analizando formas de conocimiento que sobre el espacio tienen los agentes sociales, se pudieron rastrear desde una diversidad de entrevistas realizadas en el marco de este proyecto y por procesos de investigación anteriores.

Asimismo, se retomaron algunos aspectos de la historia del barrio según ciertas lógicas prácticas, haciendo referencia al accionar de diversas organizaciones sociales y del Estado. En definitiva, se conceptualiza al espacio como un barrio de clases populares, según los datos cualitativos y cuantitativos obtenidos de las fuentes secundarias.

Ahora bien, lo que interesa reconstruir son las condiciones objetivas dentro de la escuela, dando cuenta, en términos generales, de los recursos movilizados y las posiciones ocupadas por los agentes que participan del espacio, por medio de observaciones, entrevistas y otras fuentes secundarias.

Con el objetivo de acceder a las estructuras objetivas incorporadas por parte de los agentes institucionales, se desarrollaron entrevistas semi estructuradas y abiertas, cuya muestra teórica fue intencional y selectiva, ya que se entrevistaron solo a directivos y docentes que participan del espacio de la jornada extendida. Los alcances de este abordaje se definieron por criterios de saturación teórica. Cabe remarcar que dichas entrevistas fueron previamente sometidas al análisis continuo, a partir de la construcción de guías -aunque flexibles- para la mayor precisión de un registro de tipo etnográfico. ${ }^{38}$

38 Las guías de entrevistas se estructuraron, fundamentalmente, bajo tres ejes, que buscaron rastrear las percepciones y apreciaciones de los agentes institucionales de la jornada extendida según: a) sus trayectorias docentes; b) sus interacciones con los/as alumnos/as en la escuela; y c) sus sentidos construidos respecto a las familias del barrio. De un total de once entrevistas, seis se realizaron bajo esta investigación y las restantes en el marco del proyecto "Prácticas de sectores populares en contextos de pobreza". Por otro lado, cabe decir que el cuerpo docente de la escuela es reducido; para el caso de jornada extendida hay una maestra para los campos de Inglés, Literatura, Tecnologías de la Información y las Comunicación (TICS) y Artística (maestra 1); otra para Educación Física (maestra 2) y otra para Ciencias (maestra 3). Teniendo en cuenta estas dimensiones, la muestra trabajada 
A su vez, la aproximación a los esquemas de percepción y acción de los agentes institucionales, se sistematizó mediante guías de observación y notas de campo detalladas, conformando el cuaderno de campo, con función de describir y re-crear los datos, desde las problemáticas de la investigación. ${ }^{39}$

La estructuración de las categorías, propiedades y dimensiones que se recuperaron conforman la cartografía de la escuela, como criterio teórico-metodológico de representatividad de la estructuración objetiva de las subjetividades de los agentes involucrados. Dicho mapa se organizó según núcleos temáticos que recogieron frases significativas del trabajo de campo, posibilitando analizar las representaciones y prácticas enclasantes. De este modo, se interpretan las prácticas de las educadoras según redes de significados, como construcción hipotética de relaciones entre relaciones probables.

Más allá de que el eje de investigación estuvo puesto en la trama de discursos y prácticas de las educadoras, la intervención en la escuela, participando de los espacios de jornada extendida -específicamente en el campo de Artística-, permitió examinar algunos sentidos subyacentes en las experiencias escolares de los niños y las niñas, cuestión que es fundamental al momento de pensar la relación entre las educadoras y los educandos. En el plano de la investigación-intervención se tensionaron dos temporalidades, combinando la urgencia de la interacción con la suspensión del tiempo cotidiano para habilitar la duda sobre lo que se produce y se piensa.

por la investigación resulta significativa, ya que se entrevistó al total de agentes institucionales de jornada extendida, a la directora y a la maestra de apoyo o integradora que también participan del espacio.

39 Las observaciones permitieron registrar prácticas según: cuáles son las "reglas de convivencia" en los espacios-tiempos y en las interacciones entre los docentes y los/as niños/as y entre los propios niños/as; qué mirada adulta está operando sobre las prácticas corporales de los/as niños/as; qué dispositivos áulicos e institucionales estructuran la cotidianidad escolar; qué lugar tiene el "reto" y/o el "cuidado" del adulto hacia el/la niño/a; cómo se apropian los/as niños/as de los espacios-tiempos de la escuela; cómo es la relación entre los adultos y los/as niños/as en las situaciones de enseñanza-aprendizaje; entre otras cuestiones. Este corpus empírico de carácter etnográfico conforma un total de 28 notas de campo en las que se detallan, mediante varias hojas, lo ocurrido en la cotidianidad de la escuela. 
Por último, se profundizó en bibliografía para precisar los distintos aspectos teóricos-metodológicos. También, se recurrió a diversas fuentes secundarias a fin de acceder al contexto global, mediante bibliografía especializada, documentos oficiales, estadísticas oficiales e investigaciones previas pertinentes.

Para finalizar, cabe retomar una frase sobre el camino epistemológico y metodológico que se buscó seguir, ya que, como manifiesta Jean-Claude Combessie, en El método en sociología:

El objetivo del sociólogo no es encontrar algún 'buen método'-objetivamente neutro- sino más bien, ajustar un dispositivo que [...] confronte eficazmente las luces de los métodos y refuerce su capacidad para objetivar los sociocentrismos: los de las representaciones y prácticas de los grupos que estudia y las que, incluso erudita, compromete, lo quiera o no, en su investigación..$^{40}$

De este modo, se reconocen otros de los elementos de la teoría del conocimiento estructural-constructivista que se relacionan con el principio de la no conciencia y la crítica a la ilusión de la transparencia. ${ }^{41}$

Combessie, J.c., El método en sociología, París, Ferreyra Editor, 2003, pág. 153.

41 Bourdieu, P., Chamboredon, J., y Paseeron, J.c., El oficio de sociólogo: presupuestos epistemológicos, Buenos Aires, Siglo Veintiuno Editores, 1975. 

CAPÍTULO III

El Barrio 

(...) hay como tres divisiones en el barrio: el Plan Eva Perón, que está en el corazón del barrio (...) están los antiguos que son de esa cuadra. Es como que para ellos no existe el barrio (...) y después están los terrenos usurpados que es otra gente, que allá se concentró bolivianos, paraguayos y hay alguna gente que ha venido de otros lados (...) por lo que el barrio es un collage $(. ..){ }^{1}$

Esta sección del trabajo busca dar cuenta de las condiciones objetivas de la mayor parte de las familias del barrio en el que se inserta la escuela, lo cual permite constituir a este territorio como un barrio de clases populares.

Re-construir las diferentes especies de capitales que definen posiciones en el espacio físico-social implica analizar las visiones y divisiones sociales que se producen respecto a esa configuración social, lo cual es habilitado por las propias condiciones estructurales y auto percepciones de los habitantes y, asimismo, el espacio en cuestión está atravesado por la mirada de "los de afuera". Para el caso, interesa retomar, específica aunque no exclusivamente, las representaciones sobre el barrio que elaboran los agentes institucionales de la escuela, según sus posiciones, lo cual, sin embargo, se profundizará una vez reconstruidas las trayectorias docentes de estos agentes.

El espacio social reificado: un barrio de clases populares

A continuación se presentan algunas definiciones teóricas que posibilitan explicar las relaciones entre espacio físico, espacio social y construcciones de sentido en torno a ello.

Según Bourdieu, en La miseria del mundo², los agentes, en tanto cuerpos, al igual que las cosas, están situados en un lugar y ocupan un sitio. El lugar es definido por Bourdieu como el

Fragmento de entrevista realizada a la directora de la escuela (1), bajo el proyecto "Prácticas de sectores populares en contextos de pobreza", 2012.

2 Bourdieu, P., La miseria del mundo, Fondo de Cultura Económica, 1999c. 
espacio físico en el que se encuentran los mismos, ya sea como localización, ya sea como posición. Tanto los agentes sociales, como las cosas en cuanto los agentes se apropian de ellas, están situados en el espacio social, posición relativa que se define en relación a las otras posiciones. Así, el espacio apropiado funciona como una especie de simbolización del espacio social que se retraduce de esta forma en el espacio físico. La apropiación y la distancia física con respecto a los bienes dependen entonces de la estructura y del volumen de capitales poseídos durante la trayectoria social del agente.

Ahora bien, el espacio físico, en cuanto espacio social objetivado, produce y reproduce categorías de pensamiento y apreciación, de visión y división -habitus-que son interiorizadas por los agentes como formas de evaluar su posición y la de los demás en el espacio social general; en definitiva, el espacio físico-social es principio organizador de las prácticas sociales.

Tales criterios clasificadores, al ser generados en y por relaciones sociales de dependencia, tienden a reproducir subjetivamente las relaciones objetivas de dominación:

En una sociedad jerárquica, no hay espacio que no esté jerarquizado y no exprese las jerarquías y las distancias sociales, de un modo (más o menos) deformado y sobre todo enmascarado por el efecto de naturalización que entraña la inscripción duradera de las realidades sociales en el mundo natural ${ }^{3}$.

El espacio social entonces se encuentra inscrito en las estructuras espaciales y en las mentales, por ello el espacio físico se constituye en uno de los lugares donde se afirma y se ejerce el poder, como violencia simbólica.

El espacio físico-social de la investigación, además de analizarse en función de las diferentes posiciones que lo componen, es interpretado como un barrio popular, definido por Merklen como el "espacio de la inscripción territorial [de los agentes so-

Ídem., Op.cit., pág.120. 
ciales] entendida como una forma de inscripción social a través de la ciudad". ${ }^{4}$

De esta manera, se recupera la dimensión externa del territorio barrial, dado que el espacio en cuestión se configura a partir de la relación que establece con los barrios lindantes y con el resto de la ciudad, así como con lógicas provenientes del espacio municipal, provincial y nacional, instituciones del tercer sector o privadas, y las propias organizaciones barriales.

Lo anterior implica pensar al territorio barrial como un espacio en el que se movilizan e intercambian variedad de recursos, normas y estilos de vida, así como formas de identidad social y de cohesión territorial ya que pertenecer o no a un determinado territorio puede ser fuente de orgullo o vergüenza: puede ser una marca de distinción social.

\section{La historia del barrio y sus condiciones objetivas}

El barrio se encuentra ubicado en el sector noroeste de la ciudad de Villa María, entre los límites definidos por el cementerio municipal -en el sector este- y por las redes viales -al norte y al sur- correspondientes con las redes del ferrocarril que "se bifurcan desde el casco céntrico, procurando sus respectivos destinos, unas hacia Río Cuarto y otras hacia Córdoba" 5 . El territorio se constituyó en uno de los barrios más postergados de la ciudad, fundamentalmente, en lo que respecta a la prestación de servicios públicos. En este marco, se produjeron, históricamente, procesos de organización vecinal que tuvieron como objetivo la incorporación de servicios públicos básicos y la construcción de obras vinculadas con la escuela primaria,

Merklen, D., "Con los pies en la tierra: la inscripción territorial de las clases populares -en Argentina y en otros lugares-", en Pobres ciudadanos. Las clases populares en la era democrática (Argentina, 1983-2003), Buenos Aires, Gorla, 2005, pág. 164.

5 Calvo, B., Historia popular de Villa María, Tomo II, Córdoba, 1989, pág. 212. 
el centro vecinal, el dispensario, la guardería, el jardín, entre otras instituciones. ${ }^{6}$

En términos poblacionales, es necesario distinguir diferentes momentos que aluden, por un lado, a la implementación de dos etapas de un plan social de viviendas municipal y, por otro, en el año 2009, se produjo un proceso de ocupación de tierras que luego fueron urbanizadas por el mismo municipio. En este sentido, cabe aclarar que el barrio fue paulatinamente provisto de servicios públicos, cuenta con pavimento, agua, cloacas, gas natural, energía eléctrica y alumbrado público; sin embargo existe una distribución desigual de estos recursos y, por lo tanto, una apropiación diferencial de los mismos por parte de los vecinos.

A partir de resultados de la investigación "Prácticas de sectores populares en contextos de pobreza", se pudo caracterizar al barrio como una de los espacios más postergados de la ciudad, conformado principalmente por pobres estructurales y, en menor medida, por grupos sociales medios bajos; esta configuración social se ubica entonces en una posición subordinada en el espacio social general, en función de la acumulación de capital económico y cultural de sus habitantes.

\section{Capital económico}

Si se tiene en cuenta en la composición del capital económico a los ingresos monetarios y a los ingresos no monetarios, se observa que las estrategias para obtener ingresos de tipo monetario se agrupan, en mayor media, entre ingreso por trabajo (casi el 80\%) e ingreso por Asignación Universal por Hijo (aproximadamente la mitad de las familias). Las cifras de las de-

\footnotetext{
6 En el barrio se relevaron instituciones pertenecientes tanto al ámbito estatal y al partidario, como al espacio no estatal y asociativo. Al momento de indagar algún grado de relación o participación alrededor de estas instituciones, las más mencionadas fueron: el dispensario municipal $(25 \%)$, el municerca $(23 \%)$, la capilla $(12 \%)$ y el centro vecinal $(9 \%)$. Por lo tanto, el soporte de la red institucional termina siendo muy valorado con $86 \%$ de personas que hace algún uso de la red institucional.
} 
más variables (planes sociales, becas, jubilación y pensión) son comparativamente menos relevantes, según los datos arrojados por el siguiente cuadro:

Tipo de ingreso monetario por unidad doméstica

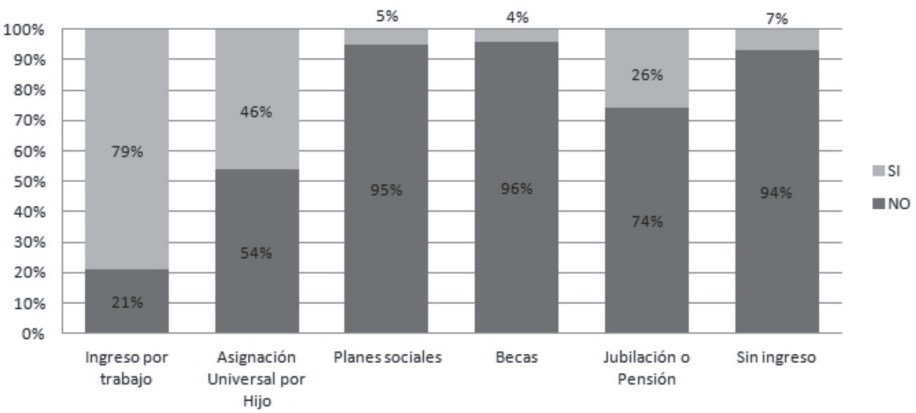

Se visualiza que solo el $14 \%$ de las unidades domésticas (UD) percibe únicamente ingresos monetarios sin estar inserto o relacionado al ámbito laboral, formal e informal, es decir, sólo ingresos extra-salariales. En contraposición, casi la mitad (49\%) genera sus ingresos monetarios a través de dos vías simultáneas: ingreso por trabajo e ingreso por Asignación Universal por Hijo:

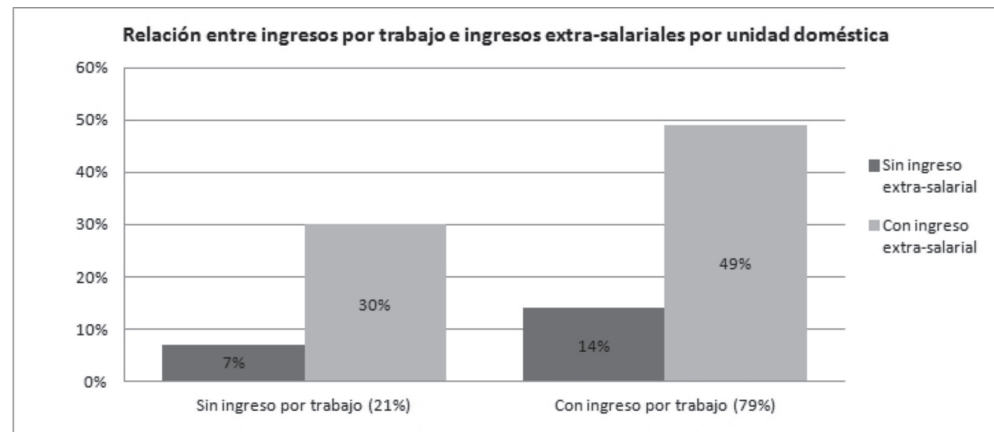

Fuente: Censo realizado por el equipo de investigación "Prácticas de sectores populares en contextos de pobreza", junio 2012.

Por lo tanto, el aporte que realizan los ingresos extra-salariales, proporcionalmente en las estrategias de vida de las fami- 
lias, es significativamente menor al que le suele adjudicar el sentido común hegemónico que supone que quien percibe planes sociales y/o asignaciones "no trabaja". Por su parte, los datos relacionados a los ingresos no monetarios confirman la misma tendencia, ya que el $65 \%$ de las unidades domésticas prescinden de este tipo de recursos, tal como se expone en el siguiente cuadro:

Ingreso no monetario en términos de ayuda alimentaria por unidad doméstica

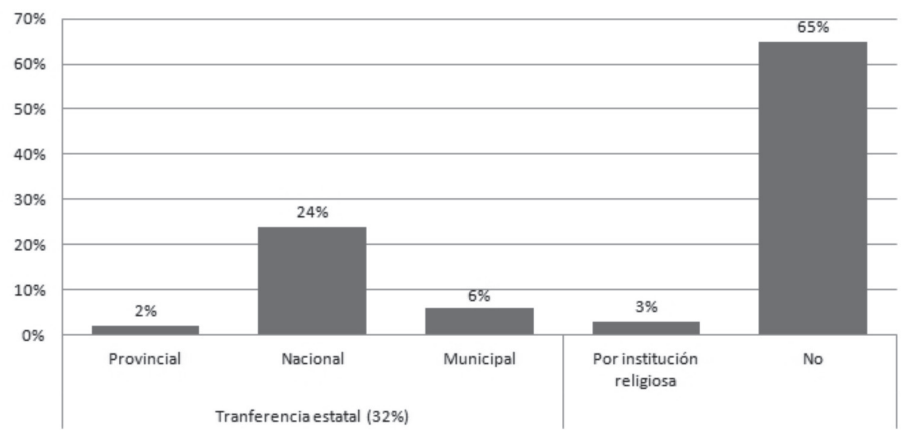

Fuente: Censo realizado por el equipo de investigación "Prácticas de sectores populares en contextos de pobreza", junio 2012.

Otro dato importante a tener en cuenta en relación al rendimiento del capital económico es la situación de acceso a la vivienda: el $46,4 \%$ de los encuestados afirmó que el lote es propio, ya sea con escritura o con boleto compraventa; un $27 \%$ tiene casa propia con escritura, un $27,8 \%$ propia pero sin escritura y un $11 \%$ propia con boleto compraventa: ${ }^{7}$

7 Estos datos revelan que, sin embargo, hay una "legalidad precaria" en la tenencia de los lotes y las casas, porque hay más porcentaje de casas propias que de lotes propios. 


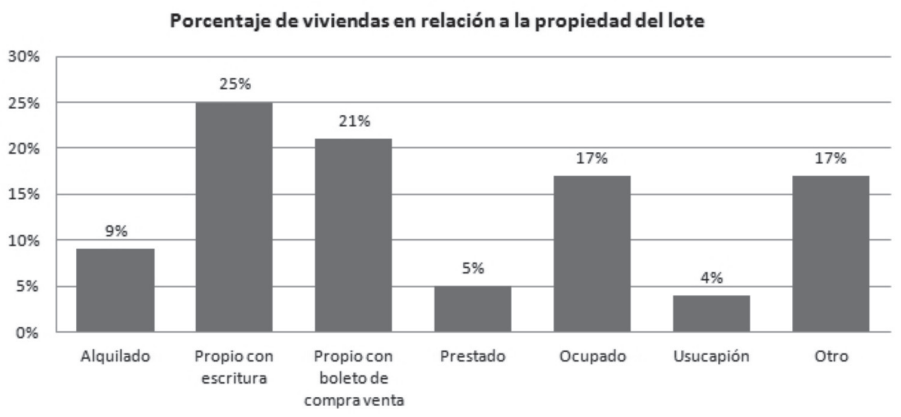

Fuente: Censo realizado por el equipo de investigación "Prácticas de sectores populares en contextos de pobreza", junio 2012.

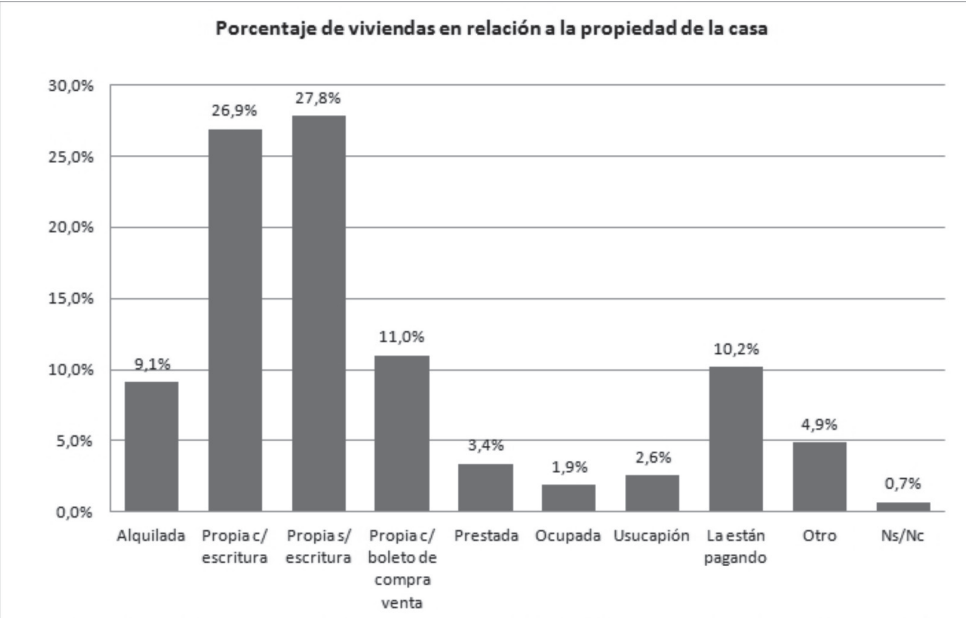

Fuente: Censo realizado por el equipo de investigación "Prácticas de sectores populares en contextos de pobreza", junio 2012.

En relación a la vivienda, se destaca que en las condiciones de las familias solo un $10 \%$ refiere a casos de hacinamiento crítico -más de tres personas por habitación-y alrededor del 5\% presenta hacinamiento moderado -tres personas por habitación-: ${ }^{8}$

8 El criterio de definición fue tomado del Instituto Nacional de Estadística y Censos de la República Argentina (INDEC), considerando hacinamiento moderado para los casos en los que hay tres personas por habitación; hacinamiento crítico para los casos en donde hay más de tres personas por habitación; y no hay hacinamiento en los casos en los que habitan menos de tres personas por habitación. El indicador no contabiliza como habitación al baño. 


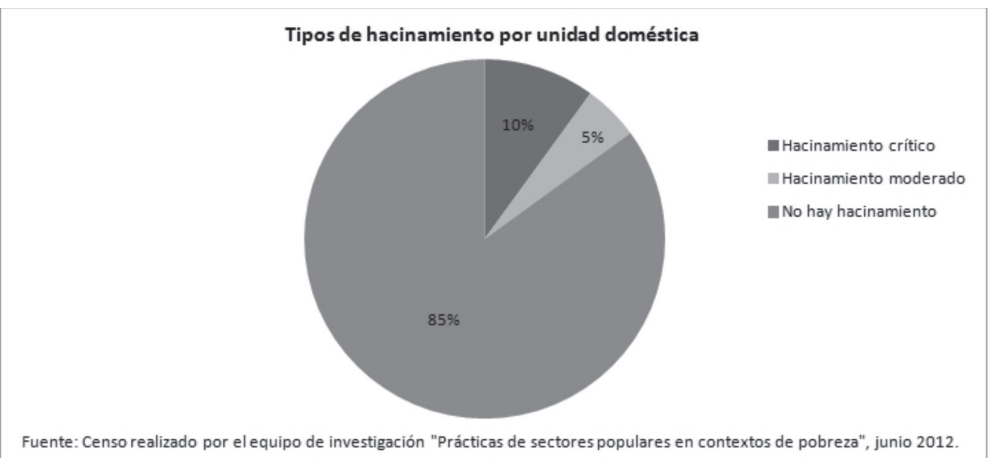

Capital cultural

Si bien existen varias formas para clasificar a este tipo de capital, se presentan solo los datos obtenidos en relación al capital adquirido en el sistema de educación formal. Así en los niveles de escolarización alcanzados por los adultos, el $45,8 \%$ tuvo acceso a nivel primario, el $42,3 \%$, al secundario y un $11,9 \%$, al nivel superior:

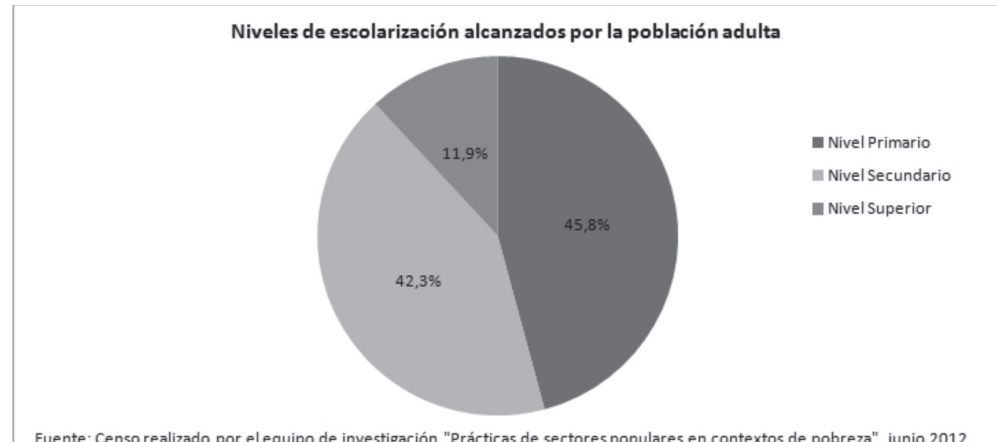

En el grupo etario de 19 a 35 años, el nivel de instrucción preponderante es secundario incompleto y primario completo. En las edades que van de 36 a 50 años, los porcentajes son pare- 
cidos al grupo etario anterior, entre primario completo y secundario incompleto, aunque el porcentaje más significativo se encuentra en el primario completo. En cuanto a las personas entre 51 a 65 años predomina el primario completo. A partir de los 66 años se observa que la gran mayoría alcanzó el primario pero no lo completó:

\begin{tabular}{|l|c|c|c|c|}
\hline \multirow{2}{*}{ Nivel de estudios } & \multicolumn{4}{|c|}{ Grupos por edades } \\
\cline { 2 - 5 } & $\mathbf{1 9 - 3 5}$ & $\mathbf{3 6 - 5 0}$ & $\mathbf{5 1 - 6 5}$ & $\mathbf{6 6}$ y más \\
\hline Sin estudios formales & - & $2 \%$ & - & $3 \%$ \\
\hline Primario incompleto & $10 \%$ & $16 \%$ & $22 \%$ & $\mathbf{5 9 \%}$ \\
\hline Primario completo & $\mathbf{2 0 \%}$ & $\mathbf{3 5 \%}$ & $\mathbf{5 0 \%}$ & $30 \%$ \\
\hline Secundario incompleto & $\mathbf{4 3 \%}$ & $\mathbf{2 9 \%}$ & $19 \%$ & $8 \%$ \\
\hline Secundario completo & $17 \%$ & $10 \%$ & $\mathbf{9} \%$ & - \\
\hline Terciario incompleto & $3 \%$ & $2 \%$ & - & - \\
\hline Terciario completo & $3 \%$ & $2 \%$ & - & - \\
\hline Universitario incompleto & $3 \%$ & $3 \%$ & - & - \\
\hline Universitario completo & $1 \%$ & $1 \%$ & - & - \\
\hline
\end{tabular}

Fuente: Censo realizado por el equipo de investigación "Prácticas de sectores populares en contextos de pobreza", junio 2012.

Con respecto a la población en edad de asistir a la escuela secundaria, específicamente entre 12 y 18 años, el 70,6\% está asistiendo a la escuela secundaria -año 2012-, en contraposición al 29,5\% que no está siendo escolarizando para dicho nivel educativo:

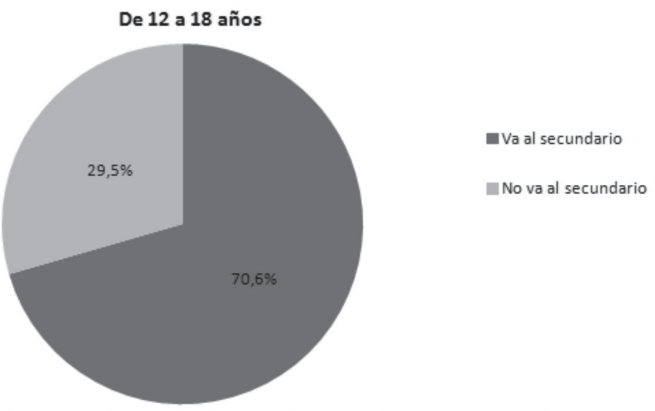


Respecto a la población de niños y niñas del barrio que se encuentran en edad de asistir a la escuela primaria, el 97, 9\% asiste a la escuela y solo un $2,2 \%$ no asiste:

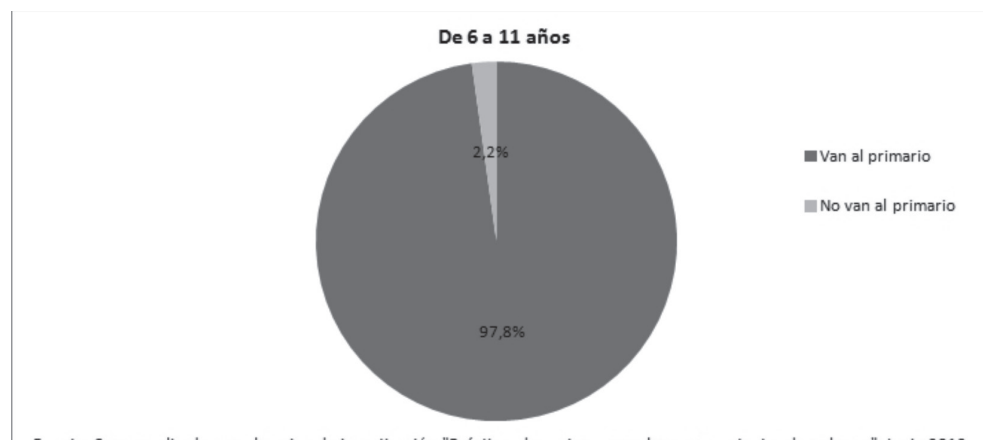

Fuente: Censo realizado por el equipo de investigación "Prácticas de sectores populares en contextos de pobreza", junio 2012.

Algunos de estos datos serán retomados en los capítulos VI y VII, donde se analizan los actos enclasantes y de enclasamiento que elaboran los agentes institucionales con respecto a los niños, las niñas y sus familias del barrio.

Visiones y divisiones sociales sobre el territorio

Otro dato importante son las distintas visiones y las prácticas sociales en relación a este territorio, que se construyen tanto por "los de adentro" como por "los de afuera del barrio", lo cual implica la incorporación de esquemas clasificatorios, en el marco de condiciones objetivas similares como desiguales. La simbolización del orden social en las clases dominadas está atravesada por miradas construidas sobre ellas por las clases dominantes, pero también por las interpretaciones construidas desde los repertorios que sus propias condiciones objetivas producen.

Bajo estas miradas en disputa, las visiones sobre los diferentes grupos sociales que conviven en diversos espacios del territorio se configuran a partir de la construcción de un "otro", ya sea 
extranjero, vecino nuevo, vecino antiguo, joven peligroso, "los que viven de planes", entre otras definiciones.

En el caso de las educadoras de jornada extendida, es importante remarcar que todas viven en barrios del centro o en barrios que son habitados por sectores sociales medios de Villa María, definidos por las mismas maestras como "barrios de clase trabajadora”. Esto lleva a que muchas docentes conozcan el barrio en cuestión a través de los prejuicios elaborados por sus compañeras más antiguas, quienes a pesar de que tienen conocimiento de algunas situaciones históricas de pobreza -relativa- del lugar, enfatizan justamente los relatos de las "carencias" de los "otros", centrándose en los aspectos negativos de sus vidas, que deben tenerse en cuenta, pero que en ocasiones limitan las lecturas. Así, estas educadoras no "salen" frecuentemente de la escuela para reconocer que el territorio está atravesado por otras dinámicas, recursos, agentes, que lo posicionan de modo diverso en el espacio social general. En definitiva, estos agentes institucionales construyen la otredad a partir de "ser de afuera".

Un ejemplo de este cruce de miradas remite a las percepciones cruzadas ("del afuera y del adentro") en relación a los supuestos "recién llegados" por la toma de terrenos y en referencia a "los que viven de planes":

(...) el barrio ha cambiado para mal digamos (...) ha cambiado mucho el barrio desde que se tomaron la parte de las tierras de allá [hace una seña] y también con el plan de las casitas Eva Perón (...) yo conozco sobre todo la parte vieja del barrio, antes era más tranquilo, ahora hay mucho robo, mucha droga (...). ${ }^{9}$

(...) yo creo que los chicos son iguales, son traviesos como hace 17 años, lo que ha cambiado es el barrio en sí, ha venido mucha gente de afuera, de otros lados, sobre todo ahí viste en el Plan Eva Perón, nosotros nos nutrimos en la escuela de ese barrio, de ese sector del barrio, que la mira-

Fragmento de entrevista realizada a maestra de jornada extendida (1), 2014. 
da que uno tiene es que ellos no tienen o no pueden estar incluidos en otras escuelas públicas pero del centro (...). ${ }^{10}$ Hasta el Plan Eva Perón, era el barrio (...) llegó mucha gente (...) familias completas con capacidades diferentes (...) chicos preadolescentes muy atorrantes, mucha droga y alcohol (...) antes todos nos conocíamos (...) insertaron el Barrio Eva Perón dentro de este barrio (...) habrá gente trabajadora, pero hay muchos chicos haciendo cosas que no tienen que hacer (...). ${ }^{11}$

Aparece esto de que la culpa era de los otros, o sea de los Eva Perón, que en realidad yo digo la primer Eva Perón eran ellos mismos, la mitad eran ellos o familias que ya vivían en el barrio (...)..$^{12}$

Algunas de estas clasificaciones que operan en los procesos por los cuales las clases y fracciones de clase "se enclasan y enclasan a los demás", se retomarán para analizar desde qué posiciones y discursos hegemónicos las educadoras de la escuela del barrio se referencian a las estrategias de reproducción de las familias del territorio, cuyas visiones y divisiones, en este caso, están mediadas por las prácticas pedagógicas de los agentes institucionales en el espacio de la escuela.

\footnotetext{
10 Fragmento de entrevista realizada a la directora de la escuela (2), 2014.

11 Fragmento de entrevista realizada a una de las fundadoras del dispensario y un comedor en el barrio, bajo el proyecto "Prácticas de sectores populares en contextos de pobreza", 2012.

12 Fragmento de entrevista realizada a ex trabajadora social del dispensario del barrio, bajo el proyecto "Prácticas de sectores populares en contextos de pobreza", 2012.
} 
CAPÍTULO IV El campo escolar 

(...) mañana no comes acá, te vas a tu casa, sí señor (...) encima que te damos de comer; acá no tenemos la obligación de darte de comer (...).

La configuración de la escuela: entre historias de segregación y relatos de contención social

La escuela se encuentra ubicada en uno de los límites del barrio. El proceso que originó su constitución se recuperó, en gran parte, desde un documento institucional denominado La historia de mi vida, donde se redacta, en primera persona -como si fuera la propia escuela la que narra-, sobre los agentes que se involucraron con la construcción y las modificaciones del edificio, hasta 1996.

Resulta significativo incluir en este caso algunos de estos datos ya que permiten visualizar la historia de segregación que conecta a la escuela con la historia del vecindario, no solo a nivel material sino también simbólicamente.

Es interesante mencionar cómo desde un principio los agentes municipales y discursos especialistas percibían al barrio:

En realidad, yo [la escuela] tendría que haber sido construida en el barrio Belgrano, ya que los estudios estadísticos realizados demostraban que contaban con una mejor ubicación y tenían buenas perspectivas de progreso, pero por cuestiones que desconozco, me construyeron en otro lugar. ${ }^{2}$

El documento posibilita dar cuenta de los agentes que movilizaron recursos para la conformación de la escuela, los cuales siguen operando en gran parte, entre ellos, la municipalidad, el Rotary Club, la capilla y el dispensario.

Asimismo, analizar algunas declaraciones presentes en el documento permite reconstruir en clave histórica algunos discursos

Nota de campo 2, 8-05-2014.

2 Documento La historia de mi vida, página 9, 1996. 
que siguen formando parte la matriz sacra de la escuela y del proyecto institucional -al menos discursivamente- ya que, por ejemplo, según la directora de la escuela este documento es utilizado para realizar las glosas de los actos, como medio para reivindicar ciertos discursos escolares.

En el documento se parte de definir a la escuela como "un lugar confortable y ameno para la educación de los niños" origina cuando "surge la necesidad de crear un lugar donde todos ellos [los/as niños/as] pudieran formase cultural, espiritual y pedagógicamente"4. En sus orígenes funcionaba en una casa que se encontraba dentro del cementerio ubicado en el barrio y solo contaba con sesenta alumnos/as.

Desde un comienzo estuvieron presentes las gestiones para que en la escuela se sirviera la merienda a los niños y las niñas:

[...] el Club de Leones nos donaba los bizcochos todos los meses y cuando comenzó a funcionar en Villa María la fábrica La Lactodea en el barrio Belgrano, nos regalaba la leche, pudiendo ofrecer así desde mis inicios la copa de leche a todos mis hijos. ${ }^{5}$

Se observa cómo el proceso de formación de la escuela se relaciona con actividades de caridad hacia el pobre, articulado por distintos agentes: "El afán de superación, las ganas de ayudar al necesitado hacen que la directora [de 1948] realice todo tipo de trámites ante el gobierno provincial y la municipalidad local"'. En 1954 se traslada al actual terreno -donado a la provincia por una familia reconocida de Villa María- con dos aulas, la dirección y un baño para niñas y otro para varones.

En 1961 se crea la cooperadora escolar haciendo socios de la misma a muchos comerciantes de la ciudad, con la finalidad de abrir el comedor escolar, el cual en sus inicios funcionó en la casa de una vecina del barrio.

\footnotetext{
Ibídem, página 5.

4 Ibídem, página 8.

5 Ibídem, página 8-9.

6 Ibídem, página 9.
} 
Cerca de 1972 se construyen otras aulas con el apoyo del Rotary Club. Para 1974, la escuela tenía todos los grados, el comedor y la copa de leche y contaba con ciento treinta alumnos/as. El Rotary Club también construye el baño para maestras en 1978.

Después de 1982, se cae el techo de la dirección que es reconstruido por el Rotary Club; singularmente, este grupo de agentes es definido en el texto como "los amigos de siempre". ${ }^{7}$ Nuevamente, en 1983, el Rotary inaugura el patio de ceremonias.

En 1984 con el Programa de Asistencia Integral de Córdoba (PAICOR): “Mis niños [los/as alumnos/as de la escuela] almuerzan en el comedor de la capilla, que muy gentilmente nos presta sus instalaciones, para que el plan PAICOR pueda allí desarrollarse, beneficiando a muchos de nuestros alumnos". ${ }^{8}$

La construcción en un edificio aparte del jardín de infantes fue coordinada también por el Rotary Club a partir de 1985.

En 1989 se tramita con la municipalidad la construcción de: el comedor propio y bien equipado, cocina, dos aulas, galería, tapia, vereda y rejas.

Para 1990, el documento señala "La crisis económica también me llegó [a la escuela] ¡no hay más fondos! debo pedir socorro a la municipalidad, le paso todos los expedientes para que continúen la obra". ${ }^{9}$ El jardín de infantes es terminado en 1992, en el marco del aniversario de la ciudad.

Bajo la transformación educativa de los 90, se destaca: “la reducción horaria del personal del PAICOR hace que los docentes tengan más trabajo y deban cumplimentar la faz pedagógica y cubrir las necesidades prioritarias de higiene de mi edificio". ${ }^{10}$

Por otra parte, para 1996, comienzan a intervenir diversos agentes destinados a "solucionar" los "problemas de aprendi-

\footnotetext{
Ibídem, página 15.

Ibídem, página 15.

Ibídem, página 18.

10 Ibídem, página 21.
} 
zaje, expresividad y conducta" de algunos niños y niñas; desde entonces la escuela cuenta con el trabajo de psicopedagogas, fonoaudiólogas, maestras de apoyo escolar, trabajadoras sociales, entre otros actores e instituciones.

Otros grupos que según el documento "aportan su granito de arena"11 con juguetes, útiles, ropa, frazadas, calzado, especialmente para el día del niño y del estudiante, son el Rotary en Acción (ROTARACT) y la Liga de Madres de la Santísima Trinidad -cuyos miembros se articulan con el Instituto Trinitarios o Santísima Trinidad-, esta última organización definida por los/ as niños/as como las "tías".

En definitiva, la historia de la escuela da cuenta de las dificultades para solventar la falta de recursos básicos para su funcionamiento -fundamentalmente respecto al edificio- y la necesidad de brindar, bajo un concepción asistencialista, la merienda y/o almuerzo en la escuela como respuesta inmediata, en parte, a las condiciones objetivas desventajosas del barrio -actividad que se mantiene-.

Hasta finalizada la década del 90, se concibe la falta de intervención sistemática en educación por parte del Estado y un predominio del accionar de organizaciones no gubernamentales, como el Rotary Club, Club de Leones, Rotary en Acción y la Liga de Madres de la Santísima Trinidad, cuyos fondos provienen de donaciones de empresarios y profesionales de varios campos; a pesar de los matices entre estas organizaciones, se puede decir que todas "prestan servicio en sus comunidades"12 y obtienen de este tipo de prácticas signos de distinción social.

Para el momento de la investigación, estas organizaciones siguen teniendo un accionar prioritario dentro del espacio escolar. Hace algunos años el Rotary Club instaló la conexión de gas en la escuela, lo cual es manifestado por la directora del siguiente modo:

11 Ibídem, página 21.

12 Fragmento extraído de la página oficial de Rotary Club Villa María. 
Lo que vamos hacer en el acto [del día del maestro, para el año 2014] es descubrir la placa en homenaje al día del maestro, placa que le hicimos al Rotary (...) es la placa de la obra de gas, ya que nos pusieron el gas hace dos años, toda la instalación todo, y bueno, por una cosa u otra vamos a entregar ahora la placa que ellos te piden (...). ${ }^{13}$

Este tipo de accionar re-produce representaciones en los agentes institucionales de la escuela que impiden la interpelación que la institución debería generar respecto al Estado, para la obtención de recursos para los niños y las niñas de clases populares en clave de derechos.

Para finalizar, en el documento se escribe acerca de cuál es el propósito de la escuela, discurso que de algún modo sigue operando en las tomas de posición de los agentes institucionales, en tanto reproducción de la cultura institucional:

Más allá de la simple tarea de educar, con la firme convicción de Dar, de ser Solidaria, de Cobijar con amor a quienes lo carezcan y tender una mano amiga a quien lo necesite. $\mathrm{Mi}$ gran meta, fundamentalmente, es poder resguardar a mis niños de la agresión, la violencia y la indigencia, tratado de formar Personas de Bien, para un mañana mejor [...] MUCHAS GRACIAS Y QUE DIOS LOS BENDIGA. ${ }^{14}$

Redes de agencias y campos

Como se pudo detectar mediante el rastreo de la historia de la escuela, la misma está intervenida por el accionar de diversos agentes y relaciones entre agentes que distribuyen y se apropian de diferentes recursos que circulan en el campo escolar, generándose incluso interacciones con otros campos -el religioso y el asociativo, por ejemplo-. A continuación de describen y analizan otras redes presentes en el espacio escolar.

13 Nota de campo 24. 08-09-2014.

14 Documento La historia de mi vida, página 21, 1996. 
A nivel nacional, los recursos son: A) programa Leer con Todo, centrado en la intensificación de la enseñanza de la lectura en todas las escuelas primarias del país. A partir del 2014, se hace extensivo a todos los grados de la escuela primaria. Bajo este programa, la escuela del barrio cuenta con bibliotecas individuales en cada aula y una biblioteca central en la sala de informática. Empero, el uso de los libros por parte de los/as niños/ as está restringido por los adultos, lo cual conlleva a que los materiales se utilicen en pocas ocasiones y bajo determinadas actividades.

B) Programa de Apoyo a la Política de Mejoramiento de la Equidad Educativa (PROMEDU) cuyo objetivo "es mejorar la equidad de la educación inicial, primaria y secundaria y contribuir a cerrar la brecha existente en las oportunidades educativas de los niños y jóvenes pertenecientes a distintos estratos de ingreso"15; para el caso de la escuela, mediante este programa se financian capacitaciones, específicamente, en matemáticas para segundo ciclo del nivel primario.

C) Programa Integral para la Igualdad Educativa (PIIE), formulado a partir del año 2004 para dar respuesta a las problemáticas relacionadas con la fragmentación social y la desigualdad de oportunidades educativas.

Según las informaciones obtenidas del documento base del PIIE, sus objetivos son:

1. Apoyar las iniciativas pedagógicas escolares: se propone que las escuelas diagramen e implementen una iniciativa pedagógica, es decir, un conjunto de acciones dirigidas al fortalecimiento de los procesos de enseñanza y aprendizaje. Para su implementación el PIIE ofrece a las escuelas

15 Datos obtenidos de la página oficial del Ministerio de Educación, Presidencia de la Nación. 
acompañamiento pedagógico y otorga un subsidio para cada institución.

2. Apoyar el ejercicio de la profesión docente: se prevé para los docentes de las escuelas actividades, encuentros y seminarios de formación y capacitación.

3. Fortalecer el vínculo de la escuela con la comunidad: se impulsarán acciones con diferentes organizaciones de la comunidad para ampliar el entorno educativo y conformar comunidades de aprendizaje.

4. Recursos materiales para las escuelas: cada escuela recibirá: una biblioteca de quinientos libros. Equipamiento informático. Vestimenta escolar. Un subsidio para útiles escolares.

5. Refuncionalizar la infraestructura escolar: se brindarán recursos económicos para el mejoramiento de la infraestructura escolar básica, especialmente destinados a la construcción, adecuación y mejoramiento de las salas de informática. ${ }^{16}$

Ahora bien, lo que se visualiza es una tensión entre los objetivos del programa y los proyectos educativos de la escuela en relación a los/as alumnos/as, impidiendo que la política tenga efectos reales en reforzar los procesos de calidad e inclusión educativa. La oferta respecto a los/as niños/as queda sujeta, en gran medida, a las disposiciones, apreciaciones y percepciones particulares de las educadoras que siguen ancladas, en su mayoría, en el sistema de sentido de la carencia. ${ }^{17}$ En palabras de Patricia Redondo:

Las formas que asume cada gestión de gobierno y puesta en marcha de políticas socio-educativas saturan su discurso sobre la construcción de una ciudadanía más plena, pero la misma se limita cuando ello llega vía plan, diluyéndose la representación de los/as niños/as, adolescentes y jóvenes sobre aquello que les corresponde, les pertenece por derecho y que obliga a la sociedad civil y al Estado a garantizar.

\footnotetext{
16 Documento Base PIIE, Ministerio de Educación, Presidencia de la Nación.

17 Durante las actividades de jornada extendida en el campo de artística, se observó que los/as niños/as no tenían, en su mayoría, lápices, hojas, plasticolas, entre otros, ya que los agentes institucionales se consideran y se posicionan como "los gestores de la pobreza" -en términos similares a las otras organizaciones de beneficencia de diversos campos- quienes distribuyen, en este caso, los útiles escolares cuando lo consideran necesario y justo, según sus visiones enclasantes sobre el accionar de los/as niños/as.
} 
En una misma escuela pueden superponerse planes y proyectos que ubican a los/as directores como gestores de los mismos, casi como gestores de la pobreza y al resto como beneficiarios. Los derechos sociales y, entre ellos, los educativos, se licuan en momentos en que debieran asumir su carácter más universal, indelegable, irreductible. ${ }^{18}$

\section{A nivel provincial y/o local, las redes se establecen con:}

A) Instituto Secundario Bernardino Rivadavia, el cual todos los años realiza una actividad para el día del niño, mediante una jornada de juegos, comida y entrega de juguetes:

Las puertas de la escuela, como nunca, estaban abiertas de par en par, me llamó la atención porque normalmente están cerradas con llave. La jornada escolar se había suspendido en la totalidad de los cursos; incluso varias maestras habían faltado. Notamos que en el comedor de la escuela se servirían una variedad de tortas (todas ellas compradas) y se entregarían juguetes nuevos a los/as niños/as; era como si se hubiese construido una escenografía para recibir a los visitantes. ${ }^{19}$

El uso de esta red tiene entonces un peso material y simbólico, de distinción, en función de lo que representa el Instituto Rivadavia en Villa María.

B) Municipalidad de Villa María: la escuela se vincula con los centros educativos-culturales Tecnoteca y Medioteca ${ }^{20}$ y tam-

18 Redondo, P., Infancia(s) Latinoamericana(s), una deuda interna, un debate pendiente, Op. cit., pág. 13-14.

19 Nota de campo 18, 19-08-2014.

20 Los/as niños/as de la escuela asisten a estos espacios en varias oportunidades, los cuales son ocupados y coordinados, generalmente, por otros sectores sociales mejor posicionados en términos de capital cultural y económico en el espacio social general.

Mediante un registro de campo se detalla la falta de tiempo y materiales que se ponen en juego en estos espacios, para que estos niños/as puedan interiorizar los nuevos conocimientos y no simplemente "pasar para mirar". Asimismo se detectó, en una visita que se compartió con los/as alumnos/as, el lenguaje adulto y "culto" utilizado por los coordinadores y la falta de diálogo hacia los/as chicos/as para hacer comunicables e interesantes los saberes.

Aunque no es la intención desarrollar esta hipótesis en la investigación, es necesario remarcar que, en algunas ocasiones, los niños y las niñas de clases populares acceden a estos espacios públicos, aunque sus cuerpos circulan en ellos desde una lógica asociada generalmente a la gratuidad. Esta lógica se transforma en una apropiación subalternizada donde los bienes sociales, supuestamente a disposición de todos/as, siguen sosteniendo un acceso de estructuración clasista. Las instituciones escolares y los espacios culturales terminan 
bién con el programa La Natación Va a la Escuela, bajo el cual el municipio se hace cargo del traslado de los/as niños/as y el alquiler de la pileta.

Ahora bien, en la puesta en práctica de este programa, para el caso de la escuela del barrio, son pocos los niños y las niñas que concurren, cuyas causas, desde las percepciones de los docentes, se deben a:

(...) los chicos para este proyecto necesitan primero la aprobación médica, que la hacen en el dispensario, que no tienen que tener ni hongos ni piojos, después se firma bueno la autorización de los padres (...) del grupo tarde fueron re poquitos (...) lo que pasa es que en estas escuelas muchos no asisten, no tenían aprobado la ficha médica (...) lo que pasa es que a los chicos se les viene avisando (...) pasa que a mí me parece particularmente que es agresivo tener que decir chicos revísense la cabeza que tienen piojos y si tienen hongos en los pies, o sea, no me parece algo lindo de decir (...) lo que yo creo es que si hubiera contacto con los padres sería distinto que vos se lo digas a un papá que se lo digas al niño (...) y a la reunión fueron dos mamás entonces como te decía a la pileta faltan porque no tiene el apto físico, porque les da vergüenza a las nenas ir con maya y mostrarse delante de los compañeros, muchos no tienen maya directamente, entonces tampoco van (...). ${ }^{21}$

Por su parte, los agentes de la escuela distinguen otras redes según tres "cadenas" que enlazan una variedad de agentes, recursos, saberes y sentidos sobre cómo intervenir respecto a "las infancias vulnerables" y sus "familias problemáticas".

Cadena 1): para intervenir en los "casos de niños con problemas de aprendizaje, expresividad y conducta”, el vínculo se establece junto con el dispensario del barrio -que además de los agentes especializados en salud cuenta con una trabajadora social-, el municerca y, en casos más críticos, con la Secretaría de Niñez, Adolescencia y Familia (SENAF) de la provincia.

por reproducir las posiciones desiguales, cristalizadas en lugares y en objetos culturales que sostienen la separación de los cuerpos y de los lenguajes sobre lo que "es para nosotros" y lo que "no es para nosotros" (Pavcovich, Fatyass, Remondetti, Massafara y Romano, 2013).

21 Fragmento de entrevista realizada a maestra de jornada extendida (2), 2014. 
Los agentes que median bajo esta red intervienen a partir del "seguimiento de casos" familiares que incidirían en la asistencia y en el rendimiento escolar de los/as niños/as, y/o en situaciones de salud particulares:

(...) de la escuela derivamos los chicos al centro de salud, de ahí al área de Niñez del Municerca $\mathrm{N}^{\circ} 4$, de ahí a las Unidades de Desarrollo Regional y sino a la SENAF pero de ahí no se va al juzgado de niñez, vuelve todo de nuevo (...) nos van a decir de nuevo lo mismo, sino tendremos que vestirnos de policía e ir nosotros a las casas o hacer una cacerolazo al gobierno de De la Sota. ${ }^{22}$

Los sentidos y prácticas que estructuran esta red institucional se asocian a lo que Villalta ${ }^{23}$ denomina como nuevas formas de gobierno de la niñez de sectores populares, donde se combina un discurso de derechos con aspiraciones de control social fundamentado en un discurso psicológico y judicial, lo que resulta paradójico si se tiene en cuenta que ha sido derogada la Ley de Patronato de Menores.

Cadena 2): conexión entre la escuela y la iglesia católica del barrio, en la que funciona un Centro de Educación No Formal ${ }^{24}$, donde se despliegan las actividades de apoyo escolar y de seguimiento a las trayectorias educativas de algunos niños/as de la escuela. Lo que resulta llamativo es la manera en que los agentes escolares perciben el trabajo realizado en la capilla como continuación del trabajo pedagógico de la escuela, diluyendo la noción de espacio laico propia de una institución pública.

Según la mirada de una ex voluntaria de la iglesia, se pueden recuperar otras interpretaciones -críticas- sobre este espacio religioso como espacio pedagógico:

\footnotetext{
22 Notas de campo 22, 27-08-2014. Declaraciones de los agentes que trabajan en la red, en el marco de una reunión interinstitucional.

23 Villalta, C., "Estado, familias e infancia. Técnicas de gestión y dispositivos jurídico-burocráticos destinados a la infancia", Clase XIV, Diploma superior infancia, educación y pedagogía, Cohorte 1, FLACSO Virtual, 2014

24 El Centro de Educación No Formal es un proyecto de la Fundación Trinitaria, que nació con un grupo de mujeres que se encargaban del acompañamiento de las tareas escolares de los/as niños/as que asistían a la escuela del barrio.
} 
(...) en el espacio [del apoyo escolar de la iglesia] estaba esto de la neutralidad (...) y pienso que es difícil pensar la educación desde ahí. En ningún momento se planteó esto de las relaciones de dominación o que haya alguna diferencia; estaba el bien y estaba el mal, no importa el contexto, y creo que esa es la mirada judeo-cristiana, entonces nosotros que estamos en la buena te venimos ayudar, es fuerte. ${ }^{25}$

A su vez, es notoria la forma de concebir a los niños y las niñas que participan en el apoyo escolar -al menos discursivamentecomo "débiles", "últimos" y "asistidos"26 -por el voluntario-, en términos similares a como son percibidos por la institución escolar.

Cadena 3): vinculación con la Escuela Especial Número 20 y su equipo interdisciplinario, para el abordaje de los/as "niños/as con problemáticas”. Hasta el 2006 se derivaba a los/as alumnos/as a la Escuela Especial del Instituto del Rosario, derivaciones que se suspendieron, en parte, ante la formulación de la Ley Nacional de Educación 26.206, en la que se define que las escuelas especiales son solo para niños/as con diferentes grados de discapacidades y no para niños/as con problemáticas de aprendizaje.

Lo que interesaba demostrar en el capítulo es el modo en que circulan diferentes miradas en las redes sobre los/as niños/ as de clases populares en tanto alumnos/as, a veces contradictorias entre sí -aquellas que los consideran en igualdad de condiciones con otros estudiantes de escuelas primarias junto a aquellas que los consideran en inferioridad de condiciones asociando la idea de pobres conocimientos para niños/as pobres- y otras que coinciden en una división de estos niños/as de clases populares en situación de pobreza como "carentes de".

\footnotetext{
25 Fragmento de entrevista realizada a ex voluntaria del apoyo escolar de la iglesia del barrio, 2014.

26 Todos estos fragmentos se inscriben dentro del documento oficial del programa de apoyo escolar, "Creciendo con derechos", 2013.
} 

CAPÍTULO V Actos enclasados 

(...) no sé si a estas alturas la docencia es lo que yo quiero, ha ido cambiando mucho la realidad, el contexto, la docencia misma ha ido cambiando (...) uno viene con unas raíces muy fuertes de otra realidad educativa (.... ${ }^{1}$

El efecto de trayectoria social

Como se mencionó los agentes sociales perciben el mundo social tensionando las percepciones en y entre las clases incorporando así principios de división social, jerarquías, llamadas al orden -hechas cuerpo y pensamiento- que suponen actos de enclasamiento que unen y separan según la lógica del "nosotros" y el "ellos". Tal es el caso de este trabajo cuya hipótesis incorpora las lógicas de enclasamiento mediadas por prácticas pedagógicas.

Dentro del espacio de la escuela, se posiciona a las educadoras como agentes institucionales con unas trayectorias docentes particulares en las que han incorporado -diacrónicamente- unas formas de pensar y actuar en el campo escolar.

Este trabajo de objetivar las representaciones, mediante entrevistas semi- estructuradas y abiertas a las educadoras de jornada extendida, posibilita comprender algunos principios orientadores de sus prácticas pedagógicas o la "razonabilidad" de sus puntos de vista, que siendo producto de un habitus particular permite vivir el mundo social sin cuestionarlo.

El punto de partida que da cuenta de los puntos de vista desde los que se construyen las visiones y divisiones sociales de las educadoras de la escuela en estudio con respecto a los niños, las niñas y familias del barrio, se centra no tanto en el efecto de inculcación producto de las trayectorias de clase de las mis-

Fragmento de entrevista realizada a maestra de apoyo, 2013. 
mas $^{2}$, sino más bien en el efecto de trayectoria social propiamente dicho que, como se dijo, impone la representación de la posición ocupada en el mundo social y la visión de este mundo y su porvenir.

El discurso que sostiene esa representación de la posición ocupada en las entrevistadas se construye en relación a una clase media, trabajadora y meritocrática, que se fundamenta fuertemente en la acumulación de capital cultural acreditado por sobre el capital económico.

En el caso de la directora sus recorridos por el espacio educativo dan cuenta de inversiones educativas como parte de estrategias de reproducción de su familia de origen. Desde esta lógica se entiende el paso por varias carrereas terciarias, universitarias y no universitarias, como: Ingeniería en Alimentación -en la Universidad Tecnológica Nacional-, Profesorado en Inglés, Enfermería en dos institutos privados diferentes y finalmente la carrera que concluye, Profesorado en Educación Primaria en el Instituto de Formación Docente Escuela Normal Víctor Mercante -Villa María- de carácter privado. Resulta interesante además la evaluación que hace de su inserción laboral:

(...) yo hice suplencias en la escuela Domingo Faustino Sarmiento para el lado de Alto Alegre, a veinticinco kilómetros de acá de Villa María, y medio año estuve de suplente ahí y me salió el nombramiento en la escuela 20 de Junio, de este otro lado de Tío Pujio, y ahí estuve 8 años, nombrada; yo no tuve que deambular hasta esperar que me nombraran, me ayudó los cursos que había hecho y también las horas ad honorem, yo hice cien horas ad honorem, a la mañana y a la tarde, donde me llamarán yo iba, porque me daba mucho puntaje el ad honorem, esa es la cuestión (...). ${ }^{3}$

La maestra de apoyo o integradora inicia su recorrido cursando dos carreras simultáneamente, Derecho -en la Universidad Nacional de Córdoba- que no finaliza y Profesorado en Educación Primaria, en el Instituto Superior de Formación Docente Nues-

\footnotetext{
2 El efecto de inculcación se analizaría construyendo las condiciones de existencia originales de clase de las educadoras, cuestión que excede al presente libro.
}

3 Fragmento de entrevista realizada a la directora de la escuela (2), 2014. 
tras Señoras de las Mercedes -que es privado y religioso- en Unquillo, Córdoba. Al momento de la entrevista cursa la Diplomatura en Pedagogía Social en la Universidad Nacional de Villa María. Paradójicamente, resulta relevante que considera a las carreras del ámbito universitario como poco rentables y con demasiado "gasto" de tiempo y energía; estas nociones instrumentales sobre la formación pedagógica se observan en las siguientes declaraciones:

(...) estudian tanto tiempo [respecto a los estudiantes universitarios] para terminar dando clases, disculpame que lo diga así, pero eso tiene poca salida [...] por eso yo estudié para maestra. ${ }^{4}$

La docente de la jornada extendida responsable del área Literatura y TICS, Inglés y Artística (maestra 1) también estudió en el Instituto de Formación Docente Escuela Normal Víctor Mercante. Conectándose su historia social-individual con sus condiciones socio-económicas de partida, esta educadora comentó que le hubiese gustado estudiar Derecho, pero no podía viajar a Córdoba para realizar esa formación.

Por su parte, la maestra de Educación Física (maestra 2) realizó sus estudios en el Instituto la Santísima Trinidad de Villa María, de carácter privado; intentó terminar la Licenciatura en la carrera articulada con la Universidad Nacional de Villa María, pero no pudo finalizarla por cuestiones personales ligadas a la maternidad.

Finalmente la docente encargada del campo de Ciencias (maestra 3) llevó adelante su formación en el Instituto del Rosario Profesorado Gabriela Mistral, en Villa María, de carácter privado y religioso.

Retomando la lógica de que quienes se encuentran situados en condiciones de existencia más o menos homogéneas producen sistemas de disposiciones también más o menos homogéneos, se define (en este análisis, al menos discursivamente) la pertenencia a un grupo social que se autopercibe como tal en con-

Nota de campo 12, 30-07-2014. 
traposición a otros grupos o clases sociales. Tal es el caso de las definiciones de estos agentes institucionales que oponen, a las prácticas sociales de las familias de sus alumnos/as, lógicas de distinción social vinculadas al campo educativo (en virtud del capital cultural acreditado y acumulado, que se analizó precedentemente) y al esfuerzo que dicen vivenciar en el campo laboral $^{5}$, como se expone a continuación:

(...) Mi primer trabajo fue en la Estancia Las Margaritas, de julio a diciembre, en los 90 , que es una escuelita de campo que está entre James Craik y los Zorros, ahí daba todo, bah tenía dos grados. Éramos dos maestras, una de las maestras era la directora (...) después de ahí, quince días en la escuela de James Craik, mi pueblo, que son escuelas grandes, después me fui quince días a las Petacas, se llamaba, una escuelita de campo, en Tancacha, (...) 2 años en las Isletillas, un pueblito cerca de Hernando, 3 años y medio en General Deheza en el campo (...). En la escuelita cerca de los Zorros vivía en la escuela con la otra chica y nos llevaban al pueblo la gente de ahí del campo (...). Después en Las Petacas, en Tancacha, si me iba el lunes y me volvía el viernes (...) ahí vivía en la casa del de la cooperadora (...). En las Isletillas, al principio vivía en la escuela con la que era directora, tenía una casita hermosa la escuela, después la directora se jubiló (...) yo sola en la escuela no me animaba entonces empecé a parar en la casa de los chicos, un mes en cada casa (...)Me gustaba mucho, eran otros tiempos, los chicos les interesaba estudiar, que sé yo qué sería, era todo mucho más tranquilo, pero sí con mucho esfuerzo. ${ }^{6}$

(...) Estuve dando clase 3 años en escuelas rurales y tuve como escuela base La Primera Junta, y tenía escuelas en Arroyo Cabral, Tío Pujio, todas desparramadas (...). Viajaba mucho por un campo, por otro, todo el día (...) salía a las tres de la mañana y llegaba a las dos de la tarde reventada,

\footnotetext{
5 Es pertinente mencionar que la mayor parte de las entrevistadas comienzan sus recorridos profesionales en la época de los 90 , en escuelas rurales y, en menor medida, populares, cuyas experiencias de trabajo implicaron mucho esfuerzo pero a su vez son percibidas positivamente, según como son relatadas por los propios agentes institucionales, a diferencia de cómo perciben sus trayectorias docentes en la escuela en estudio.
}

6 Fragmento de entrevista realizada a maestra de jornada extendida (1), 2014. 
porque eran muchas escuelas, tenía 8 escuelas, y al otro 9, $y$ al otro año otra vez $8 .^{7}$

(...) Les cuesta [respecto a los/as alumnos/as de la escuela del barrio] porque no tienen límites de nada, yo por ahí lo veo con las pocas mamás que hablo, hay mamás que se te largan a llorar y te dicen 'ya no sé qué más hacer' (...). Es un trabajo de hormiga, si tenés treinta a los treinta no les va a quedar lo que vos le querés transmitir, a uno le va a quedar o en algún momento más adelante entenderán cómo son las cosas, de tanto machacar y machacar, pero bueno no es que uno pueda esperar resultados o ver cambios ya, por eso te digo, la docencia es como una hormiga viajera (...). ${ }^{8}$

Actos de enclasamiento: lugares comunes y distancias sociales

(...) nosotros en la escuela tenemos que tratar de modificar ciertas cosas, supuestamente para un mejor, una mejor vida de ellos, y ellos van a poner

su resistencia porque es lo que traen de la casa (...) entonces cuesta. ${ }^{9}$

A continuación se retoman las construcciones discursivas de oposición simbólica -el "ellos" que reafirma un "nosotros"- sobre las familias de los/as alumnos/as en referencia al trabajo y al esfuerzo (o punto de vista meritocrático), situadas ambas dimensiones desde la experiencia del espacio escolar.

Así por ejemplo, en el discurso clasista de los agentes institucionales, se interpreta y se define cómo y en qué ámbitos -la escuela o la familia- se deberían llevar a cabo, por un lado, el cuidado y la transmisión de hábitos de conducta a los/as niños/ as y, por otro, la formación intelectual:

(...) a ver, la escuela por sí sola no puede hacer nada: es cincuenta50\% por ciento escuela, cincuenta por ciento50\% familia, compromiso de padres, escuela te forma, papá con-

\footnotetext{
Fragmento de entrevista realizada a maestra de jornada extendida (2), 2014

8 Fragmento de entrevista realizada a maestra de jornada extendida (2), 2014

9 Fragmento de entrevista realizada a maestra de educación física en jornada extendida, 2014.
} 
tiene y ayuda a escuela para que saquemos un sujetito lo más formadito posible, lo más lindo posible (...). ${ }^{10}$

La educación empieza en la familia (...) teóricamente yo acá tendría que venir, enseñarles contenido e irme (...). ${ }^{11}$

(...) ustedes salieron de una panza [hace gestos] son las mamás las que se tienen que hacer cargo de esas cosas, y ustedes tienen que decirles, la escuela está para formar, no para darles todo, nosotros no somos segundas mamás, ustedes vienen a estudiar acá, si no para qué está la escuela, estamos todos locos, si no hay que cerrar la escuela, ustedes ya tienen mamás (...). ${ }^{12}$

Bajo los procesos de enclasamientos sociales, estas educadoras culpabilizan la pobreza ${ }^{13}$ y definen los arreglos de crianza de las familias de clases populares como prácticas de "mal cuidado", caracterizando a dichas situaciones como "violentas y desorganizadas":

(...) es difícil, andan todo el día en la calle, las madres se lo permiten (...) viven amontonados, ven a los hermanos drogándose (...). ${ }^{14}$

(...) En muchas familias están papá y mamá separados, que formaron parejas de nuevo, que tiene $X$ cantidad de chicos y después se juntan los chicos con su pareja nueva, más los niños que traen, porque encima hasta eso, tiene una reproducción tipo conejo, es lo que siempre hablamos, o sea, hay maestras que hace años que vienen luchando para poder quedar embarazadas y no quedan y ven que estos tienen hijos a cantidad sin tener encima la posibilidad económica de sostener todo eso (...) porque vos como padre (...) yo creo

\footnotetext{
10 Fragmento de entrevista realizada a maestra de jornada extendida (2), 2014

11 Fragmento de entrevista realizada a maestra de jornada extendida (3), 2014

12 Nota de campo 26, 16-10-2014.
}

13 Este concepto es adaptado para el caso de la investigación; Catini, Barchetta y Gómez explican la "ilegitimidad social" que los sectores medios atribuyen a los planes sociales y a otras prácticas de las clases populares, que en este caso podrían pensarse respecto al cuidado familiar de los niños y las niñas, como parte de las estrategias de reproducción de estos grupos. En el marco de procesos de distinción entre clases, para el primer caso, los sectores medios suele catalogar la relación entre pobreza y Estado como "asistencial", estigmatizando a los "beneficiarios" mediante el supuesto de que "el que no trabaja o no estudia es porque no quiere" (CATINI, A., BARChetTA, J., y Gómez, A., "El análisis de la pobreza y las intervenciones sobre la pobreza: la complejidad como desafío", Diloretto, M., y Arias, A.J, compiladoras, Miradas sobre la pobreza: intervenciones y análisis en la Argentina posneoliberal, Editorial de la Universidad Nacional de La Plata, 2011).

14 Nota de campo 7, 05-06-2014. 
que ellos se dan cuenta que no les están brindando cosas a sus hijos, no creo que no lo vean a eso, pero bueno, yo creo que los padres se dan cuenta, por eso por lo menos les deben insistir que vayan a comer a la escuela, esas mínimas cosas nomás. ${ }^{15}$

En gran parte estas concepciones esencialistas se basan en una analogía entre la privación económica y la supuesta "privación cultural y moral”. Más allá de que se conocen -más o menos- las condiciones objetivas de pobreza -relativa- de los grupos con los cuales se trabaja, también se los responsabiliza por esa situación, dado que "su cultura" no presentaría los signos propios de la "cultura legítima". Dicho de otro modo, la ausencia de “cultura del trabajo" se debería a "vivir de planes", así como la ausencia de "cultura del estudio" supondría la incapacidad para esforzase y planificar expectativas escolares a largo plazo. Desde estas matrices interpretativas la cultura es vista como un objeto ahistórico y exento de relaciones de poder:

No le repartamos tanto folleto porque no sé si a esta gente le gusta leer. ${ }^{16}$

No les gusta estudiar. ${ }^{17}$

Los chicos no pueden aprender porque ni sus madres les saben hablar. ${ }^{18}$

No hay una cultura de estudio, no hay una cultura de estudio; ustedes que están estudiando saben lo que es estudiar, no cierto, y a lo mejor los mantienen los padres y a lo mejor no pueden ser mantenidos por los padres tienen que trabajar y tienen que estudiar, ustedes saben que si no hacen este estudio el pasito para progresar es esto, ese sacrificio y ellos

\footnotetext{
15 Fragmento de entrevista realizada a maestra de jornada extendida (2), 2014.

16 Nota de campo 22, 27-08-2014.

17 Nota de campo 22, 27-08-2014.

18 Nota de campo 22, 27-08-2014.
} 
no sé si están acostumbrados a ese sacrificio, el estudiar significa un sacrificio (...). ${ }^{19}$

Ellos ya vienen con esa idea, me tienen que dar, me tiene que dar, no te tiene que dar nada [se exalta] te lo tenes que ganar vos, tenes que romperte el alma vos (...). ${ }^{20} 21$

De tal manera se va produciendo una familiarización del conflicto $^{22}$, donde se desconocen -en parte- y, a su vez, se estigmatizan las estrategias sociales de las familias de clases populares, que sin embargo son "razonables" en el horizonte de sus condiciones de existencia, justamente porque son prácticas enclasadas, diferentes a las enclasadas de las educadoras, las cuales obviamente también son producto de las condiciones objetivas que operaron en los efectos de inculcación y que operan en los efectos de trayectorias propios de sus experiencias sociales:

(...) los padres participan muy poco de la escuela, los mandan y no mucho más; yo creo que ellos los mandan como para que sepan leer y escribir pero no tienen mucha más perspectiva, no les interesa si se aprenden otras cosas, no ven a la educación digamos como algo que te abre puertas para una mejor vida (...) además sí acompañan a los chicos hasta tercer grado pero después, después de ahí ya los dejan solos como que creen que los chicos ya son grandes y tienen que arreglárselas (....). ${ }^{23}$

(...) se los manda a llamar, se hacen reuniones y no participan de las reuniones, no les interesa nada (...) yo estando en primer grado, hice tres o cuatro reuniones, nunca tuve el total de madres, cuando es primer grado, que son chiquitos,

19 Fragmento de entrevista realizada a maestra de apoyo, 2013.

20 Fragmento de entrevista realizada a maestra de jornada extendida (2), 2014

21 Se puede agregar que este campo representacional se tensiona, en parte, con el dato objetivo de que la mayoría de los niños y niñas continúan sus estudios secundarios $(70,5 \%)$. Hay un núcleo duro que no se integra al secundario, pero eso debe pensarse como producto de un proceso histórico; la universalización y obligatoriedad de los estudios secundarios está siendo parte de las trayectoria educativas modales de los jóvenes de clases populares recientemente, donde la presencia del Estado es fundamental para continuar este proceso de inclusión.

22 Llobet, V., (compiladora), Pensar la infancia desde América Latina. Un estado de la cuestión, Buenos Aires, CLACSO, 2013.

23 Fragmento de entrevista realizada a la directora (2), 2014 
que tenés que estar encima de ellos, los padres tienen que estar ahí y no nunca tuve, no viene nadie (...). ${ }^{24}$

Colaborar, o sea, son muy pocos, pero si esperan que la escuela les de todo, están acostumbrados [se exalta] a que les dan todo (...). ${ }^{25}$

Cuesta trabajar con los chicos porque cuesta también llegar a los padres (...) esa prepotencia de que te pueden decir y hacer lo que ellos quieren también lo hacen los chicos, es decir, lo hacen los padres afuera y los chicos adentro de la escuela y es muy difícil trabajar así (...). ${ }^{26}$

En los universos simbólicos de las educadoras se considera que cuando el Estado interviene en estos grupos sociales, genera "beneficiarios", “oportunistas" y "vagos", con consecuencias negativas para la vida en la escuela. Esta es la lógica que reproducen, por ejemplo, cuando analizan la Asignación Universal por Hijo:

(...) es como que no le dan interés, no, no valorizan el tener la escuela en el barrio. El Estado, eh, viste, está bien eso de la Asignación Familiar, porque la Asignación Familiar es para el niño en realidad, pero a veces acá las mamás usan la Asignación Familiar porque vienen y te dicen 'Mire, yo hoy no lo mandé porque no tengo zapatillas' u 'Hoy no lo mandé porque no tiene el cuaderno y el lápiz', nosotros le damos lápices, cuaderno, hojas, todo, bueno, o 'No lo mandé porque no tenía jabón en polvo para lavar la ropa' (...) ¡la Asignación es para los chicos, no para la madre! Desvían a veces su Asignación para pagar la luz, para pagar el gas y no salen a laburar, no salen a trabajar (...) yo siempre les digo a los chicos, para tener este pantalón que tengo, ¡tengo que trabajar! No está mal la ayuda del Estado pero, a la par tiene que haber educación, decir, bueno, agarra la pala, saca los yuyos; es todo un combo (...) yo digo, el análisis que nosotros hacemos (...). ${ }^{27}$

Cuál es el mensaje [refiriéndose a la $\mathrm{AUH}$ ] quédate en tu casa, tené críos, tené críos con uno, tené críos con otro, que nadie se haga cargo, total nosotros Estado te bancamos,

Fragmento de entrevista realizada a maestra de jornada extendida (1), 2014.

25 Fragmento de entrevista realizada a maestra de jornada extendida (1), 2014.

26 Fragmento de entrevista realizada a maestra de jornada extendida (1), 2014.

27 Fragmento de entrevista realizada a la directora (1), bajo el proyecto "Prácticas de sectores populares en contextos de pobreza", 2012. 
te aguantamos, y no es así, cuando salgas a laburar, porque yo estoy de acuerdo que el Estado ayude, pero no le des plata gratis, hacé una hermosa fábrica de ropa para todas las entidades que tiene el Estado dando vueltas por el país: ponelos a trabajar, ponelos a coser ropa, ponelos a armar escobas para que puedan limpiar las cosas del gobierno. La Escuela del Trabajo es la única escuela técnica que queda en Villa María, entonces yo por ahí digo, bueno, en esa escuela pueden aprender cosas que les van a servir para vivir y a su vez pueden aprender cosas que les permitan pagarse una carrera, o sea, más allá de que está la Universidad si vos realmente no tenes condiciones económicas para solventarlo podes estudiar igual ahí, pero bueno, mi idea, es por ahí cortar con ese contexto que todo viene de arriba, porque podes hacer cosas vos mismo para subsistir (...). ${ }^{28}$

(...) yo por ejemplo el año pasado como soy suplente llegó diciembre y me quede sin nada, fui a pedir la Asignación por Hijo, me dijeron no, no te corresponde, o sea, todo a mí se me negaba, cuando vos vas trabajás, cumplís con los horarios, hacéss cosas extras para vivir, o sea, te rompés el alma y te lo niegan (...). ${ }^{29}$

En síntesis, estos sistemas de enclasamientos -objetivados en propiedades específicas, incorporados o institucionalizados-, bajo los cuales los individuos "se enclasan y enclasan a los demás", remiten a las relaciones en y entre los grupos y a los puntos de vista sobre el mundo que tienen los agentes de acuerdo al lugar ocupado en el espacio social. Estos esquemas clasificatorios y lugares comunes expresan formas de dominación y oposición, es decir, enuncian la división del trabajo entre las clases sociales y las clases de edades y los sexos.

28 Fragmento de una entrevista realizada a maestra de jornada extendida (2), 2014

29 Fragmento de entrevista realizada a maestra de jornada extendida (2), 2014. 


\section{CAPÍTULO VI \\ Actos de enclasamiento: construcciones sobre los alumnos y alumnas}



(...) tienen que escribir cosas lindas, sobre lo que les da esperanza, que es una palabra que ustedes conocen; porque aunque el país esté mal, con esperanza todo se puede cambiar (...). ${ }^{1}$

La directora le dijo a uno de los niños que su hermano era muy buena persona, tennía buenos vínculos con los otros y era excelente: 'tiene excelente

porque es excelente, se perfila, esas cosas se van perfilando, yo apuesto que va a ser abanderado, apunta para abanderado, en cambio yo con ustedes no apunto a nada, porque si apunto me choco contra el cordón cuneta'. ${ }^{2}$

Con el objeto de abordar los actos de enclasamientos sobre los niños y las niñas estructurados en el espacio escolar, se aplica la noción de transversalidad de lo escolar que permite problematizar interrogantes centrales respecto a qué y cómo se transmite el capital escolar en función del currículum oficial que organiza, conformando redes de sentidos, las prácticas y discursos pedagógicos de los espacios curriculares.

La perspectiva sociológica del trabajo de investigación se centra, específica aunque no exclusivamente, en el cómo de las prácticas analizando los contratos didácticos que remiten a las relaciones entre agentes institucionales y alumnos/as, en cuyas interacciones media una concepción particular de los niños y las niñas de clases populares y del acto educativo en este contexto, que vincula mecánicamente a la pobreza como imposibilidad de que estos alumnos/as aprendan y adquieran conocimientos socialmente valiosos, como se mapeará seguidamente.

\section{Proyectos institucionales}

Retomando la idea de que el proyecto PIIE inserto en la escuela supone la diagramación de un proyecto pedagógico, se recuperan algunos datos y consideraciones, obtenidos desde observaciones, entrevistas y análisis de documentos de la institución,

Nota de campo 6, 04-06-2014.

2 Nota de campo 25, 25-09-2014. 
que hacen al currículum oficial de la escuela, lo cual enmarca -reproduciendo en mayor o menor medida el orden social- diversas prácticas educativas de los agentes institucionales. El proyecto institucional para el período $2014^{3}$, se denomina "Yo puedo, pero juntos podemos más”, el cual se basa en la puesta en funcionamiento de una radio escolar, "Las voces buenas de mi barrio", que se escucha sólo dentro de la escuela.

Según el documento respectivo del proyecto, el mismo surge con el objetivo de generar un espacio de intercambio entre los/as alumnos/as en pos de la participación y el respeto hacia el "otro", para favorecer además el desarrollo de la expresión oral y escrita.

Ahora bien, se observa que para construir el proyecto se parte de las carencias de los/as alumnos/as y no de sus potencialidades e intereses:

[Se parte de] la necesidad de favorecer la alfabetización integral [porque] se observa una característica familiar-cultural que otorga poco valor a la comunicación con la palabra, sobre todo la palabra de los chicos [para que los/as alumnos/as] desarrollen la oralidad, se expresen con claridad y amplíen su léxico $[. ..]{ }^{4}$

Por otro lado, las actividades que incluiría la radio se diagraman en un cronograma previsto en el documento, aunque en el trabajo de campo se detectó que eran mayoritariamente inexistentes. Las actividades de la radio se caracterizan entonces por ser esporádicas e implicar poco protagonismo por parte de los/ as niños/as, los cuales se remiten a leer horóscopos, pronósticos y efemérides. Por otro lado, se aplica la dinámica de "festejar ciertos días", por ejemplo, para el día de la "no-violencia”, así definido por las educadoras, los/as niños/as pegaron hojas

\footnotetext{
3 Años anteriores, para el período 2013, según la información recabada, se trabajó en un proyecto llamado "Un lugar para compartir", que hacía hincapié en el trabajo de convivencia entre los alumnos y alumnas; se observa que, bajo el supuesto de la "falta de límites" y los "problemas de conducta" de los/as niños/as, la escuela considera que este eje debe ser trabajado, incluso en el nuevo proyecto, sin habilitar otros sentidos que no partan de las supuestas carencias de los/as niños/as y que, a su vez, permitan poner en juego conocimientos socialmente significativos.
}

4 Documento institucional “Yo puedo, pero juntos podemos más”, 2014. 
en el pasillo central con frases que habían sido trabajadas, según se observa, sin grandes mediaciones al momento de escribir ciertos sentidos; estas fueron algunas frases recuperadas:

No quiero que haya más guerra en la ciudad.

Me gustaría vivir en un mundo sin delincuencia.

Si no sos violento podés vivir en paz. ${ }^{5}$

El sentido subyacente de la radio es controlar y mantener ocupados, fuera del aula y en los recreos, a los/as "niños/as con problemáticas". En el mismo documento figura el "rol” de algunos alumnos/as -función que mayoritariamente no se cumple en la práctica-, quienes son "seleccionados" por las educadoras, según características particulares con las cuales se los define: "Los alumnos con sobre edad serán los encargados del armado, mantenimiento y seguridad de la radio y también los musicalizadores". 6

Asimismo, como no existe una buena coordinación de las actividades por parte de las educadoras, se desarticula, en definitiva, lo que se enseña en la escuela:

La directora comentó que las maestras no preparan con anticipación las actividades, entonces al momento de la radio los chicos se distraen, se pelean. La radio solo funciona dentro de la escuela, incluso considera que no podría llegar a funcionar en el barrio 'porque sería demasiado para nosotros'. La idea de la radio es trabajar en los recreos con los chicos con sobre edad que tienen problemas "para expresarse". Sin embargo aún no se ha encontrado un lugar adecuado para su funcionamiento. Ni se sabe bien cómo funcionará. El objetivo es que se comente lo trabajado en el aula por materia; empero, según la directora, 'las maestras no están aplicando esto y no están enseñando nada, ni una cosa ni otra, por ejemplo, en el caso de matemáticas'. ${ }^{7}$

Se podría decir que este tipo de proyectos no son planificados por los agentes institucionales porque lo que se prioriza es la obtención de los recursos que brinda el subsidio del PIIE. Este

Nota de campo 26, 16-10-2014.

6 Documento institucional Yo puedo, pero juntos podemos más, 2014.

Nota de campo 4, 23-05-2014. 
programa continúa con la lógica de resignificación que organiza gran parte de las relaciones pedagógicas en la escuela desde un enfoque pedagógico miserabilista: ${ }^{8}$

Esta escuela que tiene el PIIE, es de la nación y se supone [hace un gesto de entre comillas con las manos], se supone, que es para darle más oportunidad a los chicos, una mejora educativa, una enseñanza de más calidad a los chicos, y los que tienen que repetir no tienen que repetir, entonces hay chicos que simplemente no dan, no estudian, no hacen nada y por ahí le tenes que poner una nota igual a uno que hace más o menos algo (...). ${ }^{9}$

Resulta curioso que otro proyecto de la escuela no incluido dentro del PIIE, destinado para segundo ciclo, se dirige nuevamente a "niños/as con problemáticas" como el proyecto anterior. De este modo, se trabaja respecto a los "casos" de sobre edad escolar, inasistencias sostenidas o niños/as que abandonaron recientemente la escuela. El eje general del proyecto apuntaría, mediante un proceso individualizado de "seguimiento de casos", a fortalecer aprendizajes básicos con el fin de disminuir la repitencia, y con ello, el fracaso y la sobre edad escolar. Para alcanzar estas metas, se describen las siguientes actividades:

[...] realizar diagnósticos a los alumnos con sobre edad y dificultades de aprendizaje con el propósito de elaborar las propuestas didácticas coherentes con los datos obtenidos [...] organizar y concretar reuniones informativas con los padres a fin de garantizar el compromiso de los mismos [...] realizar reuniones con el personal docente a fin de acordar estrategias más convenientes según las características de cada alumno [...] confeccionar la planilla de asistencia y realizar encuentros con la familia para fortalecer el compromiso asumido [...] confeccionar recursos didácticos variados

\footnotetext{
8 En Lo culto y lo popular, miserabilismo y populismo en sociología y literatura (1991), Claude Grignon y Jean-Claude Passeron, complejizan la idea de poder simbólico al reconocer que la cultura popular no es producto mecánico de la arbitrariedad cultural dominante, porque en los intercambios históricos entre los grupos, las clases subalternas producen, con relativa autonomía de la estructura de clases, visiones y divisiones del mundo social complejizando la matriz dominante. Se tienen en cuenta entonces las relaciones de re-producción en y entre clases sociales, evitando las explicaciones legitimistas-miserabilistas (que admiten una única dirección del poder) y relativistas-populistas (que descontextualizan las posibilidades de resistencia popular, olvidando inclusive las luchas de clase dentro del mismo grupo).
}

9 Fragmento de entrevista realizada a maestra de jornada extendida (1), 2014. 
que contribuyan en la adquisición y el desarrollo del aprendizaje, que lleven al alumno a aprendizajes acreditables y a fortalecer el autoestima [...]. ${ }^{10}$

En el trabajo de campo no se registraron reuniones de planificación entre el personal docente ni estrategias claras de acercamientos con las familias para realizar los acuerdos de seguimiento conjunto con los/as niños/as. Se entiende que esta situación se debe fundamentalmente a los prejuicios que articulan las tomas de posición de las educadoras, como se analizó en el capítulo V.

Adaptaciones, integraciones, derivaciones y convenios de conducta

El proceso de enseñanza-aprendizaje se estructura, como se concibe en los proyectos institucionales antes mencionados, desde las gramáticas escolares del examen y el registro "necesario para instruir", organizándose -más o menos explícita y sistemáticamente- un campo documental que selecciona y clasifica a un grupo de alumnos/as según categorías jerárquicas y distintivas, que a su vez castiga los grados de "desviaciones" respecto a lo definido como "normal". Estas categorizaciones se basan en las representaciones negativas que las educadoras -desde sus posiciones y trayectorias docentes- construyen respecto a los horizontes educativos probables de estos niños y niñas de clases populares.

Para estos niños/as clasificados según sus "problemáticas de aprendizaje, expresividad y/o conducta”, se implementan las adaptaciones curriculares, o las integraciones, o las derivaciones -poco frecuentes al momento de la investigación-, o los convenios de conducta.

$\overline{10}$ Documento institucional “Aprendiendo juntos”, 2014. 
A continuación, se describen y explican estas diversas prácticas que organizan, distintivamente, las variables de instrucción y de evaluación de los/as alumnos/as.

I) Dentro del espacio de jornada extendida, se pudieron visualizar "casos" de niños/as que en sus trayectorias educativas las educadoras detectan supuestas "problemáticas de aprendizaje y expresividad", por lo cual se realizan las adaptaciones curriculares o adecuaciones estructurales, así definidas por los agentes institucionales.

Estas prácticas combinan el accionar de las docentes, la directora y la maestra de apoyo quienes planifican prácticas y dispositivos para hacer accesible el conocimiento a estos niños/ as. En palabras de ellas el proceso requeriría la participación de los adultos responsables de los/as niños/as, sin embargo son convocados solo a fines informativos sobre cómo se trabajará pedagógicamente.

Las adaptaciones curriculares son definidas de la siguiente manera:

Lo que hacemos nosotros es hacer adaptaciones curriculares, adaptando los objetivos para ese niño, si no es así empezamos a tender redes, que es primero ir al dispensario y buscar la asistencia del psicopedagogo o del psicólogo, primero hay que hablar con los padres y que ellos acepten, que ellos se dirijan a este centro a pedir ayuda, y bueno de ahí empieza todo un camino, que a veces los padres, son los padres los que lo tienen que seguir, no nosotros, pero en el aula siempre está esto de que se trabaja con adaptaciones curriculares mas allá de la respuesta que tengamos o no de las familias (...). ${ }^{11}$

En la práctica, las adaptaciones curriculares dentro del aula ${ }^{12}$ tratan de "hacer más fáciles" los contenidos para que los/as niños/as con "problemáticas" puedan asimilarlos; bajo este

\footnotetext{
11 Fragmento de entrevista realizada a la maestra de apoyo, 2013.

12 Se recuerda que las adaptaciones curriculares por fuera de la escuela, se combinan con el apoyo escolar y el "seguimiento de los casos"; esto supone el trabajo en red entre la escuela, la iglesia del barrio y el dispensario, lo cual fue caracterizado al momento de dar a conocer la diversidad agentes y recursos que se movilizan en y fuera del campo escolar, en el capítulo IV.
} 
perspectiva se incluyen: a) trabajar los mismos temas que los demás alumnos/as pero donde las respuestas "difíciles" vienen del lado de los adultos; b) calificar el desempeño escolar haciendo hincapié en el esfuerzo individual, la buena predisposición del alumno/a y no por sus conocimientos adquiridos; y c) separar a dichos alumnos/as de las prácticas pedagógicas que son consideradas por la docente como valiosas para el resto de los estudiantes, de manera que estos niños/as participan como "niños/as secretarios":

Durante la jornada los niños debían realizar entrevistas a las madres presentes; Javier quiso participar pero se le ordenó que sostenga el micrófono y las preguntas fueron hechas por los mismos niños de siempre (...). ${ }^{13}$

En este punto son alusivas las palabras de Patricio Bolton:

[...] bajo una mirada un tanto reductiva de la situación, los educadores estamos entre la tensión de enseñar contenidos y que 'no apruebe', o 'aguar' contenidos para que tenga el certificado escolar [...] La resignficación curricular y la adaptabilidad de las propuestas educativas en contextos de pobreza, a las situaciones individuales, a los recursos disponibles, a la realidad local, no termina siendo una propuesta institucional pensada e instituida. 'Aguar' contenidos es la salida reinante hoy: 'hacer como si' participara de [...] una adquisición significativa de un saber socialmente relevante, cuando en realidad desde esta postura muchas veces no se hace otra cosa que encerrar, estigmatizar [...] y legitimar la situación. ${ }^{14}$

En definitiva, las adaptaciones curriculares, más allá de las buenas intenciones, implican prácticas pedagógicas que operan "desde-hasta" las dificultades, desconociendo, muchas veces, las potencialidades de cada niño/a y sus intereses por conocer otras cosas complejas:

Las adaptaciones curriculares son plantearse otro objetivo, ver claramente hasta dónde puede llegar cada niño, lo que

\footnotetext{
13 Nota de campo 6, 04-06-2014.

14 Bolton, P., Educación y vulnerabilidad: experiencias y prácticas del aula en contextos diferentes, Op.cit., pág. 40.
} 
es capaz de hacer, entonces en una clase decir bueno tal personita llega hasta acá (...). ${ }^{15}$

II) En el caso de los niños integrados, la dinámica pedagógica se articula con diversos agentes, saberes e instituciones, quienes constituyen un dispositivo cuyas líneas de acción se conjugan para conformar curvas de visibilidad y enunciación ${ }^{16}$, como visión dominante sobre las problemáticas de las infancias de clases populares:

La maestra integradora viene de una escuela especial, una vez a la semana y trabaja con el nene dentro del aula, o sea, con los contenidos que la docente da, no es cierto, porque por ahí se le puede hacer adecuaciones, pero como se está trabajando bien, se está integrando bien, está integrado bárbaro el nene a la primaria, así que yo creo que bueno, a fin de año le dan el alta. Este nene parecía autista por eso le hicieron hacer dos veces el jardín de cinco que no se puede, pero bueno, se hizo toda una fundamentación y aceptaron, no cierto, desde inspección que sí hiciera el jardín, y bueno era, eh no se integraba al grupo, estaba siempre solitario, siempre solo. No son chiquitos con discapacidades, tienen ciertos problemas de aprendizaje [por eso] se adecuan los contenidos a estos chicos (...) o sea, esas dificultades vienen de la casa y se manifiestan después en el aprendizaje (...). ${ }^{17}$ (...) si bien yo podría darte un diagnostico no preciso porque no soy profesional, aproximadamente te pudo decir lo que le pude llegar a estar pasando, pero bueno nosotros necesitamos un diagnóstico profesional para derivarlos al dispensario, quien realiza un informe, entonces es como que nos ayuda, se manda también a la asistente social a las casas (...) algunos tienen problemas de aprendizaje [hace un gesto de exclamación con la mano], algunos tienen problemas graves psicológicos que los manifiestan en las conductas de aprendizaje (...) lo primero que se hace es una reunión de directivos y docentes que estén involucrados en el tema, y después bueno, se los llama al padre, a la madre, tratamos de hablar, de llegar a un acuerdo, tratamos de investigar, hay que tratarlos con pie de plomo a los padres porque no

\footnotetext{
15 Fragmento de entrevista realizada a maestra de apoyo, 2013.

16 Deleuze, G., “Qué es un dispositivo?”, Deleuze, G., Glucksmann, A., Frank, M. y Balbier, E., Michael Foucault, filósofo, Gedisea, 1990.

17 Fragmento de entrevista realizada a la directora de la escuela (1), bajo el proyecto "Prácticas de sectores populares en contextos de pobreza", 2012.
} 
a todos los padres les gusta que por ahí que uno les diga cosas, muchos padres se resisten a creer que sus hijos tienen problemas psicológicos, es como que niegan la realidad, y bueno después se trata de derivar al dispensario, a la asistente social (...). ${ }^{18}$

De esta manera, por un lado, se filtran discursos psicológicos mediante los cuales se interpretan y, a veces, se interviene sobre las infancias de clases populares y, por otro, se desliza el sentido común que reduce a estos niños a necesidades asociadas a carencias que justifican la pobreza de los conocimientos que circulan en la escuela. De tal manera, se articulan lenguajes, vocabularios y paradigmas que van conformando específicos modos de subjetivación. ${ }^{19}$

En definitiva, a la mayoría de los/as alumnos/as de clases populares "no les interesa la escuela" o "les cuesta aprender", simplemente porque "no les da la cabeza"20. De este modo, se extrae al sujeto de su propia historicidad, se lo extrae de los vínculos actuales, de los aprendizajes, y de las posibilidades de transformación.

III) Los convenios de convivencia o de conducta pueden sintetizarse como un conjunto de prácticas disciplinarias que intentan encauzar el orden escolar aplicando micro penalidades sobre niños que tendrían una "carga emotiva" que la escuela no podría contener por lo que deciden "liberarlos" de la jornada extendida y/o derivarlos a otras instituciones extraescolares. Tal es el caso de los llamados "Matones", con cuyas madres se pacta, mediante un acuerdo de palabra con la directora, la no asistencia a estas horas de contra turno:

(...) yo tomé la medida, encubierta, de decir a vos te suspendo, pero es una suspensión (...) bueno vino lo mamá charlamos con la mamá de haber más acompañamiento todo esa cuestión, y bue, empezó a venir otra vez, no fue una echa$\mathrm{da}$, frente a los otros también porque los otros se sentían

\footnotetext{
18 Fragmento de entrevista realizada a maestra de jornada extendida (3), 2014.

19 Fraser, N., "La lucha por las necesidades: esbozo de una teoría crítica socialista feminista de la cultura política del capitalismo tardío", Revista Debate feminista, 1989.

20 Fragmentos de nota de campo 22, 27-08-2014.
} 
muy mal con las cosas que él hacía, porque es un niño que anda mucho en la calle, está muy desprotegido, el hermano más grande que terminó acá, es él que sale a delinquir, él que se droga, tiene una historia detrás él pobrecito que bueno, y la mamá no asume eso, no se da cuenta, no sé, es como que ella dice que no sabe qué hacer (...) bueno nosotros solicitamos que ella vaya a trabajar con la asistente social del dispensario de salud, con la doctora, a ver qué se puede hacer (...). ${ }^{21}$

Estos discursos y prácticas se tensionan con aquellos inclusivos presentes, por ejemplo, en el PIIE. Se apela a la idea de la contención, pero no se problematizan ni la noción de contención, ni la noción de inclusión:

Nosotros lo contenemos, lo contenemos, el año pasado lo contuvimos bastante, este año se nos está haciendo más difícil porque según versiones de los chicos y yo lo he visto en la plaza, no lo he visto fumar porro pero sí lo he visto con el grupo de muchachos que se juntan en la plaza (...) él viene acá a la mañana viene con toda un carga emocional que le cuesta integrarse, es todo un tema, un trabajo de qué se hace, de que lo charlas qué sé yo porque él tiene otros intereses, no está en el nivel primario (...) son Matones digamos, le decimos nosotros como que quieren imponerse al más débil, hay chiquitos que son buenísimos, es como que les quieren hacer pagar como peaje, es muy feo lo que estoy diciendo pero es así, entonces trabajamos con las reglas de convivencia, yo soy de ir hablar mucho con ellos (...). ${ }^{22}$

Así se van contraponiendo los discursos de inclusión y las experiencias de exclusión, que van marcando las trayectorias potenciales de algunos niños del barrio.

IV) Por último, las derivaciones a otras escuelas suponen los fracasos de los contratos didácticos, asociados a problemáticas de discapacidad o a problemáticas psicológicas, que se cierran en torno a los casos "punto final", según la directora, tal es la situación, por ejemplo, de un grupo de niños llamados los "Lobos":

21 Fragmento de entrevista realizada a la directora de la escuela (2), 2014.

22 Fragmento de entrevista realizada a la directora de la escuela (2), 2014 
(...) los "Lobos", así llamados los chicos que fueron sacados de la escuela del barrio por "mal comportamiento"; actualmente están en otras escuelas en donde según las maestras: 'roban, amenazan a la gente, lo mismo que hacían acá, mienten, ¡les mandamos a los Lobos [risas]! (...). ${ }^{23}$

\section{Caracterizando a la jornada extendida}

En la jornada extendida se inserta el trabajo de investigación-intervención en la escuela, más particularmente, en el campo de Artística. En este caso, interesa mostrar los lineamientos, su organización y algunas prácticas y discursos que hacen a la lógica de este programa y a sus campos de formación.

Según la Ley de Educación Nacional ( $\left.\mathrm{N}^{\circ} 26.206\right)$ en su artículo 28, establece que: “Las escuelas primarias serán de jornada extendida o completa con la finalidad de asegurar el logro de los objetivos fijados para este nivel por la presente ley".

Esta legislación se articula con la obligación de las provincias de poner a funcionar la jornada escolar completa. Según la Ley de Educación Provincial ( $\mathrm{N}^{\circ}$ 9.870), se destaca la finalidad de:

Asegurar la escolarización de todas las niñas y niños en la educación de nivel primario y secundario en condiciones satisfactorias [...] Aumentar, hasta alcanzar el ciento por ciento $(100 \%)$ el número de escuelas primarias de jornada extendida o completa, principalmente en el segundo ciclo, a fin de favorecer una mejor articulación con el nivel secundario dentro de los próximos cinco (5) años, para lo cual se prevé la incorporación de trescientas noventa y ocho (398) escuelas primarias en programa de jornada extendida.

Según documentos oficiales ${ }^{24}$ jornada extendida presenta un desafío al poner en movimiento transformaciones vitales para las escuelas, los modos de pensar lo que se enseña, la organiza-

\footnotetext{
23 Nota de campo 22, 27-08-2014. Reunión entre varias instituciones del barrio, que conforman parte de las redes con las cuales trabaja la escuela.

24 Estos datos se extraen del Documento Oficial de Jornada Extendida, Ministerio de Educación de la Provincia de Córdoba, 2010.
} 
ción de los contenidos curriculares y de los tiempos didácticos. Debería ser un espacio para repensar la organización escolar con nuevas ofertas curriculares articuladas en los campos de Literatura y TICS, Ciencias Naturales, Lengua Extranjera, Educación Física y Expresiones Artísticas y Culturales. Debería habilitar otros modos de "estar en la escuela" y no otra instancia de espera para "irse de la escuela", como se da en este caso empírico.

El acompañamiento a los docentes de las escuelas se realiza a través de instancias de capacitación y asistencia técnica, empero, estas se superponen con las actividades de jornada extendida, lo cual hace que la sistematicidad y planificación de las actividades en el tiempo sean difíciles de sostener.

El taller sería la modalidad de trabajo pedagógico privilegia$\mathrm{da}$, en pos de permitir una posición activa de los agentes con respecto a la construcción de conocimientos, su acceso, circulación y socialización. Sin embargo, en esta escuela se observa que no se "rompe" con la lógica clasificatoria de los cuerpos, tiempos, espacios y relaciones respecto al saber en el aula.

A continuación se sintetizan las actividades que proveen los campos de formación de jornada extendida y se comparan con las prácticas efectivas que circulan en los espacios curriculares.

\begin{tabular}{|l|l|l|}
\hline & $\begin{array}{l}\text { Lo provisto por } \\
\text { el programa de } \\
\text { Jornada Extendida }\end{array}$ & $\begin{array}{l}\text { Prácticas efectivas en } \\
\text { Jornada Extendida }\end{array}$ \\
\hline Literatura y & $\begin{array}{l}\text { El eje es el trabajo } \\
\text { grupal e individual } \\
\text { utilizando múltiples } \\
\text { materiales y } \\
\text { soportes de lectura } \\
\text { que incluyan a las } \\
\text { TICS para ampliar } \\
\text { el marco de } \\
\text { interpretación de la la } \\
\text { realidad. }\end{array}$ & $\begin{array}{l}\text { Devaluación de la } \\
\text { literatura y del formato } \\
\text { TICS; se copian textos en } \\
\text { las computadoras: } \\
\text { “En cuanto a literatura y } \\
\text { TICS, según la maestra le } \\
\text { es más fácil dar la clase, } \\
\text { ya que 'los chicos se } \\
\text { entretienen pasando cosas } \\
\text { en las compus'”.1 }\end{array}$ \\
\hline
\end{tabular}




\begin{tabular}{|c|c|c|}
\hline Ciencias & $\begin{array}{l}\text { El objetivo es el } \\
\text { fortalecimiento de } \\
\text { los conocimientos } \\
\text { y capacidades } \\
\text { científicas. }\end{array}$ & $\begin{array}{l}\text { Devaluación de las } \\
\text { capacidades e intereses } \\
\text { de los/as niños/as por } \\
\text { aprender ciencia: } \\
\text { “ (...) uno trata de } \\
\text { buscarles contenidos } \\
\text { que sean amenos y en } \\
\text { la parte de ciencias que } \\
\text { puedan ser experiencias, } \\
\text { que no sea teóricas, nada } \\
\text { teóricas, todo a través de } \\
\text { experiencia, bueno no, } \\
\text { no, dos experiencias en un } \\
\text { mismo día es como darles, } \\
\text { en la segunda experiencia } \\
\text { ya empiezan a jugar, } \\
\text { ya rompen las cosas, te } \\
\text { empiezan a decir ¿cuánto } \\
\text { falta?, o sea, tenerlos, } \\
\text { contenerlos hasta las dos } \\
\text { de la tarde es realmente } \\
\text { difícil, también es } \\
\text { agotador para el docente } \\
\text { (...)”.² }\end{array}$ \\
\hline $\begin{array}{l}\text { Expresiones } \\
\text { artísticas y } \\
\text { culturales }\end{array}$ & $\begin{array}{l}\text { El eje es la } \\
\text { disposición de los/ } \\
\text { as niños/as para el } \\
\text { uso de los distintos } \\
\text { lenguajes para } \\
\text { la expresión y la } \\
\text { creación, desde una } \\
\text { perspectiva crítica y } \\
\text { trasformadora. }\end{array}$ & $\begin{array}{l}\text { La clase se transforma } \\
\text { en "prácticas de } \\
\text { manualidades", con } \\
\text { escasos materiales, con } \\
\text { procesos inconclusos y } \\
\text { nula puesta en juego de } \\
\text { creatividad de los niños. }\end{array}$ \\
\hline $\begin{array}{l}\text { Lengua } \\
\text { extrajera y } \\
\text { TICS }\end{array}$ & $\begin{array}{l}\text { Se busca promover } \\
\text { la participación } \\
\text { en situaciones } \\
\text { de interacción } \\
\text { comunicativa con el } \\
\text { idioma inglés. }\end{array}$ & $\begin{array}{l}\text { Transcripción de textos } \\
\text { al formato digital } \\
\text { y memorización de } \\
\text { canciones. }\end{array}$ \\
\hline
\end{tabular}




\begin{tabular}{|l|l|l|}
\hline $\begin{array}{l}\text { Prácticas } \\
\text { corporales y } \\
\text { locomotrices }\end{array}$ & $\begin{array}{l}\text { Se basa ofrecer un } \\
\text { espacio y tiempo } \\
\text { institucional en el } \\
\text { cual el estudiante } \\
\text { construya } \\
\text { aprendizajes válidos } \\
\text { en el campo de lo } \\
\text { cultural, social, } \\
\text { corporal, motriz y } \\
\text { lúdico. }\end{array}$ & $\begin{array}{l}\text { Reproducción de las clases } \\
\text { de educación física de la } \\
\text { modalidad tradicional; } \\
\text { separación de cuerpos por } \\
\text { sexo: } \\
\text { “(...) los chicos no tienen } \\
\text { ganas de aprender, ellos } \\
\text { quieren ir directamente } \\
\text { a jugar y todo lo que sea } \\
\text { correr, correr, correr, } \\
\text { o sea, no una situación } \\
\text { donde yo los tengo que } \\
\text { poner a pensar sobre } \\
\text { cómo resolver algo, me } \\
\text { entendés, ellos quieren } \\
\text { correr, jugar al futbol es lo } \\
\text { prioritario (...)”.3 }\end{array}$ \\
& \multicolumn{2}{|l}{} \\
& &
\end{tabular}

Nota de campo 1, 29-04-2014.

Fragmento de entrevista realizada a maestra de apoyo, 2013.

Fragmento de entrevista realizada a maestra de jornada extendida (2), 2014.

De tal manera, según las educadoras, no están dadas las condiciones de posibilidad para llevar adelante este programa, cayendo nuevamente en una oferta pedagógica reducida a la idea de contención social:

(...) en jornada es tratar de hacer cosas que no se haga [en el formato tradicional] pero se complica porque encima son dos horas, y son dos horas que los chicos vienen de estar toda la mañana en la escuela, llega el medio día, quieren comer y se quieren ir, muchos chicos se nos escapan, o sea, es una idea que no funciona, o sea, habría que implementar otra cosa porque es cierto los chicos llegan cansados, y entre que no les interesa y llegan cansados se complica (...). ${ }^{25}$ (...) no es fácil la jornada extendida, dos horas es muy difícil contenerlos, ellos a la hora ya están cansados, ya se quieren ir. La realidad es que ellos se quieren ir, no importa lo que vos tengas, no importa si vos venís con diez actividades diferentes, ellos vieron tele y ya se quieren ir, ya no están

$\overline{25}$ Fragmento de entrevista realizada a maestra de jornada extendida (2), 2014 
en condiciones de atender, son chicos que viven totalmente libres de horarios entonces la escuela los ata. No sé, más que para la contención la jornada extendida en estos momentos, la realidad es esa (...). ${ }^{26}$

En conclusión, los proyectos educativos y espacios curriculares analizados se organizan desde las construcciones de sentido de los agentes institucionales, centrándose las prácticas pedagógicas en la lógica del "desde-hasta las dificultades", proyectando la profecía de repetición de las trayectorias educativas modales de los padres y madres ${ }^{27}$ de los/as niños/as. De allí que las propuestas se asocian con lo posible y lo útil para la vida en el barrio de estos "pobres alumnos/as". ${ }^{28}$

Ana Abramowski, en su texto Los afectos magisteriales: el problema de amar a los niños ${ }^{29}$, analiza los procesos bajo los cuales la educación desplaza la centralidad del conocimiento socialmente válido y de la cultura intelectual. Esto lleva a pensar los problemas de los/as niños/as en la escuela en clave individual y psicológica y partiendo de sus "carencias" y "necesidades de", impidiendo que se desarrollen proyectos políticos-pedagógicos y colectivos de cambio, por medio de los cuales se problematice qué y cómo se enseña-aprende en la escuela.

\footnotetext{
26 Fragmento de entrevista realiza a maestra de apoyo. 2013.

27 Cuyas trayectorias modales para el caso de la población adulta fueron, en su mayoría, incompletas en el nivel primario y, especialmente, en el secundario, como se explicitó en el capítulo III.

28 En este punto una de las actividades centrales que organizó el año educativo examinado fue el trabajo en la huerta realizada en el patio de la escuela, cuyo proceso -inconcluso- se mostró en el marco de la feria de ciencias. Año tras año se sigue trabajando con la huerta, incluso cuando las propias educadoras consideran que el proceso no es significativo, pero sin embargo permitiría que "niños pobres consigan sus alimentos".

29 Aвramowski, A., "Los afectos magisteriales: el problema de amar a los niños", Clase XI, Diploma superior infancia, educación y pedagogía, FLACSO Virtual, 2014.
} 

CAPÍTULO VII

La matriz institucional 

Lo que ustedes necesitan son límites, esos tiene que ser puestos en la casa y reforzados en la escuela, nosotros los adultos los tenemos que guiar (...). ${ }^{1}$

La matriz institucional, tal como se explicitó en el capítulo II, como cultura institucional, como exteriorización de lo interno, como ejercicio de la función de legitimación del orden social, se define por los ritmos, tiempos, espacios, rutinas, representaciones, control de los cuerpos y lo imprevisto escolar.

A continuación se muestra cómo los contratos didácticos² -antes analizados-reflejan el currículum amplio y oculto, permeando todas las prácticas en la escuela y estructurando determinados contratos sociales que subordinan a los niños y las niñas a la matriz adultocéntrica y sociocéntrica ${ }^{3}$ de los agentes institucionales.

Las prácticas y discursos educativos son eficaces socialmente porque se respaldan en la autoridad pedagógica de quienes llevan a cabo las acciones pedagógicas, supuestamente sin connotaciones políticas, ni sociales. Esta autoridad permite a los agentes institucionales legitimar ciertas reglas, estableciéndose -aunque no linealmente- qué y cómo se puede decir y hacer en la escuela.

\footnotetext{
Nota de campo 6, 04-06-2014.

2 Se recuerda que los contratos didácticos permiten examinar las relaciones entre agentes institucionales y alumnos/as, según la intencionalidad y la significatividad de la práctica docente y la explicitación -o no- del proceso de enseñanza-aprendizaje hacia el/la alumno/a.

3 Los agentes institucionales en tanto adultos, se refugian en la categoría de "la" experiencia -como conocimiento acumulado a lo largo del tiempo, que también supone posiciones de clase- y desde allí prohíben, aconsejan y autorizan, impactando -desde diferentes dispositivos- en la construcción de subjetividades de las infancias. Esto constituye la matriz adultocéntrica y sociocéntrica bajo la cual se estructuran las relaciones intergeneracionales, entre "los más viejos" y "los recién llegados". Eduardo Bustelo habla de la heteronomía conformada por valores socialmente hegemónicos que se intentan imponer a los niños y las niñas. Bajo esta perspectiva los/as niños/as son vistos como un continuo de la transmisión automática de la adultez. Los agentes institucionales podrían representar según esta visión la heteronomía hegemónica del statu quo (Bustelo, E., El Recreo de la infancia, argumentos para otro comienzo, Buenos Aires, Siglo Veintiuno Editores, 2011).
} 
Desde otros planteos teóricos se reconoce que el educador además goza de su posición de adulto. Eduardo Bustelo reflexiona sobre una asimetría adultocéntrica que va oponiendo y definiendo categorías en los/as niños/as según formas particulares de reconocimiento o rechazo, enunciándolos, en términos generales, como sujetos dependientes, incompletos y vulnerables.

La autoridad se convierte entonces en una de las principales gramáticas escolares para el caso estudiado; representa el foco local del poder o el principio de poder-saber organizador de las relaciones dentro de este ámbito escolar.

Ahora bien, dadas las tensiones de clase entre el trabajo pedagógico secundario y el primario, debido a la distancia cultural que las educadoras oponen a las condiciones de clase de los niños y las niñas, la relación pedagógica se vacía y así los agentes institucionales consideran, en términos generales, que los/ as alumnos/as "no van aprender"4. La autoridad pedagógica como tal instituye una arbitrariedad cultural y en este caso, además, va constituyendo un habitus escolar asentado en lógicas de control social:

La directora señaló el mal comportamiento de algunos niños, haciendo mención a uno de ellos con nombre y apellido, diciendo: 'que mal educado que sos, me tenes harta, sos desafiante como en tu casa' (...). ${ }^{5}$

(...) ellos son re hábiles para casarte al vuelo, la autoridad es muy importante, porque ellos no la tienen desde su casa y eso de la autoridad, se va ganando con el tiempo (...). ${ }^{6}$

(...) acá las órdenes las doy yo, que les quede claro, al que no le gusta que se vaya (...). ${ }^{7}$

Entendiendo que el poder es una relación social, los educandos, en algunas ocasiones, tensionan la red de sentidos de su

\footnotetext{
Asimismo, se podría conjeturar que los niños y las niñas y sus familias tampoco reconocen a la escuela como un espacio legitimo de aprendizaje o, al menos, como un espacio "para nosotros" dado esta distancia cultural impuesta en la relación de dominación.

5 Nota de campo 6, 04-06-2014.

6 Fragmento de entrevista realizada a maestra de jornada extendida (3), 2014.

7 Nota de campo 25, 25-09-2014.
} 
espacio escolar, con aquello que le es significativo hacer desde su experiencia infantil. Tal como dice Corsaro: “niños/as no reproducen el orden adulto sin más, sino que lo producen en un proceso en donde re-elaboran, interpretan y crean un nuevo orden de significaciones en una cultura entre pares". "La indisciplina" puede significar otras formas de habitar el lugar, de seguir estando en la escuela, de soportar ese espacio o incluso "pasarla bien"; a pesar de que el contexto comunicativo no posibilite apropiarse de los bienes culturales “legítimos” y participar activamente, los/as niños/as encuentran formas "para seguir estando".

Tiempos y espacios escolares

En este marco, la escuela ejerce una acción normalizadora sobre las prácticas de los alumnos y las alumnas, en el espacio y el tiempo escolar, cuya estrategia de control y regulación, en ocasiones, es confrontada por estrategias de resistencia y resignfiicación por parte de estos últimos.

Los espacios escolares transmiten mensajes estéticos, sus objetos están cargados de una serie de valores, representaciones y sentidos que pueden ser -más o menos- decodificados por los sujetos que se vinculan con dichos objetos en determinados contextos. ${ }^{9}$ Según Brailovsky, ${ }^{10}$ los objetos escolares ${ }^{11}$ inscri-

8 Bustelo, E., "Notas sobre infancia y teoría”, Clase VI, Diploma superior infancia, educación y pedagogía, Cohorte 1, FLACSO Virtual, 2014.

$9 \quad$ Eco, U., La estructura ausente, Buenos Aires, Lumen, 1981.

10 Brallovsky, D., "Los objetos escolares en la infancia”, Clase X, Diploma superior infancia, educación y pedagogía, FLACSO Virtual, 2014

11 Los objetos escolares, según Brailovsky (2014), invitan a reconocer aquellos objetos que habitan lo cotidiano escolar, que en ocasiones están invisibilizados, pero son relevantes en la constitución de la experiencia de la alumnidad. Se pueden destacar pizarrones, cuadernos, libros, campanas, banderas, guardapolvos, mapas, pero también reglas y rutinas escolares. Estos objetos ayudan a los alumnos a trabajar de alumnos tal como se espera que lo hagan, aunque también "pueden cumplir una función disruptiva y propiciar una experiencia de antialumnidad [...] medios para que los chicos reconstruyan o elaboren críticamente su posición como alumnos" (BrallovskY, D., "Los objetos escolares en la infancia”, Clase X, Diploma superior infancia, educación y pedagogía, FLACSO Virtual, 2014). 
ben marcas ideológicas, actitudes y connotaciones pedagógicas que definen lugares de habilitación o subordinación en los/as alumnos/as y en los educadores. Cuando el espacio es habitado, según los sentidos que le otorgan los agentes, los objetos se convierten en instrumentos de disciplina -en sentido foucaultiano- y significan particulares experiencias. En este caso, las estéticas específicas de la escuela se relacionan con objetos materiales y prácticas caracterizadas por tonos de obligación.

En el aula, el ritual de inicio esta mediado, generalmente, por la queja constante de la docente hacia los/as alumnos/ as porque "no traen los materiales (...) no hacen la tarea (...) son unos mal educados"12. Por ejemplo, la presentación de la maestra -con el cuerpo tenso y la voz exaltada- es una forma de culpabilizar a los/as niños/as respecto a que "la clase no se pueda dar como debería ser":

Comenzó la clase con la "ritual presentación": ‘a ver si se callan de una vez, no cambian más ustedes, harta me tienen, son grandes para portarse así, yo no tengo problema si no quieren trabajar agarran sus cosas y se van, luego yo tengo que evaluar, ustedes saben lo que tiene que hacer'. La maestra continuó repitiendo que no iba a comenzar la clase, que por ella se iba a tomar un café hasta que el tiempo pase $(. ..) .^{13}$

¿Qué, no trajeron los materiales? Así no se puede trabajar, quieren que les traigan todo, no tienen nada' (...). ${ }^{14}$

Estas prácticas escolares violentan la posición de subordinación social de los/as niños/as, en tanto pertenecientes a clases populares en situación de pobreza, así como en tanto niños/as, situándolos en una particular autonomía relativa, como si fueran adultos pequeños; como si fuera responsabilidad de ellos/as asegurarse las condiciones para su escolaridad y supervivencia:

(...) aunque esos chicos tengan más dinero [respecto a otros niños/as de escuelas del centro] en el caso de ustedes, son ustedes los que les tienen que exigir a las madres que cuan-

Fragmentos de nota de campo 2, 8-05-2014.

Nota de campo 5, 29-05-2014.

14 Nota de campo 11, 24-07-2014. 
do cobran la Asignación Universal que es por hijo, les compren los útiles, los guardapolvos, para eso es la Asignación, no pueden venir con excusas de que no tienen las cosas para la escuela (...). ${ }^{15}$

Por su parte, el tiempo escolar es controlado por las maestras, impidiendo que las prácticas pedagógicas se sostengan en un tiempo productivo, menos aún como un tiempo de disfrute con el conocimiento y con el saber: ${ }^{16}$

(...) mientras corríamos y nos congelábamos [jugando a la mancha congelada], apareció el grito de la maestra, diciendo que ella ya se había cansado de llamar la atención, que ya se había terminado la actividad, que se tenía que ir (...) yo me quede sorprendida junto con otros niños; uno de ellos le quiso explicar que estaban dentro del juego, que no se estaban portando mal, pero ella cerró la actividad. Ante mi cara de asombro, un nene me dice 'sí, a esta hay que tenerle miedo, es brava', refiriéndose a la maestra (...). ${ }^{17}$

Los procesos pedagógicos no se sostienen en el tiempo ya que se interrumpen o suspenden constantemente. Las prácticas pedagogías se improvisan dado que subyace el supuesto de que a los niños y las niñas de clases populares "no les interesa la escuela", asisten, en parte, porque "los mandan en búsqueda de la comida" 18 .

Las horas libres también son controladas, más allá de la existencia de dos recreos formalmente, estos se suspenden o se autorizan según el comportamiento -adecuado o no para las reglas escolares- ${ }^{19}$ que los/as niños/as tengan dentro del aula. En varias ocasiones, los/as alumnos/as salen al recreo cuando la docente no los puede contener, es decir, el espacio de dis-

\footnotetext{
15 Nota de campo 26, 16-10-2014.

16 En muchas ocasiones, la impresión que se generaba desde los procesos de observación en el trabajo de campo, remitía a una lógica de "hacer actividades para que se pase la hora y los chicos no se porten mal".

17 Nota de campo 2, 8-05-2014.

18 Fragmentos de nota de campo 1, 29-04-2014.

19 Entre ellas se pueden mencionar: "No romper los árboles, no correr, no gritar, no matar seres vivos, no jugar a lo bruto, jugar despacio, respetar a los mayores, cantar con orgullo el himno, no ensuciar, cerrar la canilla, no tirar basura, no mojar los espejos", entre otras (Notas de campo 2 y 26, 2014).
} 
frute del recreo y del juego son parte de las gramáticas escolares de vigilancia ${ }^{20}$.

Como sobró tiempo la maestra nos dijo que los "saquemos" [a los /as niños/as] afuera para hacer algún juego (...) La maestra explicó: 'salimos al patio pero en orden, el que se porta como un mal educado vuelve al aula' (...). ${ }^{21}$

Otras formas de control registradas se relacionan con el manejo sistemático sobre los cuerpos infantiles, así el guardapolvo se puede convertir en un dispositivo de normalización-homogenización:

(...) la docente le llama la atención a una niña que estaba con pollera y calza: 'a ver vos no te hagas la viva, aprendé a leer y a escribir primero, además dónde crees que estás para venirte así, estamos en la escuela, no te podés venir con ropa de calle, después cuando los chicos le dicen algo, ay pobrecita ella, no, no es así, acá se viene con guardapolvo, ese es el uniforme mínimo que les pedimos' (...) en ese momento ingresa la directora y agrega: 'acá se viene con guardapolvo, yo siempre vengo con chaquetilla aunque haga calor, no se pueden venir como quieran, tienen que entender esto chicos, después cuando salen a la Medioteca se ven distintos a los otros, son ustedes los que se discriminan, por qué en [nombra a otras escuelas del centro] esos chicos van vestidos como corresponde cuando salen a hacer esas visitas y los de [nombra al barrio] no, son ustedes los que se discriminan apareciendo como diferentes' (...). ${ }^{22}$

En el caso de los rituales asociados a la bandera, este símbolo se constituye como un dispositivo de diferenciación, ya que los "elegidos" siempre son los mismos, mayoritariamente mujeres, que obligatoriamente deben tener puesto el guardapolvo blanco.

El dispositivo de gratificación-sanción foucaultiano además está presente como herramienta correctiva personalizada en algu-

\footnotetext{
20 Como se expuso en el marco teórico, las gramáticas de escolaridad posibilitan reconocer los estilos pedagógicos, en este caso, centrándose en el control escolar que determina el "comportamiento esperado" frente a lo clasificado como "comportamiento desviado" (CRIAdo, M.e., La escuela sin funciones. Crítica de la sociología de la educación crítica, España, Bellaterra, 2010).
}

21 Nota de campo 11, 24-07-2014.

22 Nota de campo 26, 16-10-2014. 
nas de las niñas de la jornada extendida, ${ }^{23}$ a quienes se les niega la fruta que es parte del menú que deben ofrecer en el comedor de la escuela ${ }^{24}$. Esto constituye un medio ejemplificador para los otros niños/as, quienes son gratificados por el acto de llevarse la fruta, el cual se refuerza frente al castigo de las compañeras que fueron privadas de la misma:

Antes de irse la docente y la directora ordenaron hacer una fila para entregar unas naranjas. La docente notó que algunos se atropellaban entre ellos para agarrar la naranja con el apuro de irse. Se enojó nuevamente con Brenda, la cual decidió irse sin mirarla, sin decirle nada, con cara de enojada, sin saludarnos, sin la naranja (...) en varias oportunidades la docente y la directora se refirieron a esta niña del siguiente modo: 'es igual a la prima, unas mal habladas' (...). ${ }^{25}$

Frente a esto, sin embargo, no son pocas las veces que los/ as niños/as encuentran respuestas, gestos, silencios para resistirse a las interpretaciones etnocéntricas y adultocéntricas de las maestras:

Los niños se retiraron contentos a los gritos, pidiendo sus naranjas; las maestras dijeron: 'bueno chicos parecen muertos de hambre ya se las van a dar'; se repartieron las naranjas, ordenado que hicieran una fila; Brenda estaba fuera de ella entonces tuvo un enfrentamiento nuevamente con la docente: 'Brenda dejá de molestar, hacé la fila o no vas a comer naranja y te vas'; en varias oportunidades se repitió esto; Brenda solo miraba a la maestra; 'a mí no me vas a mirar así, te vas a tu casa', dijo la docente; 'bueno me voy, no me voy a morir por una naranja', dijo Brenda. ${ }^{26}$

Otro nene comentó que no le alcanzaba la plata para comprar los materiales, la respuesta de la maestra fue: 'bueno que tú mamá salga a trabajar'; el nene dijo, 'mi padrastro no está porque trabaja'; 'y bueno', dijo la maestra, 'no te-

\footnotetext{
23 En este caso, para entender las prácticas enclasantes de las maestras, cabe resaltar que mediante el trabajo de campo se observó que este grupo de niñas pertenece a las familias con menos recursos dentro del territorio en cuestión.

24 Se recuerda que en la escuela funciona el Programa de Asistencia Integral de Córdoba de carácter provincial, que brinda el desayuno y el almuerzo en instituciones educativas insertas en contextos de vulnerabilidad.
}

25 Nota de campo 11, 24-07-2014.

26 Nota de campo 25, 25-09-2014. 
nes excusa'; y el nene le respondió, 'pero no alcanza la plata'; 'bueno, bueno, entonces hacé algo vos, así no se puede', le contestó la maestra. ${ }^{27}$

Las tácticas de escamoteo ${ }^{28}$ como alteración de usos y significados pueden observarse en prácticas de los/as niños/as, por ejemplos: haciendo comentarios y chistes por lo bajo; poniéndose la gorra cuando "la maestra no te ve"; saliendo de la formación de la bandera porque "hace calor al sol" y/o evitando pasar al frente porque "hace frio para sacarse el buzo"29. Lo anterior podría interpretarse en la lectura que Ramíre ${ }^{30}$ hace de Foucault, desde las nociones de técnicas de producción de sí mismo, cuidado de sí, como formas de subjetivación que producen los sujetos con relativa autonomía de las relaciones de poder; ejercicios de la libertad sobre el arte de la existencia que permiten escapar al control sobre la vida.

Los niños y las niñas entonces encuentran formas en las que negocian la imposición de visiones y divisiones sociales respecto a sus posiciones como niños o niñas de clases populares; producen sentidos particulares sobre sus identidades individuales y repertorios de una cultura entre pares; se apropian de tiempos y espacios en los contextos educativos en los cuales participan; y utilizan de maneras diversas recursos discursivos y no discursivos cuyas prácticas y sentidos atraviesan y tensionan las

\footnotetext{
$27 \quad$ Nota de campo 2, 8-05-2014.

28 Según De Certeau (2000), en su texto La invención de lo cotidiano: “llamo táctica a la acción calculada que determina la ausencia de un lugar propio [...] La táctica no tiene más lugar que el del otro [...]. No tiene el medio de mantenerse en sí misma, a distancia, en una posición de retirada, de previsión y de recogimiento de sí: es movimiento 'en el interior del campo de visión del enemigo', como decía Von Bülow, y está dentro del espacio controlado por éste. No cuenta pues con la posibilidad de darse un proyecto global ni de totalizar al adversario en un espacio distinto, visible y capaz de hacerse objetivo. Obra poco a poco. Aprovecha las 'ocasiones' y depende de ellas, sin base donde acumular los beneficios, aumentar lo propio y prever las salidas. No guarda lo que gana. Este no-lugar le permite, sin duda, la movilidad, pero con una docilidad respecto a los azares del tiempo, para tomar al vuelo las posibilidades que ofrece el instante. Necesita utilizar, vigilante, las fallas que las coyunturas particulares abren en la vigilancia del poder propietario. Caza furtivamente. Crea sorpresas. Le resulta posible estar allí donde no se le espera. Es astuta." (De CerTEAU, M., La invención de lo cotidiano I. Artes de hacer, Op.cit., pág. 43).

29 Fragmentos de nota de campo 5, 29-05-2014.

30 Ramírez, M.L., "La Ética, práctica de la libertad en Michael Foucault", El saber filosófico 2, sociedad y ciencia, Martínez Contreras, J., y Ponce de León, A., (compiladores), Siglo Veintiuno Editores, Asociación Filosófica de México, 2007.
} 
interacciones y los procesos de aprendizaje sostenidos en estos espacios escolares. Entre otros usos, gramáticas y narrativas que abren intersticios de posibilidad por tratarse de prácticas emergentes y en constante actividad, por tanto, no cooptadas por el orden simbólico dominante y adulto. 

ALGUNAS REFLEXIONES 

Concibiendo a la escuela como un sistema de enclasamiento institucionalizado, cuyo concepto reconoce las homologías existentes entre el campo social general y el campo educativo, se analizaron los procesos de transmisión del capital escolar desarrollados en el espacio de la jornada extendida de una escuela primaria, ubicada en un barrio periférico de Villa María, Córdoba.

La estrategia metodológica -que abordó la dimensión objetiva y comprensiva del objeto- se basó en el reconocimiento y problematización sobre los distintos discursos y dispositivos áulicos e institucionales que agrupan prácticas pedagógicas y representaciones sociales de las educadoras, así como la reconstrucción de los recorridos en el campo educativo de las docentes que participan en la jornada extendida.

A modo de contextualización, se indagó el periodo 1990-2014 según las políticas públicas educativas para las infancias, con sus matices y como parte de las condiciones macro estructurales, que -en tiempos políticos diferentes y a nivel micro- se obturan -más o menos- con prácticas docentes situadas y atravesadas por componentes etnocéntricos.

Para objetivar las condiciones materiales y simbólicas del espacio en el cual se encuentra la escuela y sus alumnos/as, se abordaron datos históricos y otros que profundizan en los capitales económicos y culturales que conforman las estructuras patrimoniales de la mayor parte de las familias que allí viven. Se pudo así caracterizar al territorio como un barrio popular, habitado, en términos generales, por pobres estructurales y, en menor medida, por grupos sociales medios bajos. Además, se recuperaron las miradas de "los de adentro" y "los de afuera" las cuales remiten a una "escenografía” en la cual aparecen discursos de peligrosidad latente e ideas -compartidas por las maestras- que construyen a gran parte de los vecinos como un "otro" "extranjero" y "vago" que "vive de planes sociales".

Teniendo en cuenta el problema de la investigación, fue central definir las características de la escuela, en tanto cuerpo 
(especie de agente colectivo). Se rastrearon precisamente las conexiones que la institución establece, en perspectiva histórica, con diversos campos -el religioso, el asociativo y el estatal-, explorando las redes de agentes y recursos -a nivel nacional, provincial y local-. Se reveló que en estas redes sociales circulan diferentes miradas sobre los/as niños/as de clases populares en tanto alumnos/as, que coinciden, casi en su totalidad, en una visión de estas infancias en situación de pobreza como "carentes de".

El eje comprensivo del trabajo implicó cartografiar los significados miserabilistas que, en gran medida, re-producen la mirada enclasada y enclasante en referencia a los niños, las niñas, así como respecto a sus contextos familiares. Las tomas de posición miserabilistas de las educadoras se mapearon teniendo en cuenta las nociones de matriz de aprendizaje institucional, transversalidad de lo escolar y red de sentidos, que en el espacio escolar organizan el currículum, tanto el oculto, como el oficial.

De este modo, se analizaron los sentidos construidos en la relación pedagógica con los/as alumnos/as, describiendo y problematizando las prácticas escolares centrales y los proyectos institucionales -por ejemplo, el desarrollado en el marco del programa PIIE-, que constituyen la transversalidad de lo escolar. Desde las redes de sentidos detectadas se establecen contratos didácticos en los cuales se re-produce una concepción particular de los niños y las niñas de clases populares y del acto educativo en este contexto. Se puede afirmar que estas prácticas y discursos escolares vinculan, casi mecánicamente, a la pobreza como dificultad en el aprendizaje y adquisición de conocimientos. Estas prácticas operan en la lógica del "desde-hasta las dificultades" de los/as alumnos/as en clave individual y psicológica, reforzándose el sentido común clasista de este grupo de educadoras respecto a que estos niños/as solo deben aprender lo posible y útil para sus vidas en el barrio (con los prejuicios que esto supone). 
Asimismo, se investigó sobre la matriz institucional que organiza las prácticas cotidianas en la escuela, ampliando en cierta manera lo que sucede en la jornada extendida. Bajo esta matriz se observó cómo se estructuran contratos sociales que subordinan a los niños y a las niñas a la matriz adultocéntrica y sociocéntrica de los agentes institucionales.

Por tanto, la relación pedagógica se vacía y prima una particular autoridad pedagógica como foco de poder organizador de las prácticas escolares: el trabajo pedagógico secundario va definiendo entonces un habitus escolar asentado, principalmente, en lógicas de control social, desplazándose en dicho proceso la centralidad de la transmisión del conocimiento socialmente relevante.

En el caso de los sistemas de enclasamiento elaborados en referencia a las familias del barrio, los esquemas de percepción y acción de las maestras sostienen que las condiciones objetivas de las clases populares imposibilitarían la capacidad medianamente autónoma de producción simbólica (cultural) por parte de estos últimos. Para dar cuenta de estas condiciones materiales -de pobreza- las educadoras definen la relación que las familias establecen con el Estado, como una relación de dependencia que genera "vagos" y "oportunistas que viven de planes", estigmatizando de tal manera las estrategias de reproducción de las clases populares. Se reveló, entonces, una analogía entre "privación económica" y "privación cultura y moral". Bajo estos esquemas clasificatorios las docentes creen que las familias de sus alumnos/as no poseen expectativas referidas a las trayectorias escolares favorables de sus hijos, razón por la que, por ejemplo, no participan de la cotidianidad de la escuela, ni se encargan adecuadamente del cuidado de los hijos, especialmente, respecto a lo educativo.

Para explicar lo "razonable" de las miradas que significan estos puntos de vista de las educadoras de la jornada extendida, fue imprescindible reconstruir sus trayectorias en el espacio educativo, haciendo hincapié en el efecto de trayectoria social. Estas docentes, como grupo que define un "nosotros" frente 
a un "ellos" y que genera sistemas de disposiciones más o menos homogéneas, comparten ciertas experiencias vinculadas al campo educativo y laboral, en cuyo proceso acumularon capitales culturales acreditados por sobre el económico, por lo cual el efecto de trayectoria reproduce una representación de la posición ocupada que se estructura en relación a una clase media, trabajadora y meritocrática. De tal manera, este grupo naturaliza lógicas de distinción social vinculadas con el esfuerzo y la posesión de determinados capitales, oponiendo posiciones con las familias del barrio.

En conclusión, desde estos sentidos y prácticas enclasantes, en la escuela se transmiten pobres conocimientos para niños y niñas construidos y construidas, como pobres sujetos de conocimiento. En los esquemas de percepción y acción de estas maestras, el "destino escolar" de los/as niños/as de clases populares está signado, mayoritariamente, por el fracaso escolar. En este sentido, el trabajo pedagógico secundario pone el foco en la responsabilidad individual de los/as alumnos/as y, fundamentalmente, de sus familias, según sus “dificultades" para atravesar sin mucho éxito sus trayectorias escolares potenciales:

[...] la exclusión de las clases populares opera progresivamente, mediante formas negadas de eliminación como son el retraso como eliminación diferida, la relegación a unas vías de segundo orden que implica un efecto distintivo y de estigmatización, adecuado para imponer el reconocimiento anticipado de un destino escolar y social, y por último la concesión de títulos devaluados. ${ }^{1}$

Frente a estos procesos de dominación que tienen especificidades en el espacio escolar, las palabras de Jacques Rancière son provocadoras para ir pensando otra escuela, con otras líneas de actualización y de creatividad que se distingan de las líneas de estratificación del dispositivo escolar:

[...] todos los hombres tienen igual inteligencia [...] Solo hace falta reconocerse y reconocer en cualquier otro ser hablante el mismo poder [...] La igualdad no es fin a conseguir sino punto de partida. Quien justifica su propia explicación en

Bourdieu, P., La distinción. Criterios y bases del gusto, Op.cit., pág. 153. 
nombre de la igualdad desde una situación de desigualdad la coloca de hecho en un lugar inalcanzable. La igualdad nunca viene después como resultado a alcanzar. Ella debe estar siempre delante. Esto no es una cuestión de método, en el sentido de las formas particulares del aprendizaje, sino propiamente, una cuestión de filosofía: se trata de saber si el acto mismo de recibir la palabra del maestro -la palabra del otro- es un testimonio de igualdad o desigualdad. Es una cuestión de política: se trata de saber si un sistema de enseñanza tiene como presupuesto una desigualdad para 'reducir' o una igualdad para verificar [...]. ${ }^{2}$

La premisa de la igualdad de las inteligencias puede significar una ficción teórica, empero puede abrir posibilidades si se comprueba empíricamente, en tanto se conciba al "otro" como capaz de habitar esa posibilidad. El acto educativo tiene que ser un espacio de cuidado y exigencia: para el recibimiento del "otro y la preocupación por las condiciones materiales y simbólicas de las cuales está siendo parte, y para desafiar al "otro" a hacerse cargo de la potencia de una inteligencia de la que es portador.

Por todo esto, quedan como interrogantes pendientes profundizar cómo las miradas construidas por los agentes institucionales son interiorizadas pero también re-significadas por los niños y las niñas, en tanto alumnos y alumnas, desde los límites y potencialidades que sus condiciones de existencia y sus sistemas de disposiciones, apreciaciones, percepciones y acciones habilitan.

En este nuevo marco, es importante reconocer que un estudio crítico sobre las infancias lleva a considerar una triada de relaciones: 1) el relato teleológico hacia la adultez; 2) las disputas en campos de relaciones de fuerza, que influyen como factores reproductores de las condiciones de dominación o para la inserción de nuevas formas de transmisión intergeneracional de las

2 RAncière, J., El maestro ignorante. Cinco lecciones sobre la emancipación intelectual, Buenos Aires, Libros del Zorzal, 2007. 
culturas; 3 ) la reelaboración del orden adulto por las experiencias infantiles. ${ }^{3}$

Por lo tanto, aparecen dimensiones macro y micro sociales de la problemática: por un lado, el análisis de las fuerzas gubernamentales e institucionales que construyen, integran y legitiman formas de intervención, derechos y "arquitecturas de necesidades" sobre las infancias -junto con asunciones de género, de clases, y de generación especificas- ${ }^{4}$ moldeando, en el mismo acto, sujetos infantiles e identidades; y, por otro, las experiencias y agencias infantiles, ${ }^{5}$ generándose así procesos de negociación, contestación e interpretación de sentidos contextualizados.

Desde una perspectiva sociológica que complejiza los abordajes educativos y psicológicos sobre las experiencias infantiles en contextos pedagógicos, este libro abre entonces un campo de debates enunciando que la producción de las infancias está atravesada, en parte, por la reproducción de las desigualdades sociales.

\footnotetext{
3 Pavcovich, P., “Asir la(s) infancia(s) y hacer junto con l@s niñ@s”, VIII Jornadas de Sociología, Universidad Nacional de La Plata, 2014.

4 Para el caso trabajado se hallan estrategias de control sobre las infancias, que combinan el accionar de actores en el campo escolar y articulaciones específicas con el espacio de las políticas públicas, estructurándose, en términos generales, prácticas tales como: la psicologización de lo social, la regulación normalizante de la infancia y la adolescencia, la familiarización de los conflictos y la naturalización de necesidades y/o carencias respecto a los grupos populares (Llobet, 2006).

5 El desafío está en desarrollar una heurística centrada en las infancias que recupere la experiencia vital, intelectual y emotiva de los niños y niñas de clases populares como "portadores de saberes, de necesidades, de sentimientos [...] de una visión propia del mundo aunque también semejante a la del grupo al que pertenecen [participando de] su familia, su barrio, su grupo de amigos, su ciudad, su comunidad" (SALVIOLO, C., "20 años de derechos infantiles. Debates y perspectivas", Clase XV, Diploma Superior infancia, educación y pedagogía, Cohorte 1, FLACSO Virtual, 2014, pág. 14).
} 
BIBLIOGRAFÍA 

Abramowski, A., "Los afectos magisteriales: el problema de amar a los niños", Clase XI, Diploma superior infancia, educación y pedagogía, FLACSO Virtual, 2014.

ArIÈs, P., El Niño y la vida familiar en el antiguo régimen, Madrid, Taurus, 1987.

BAquero, R., Diker, G. y Frigerio, G. (compiladores), La Forma de lo escolar, Buenos Aires, Del Estante Editorial, 2007.

BARANGER, D., Epistemología y metodología en la obra de Pierre Bourdieu, Buenos Aires, Prometeo Libros, 2004.

Bernstein, B., La estructura del discurso pedagógico. Clases, códigos y control (Volumen IV), Madrid, Ediciones Marota S.L, 1990.

Birgin, A., Dussel, I., y Tiramonti, G., "Hacia una cartografía de la reforma curricular. Reflexiones a partir de la descentralización educativa", Revista Estudios del currículum, n², vol.1, Barcelona, Pomares Corredor, 1998.

Bolton, P., Educación y vulnerabilidad: experiencias y prácticas del aula en contextos diferentes, Buenos Aires, Editorial Stella, CELADEC, La Crujía, 2006.

Bourdieu, P., La distinción. Criterios y bases del gusto, Madrid, Taurus, 1979.

, "Le capital social. Notes Provisories", Actes de la Recherche en Sciences Sociales, $n^{\circ} 31,1980 a$.

, "Los Tres estados del capital cultural", Actes de la Recherche en Sciences Sociales, $n^{\circ} 31,1980 b$.

, El sentido práctico, Madrid, Taurus, 1994.

, Razones prácticas. Sobre la teoría de la acción, Barcelona, Editorial Anagrama, 1997.

, Capital cultural, escuela y espacio social, México, Siglo Veintiuno Editores, 1998. 
, Meditaciones pascalianas, Barcelona, España, Anagrama, 1999a.

, Intelectuales, política y poder, Eudeba, 1999b.

ca, 1999c.

, La miseria del mundo, Fondo de Cultura Económi-

Autoanálisis de un sociólogo, Barcelona, Editorial Anagrama S.A, 2004.

, Las estrategias de la reproducción social, Buenos Aires, Siglo Veintiuno Editores, 2011.

Bourdieu, P., Chamboredon, J., y Paseeron, J.c., El oficio de sociólogo: presupuestos epistemológicos, Buenos Aires, Siglo Veintiuno Editores, 1975.

Bourdieu, P. y PASSERon, J.c., La reproducción. Elementos para una teoría del sistema de enseñanza, México, Distribuciones Fontamara, S.A, 1996.

cultura, España, Siglo Veintiuno Editores, 2009.

, Los Herederos. Los estudiantes y la

BouRdieu, P. y WACQUANT, L., Respuestas por una antropología reflexiva, México, Grijalbo, 1995.

Brallovsky, D., "Los objetos escolares en la infancia", Clase X, Diploma superior infancia, educación y pedagogía, FLACSO Virtual, 2014.

Bustelo, E., El Recreo de la infancia, argumentos para otro comienzo, Buenos Aires, Siglo Veintiuno Editores, 2011.

superior Infancia, educación y pedagogía, Cohorte 1, FLACSO Virtual, 2014.

Calvo, B., Historia popular de Villa María. Tomo II, Córdoba, 1989. 
CASTRO, E., El vocabulario de Michel Foucault: Un recorrido alfabético por sus temas, conceptos y autores, Buenos Aires, Universidad Nacional de Quilmes, 2006.

Catini A., Barchetta J., y Gómez, A., "El análisis de la pobreza y las intervenciones sobre la pobreza: la complejidad como desafío", DILORETTO, M., y ARIAS, A.J, (compiladoras), Miradas sobre la pobreza: intervenciones y análisis en la Argentina posneoliberal, Editorial de la Universidad Nacional de La Plata, 2011.

Combessie, J.c., El método en sociología, París, Ferreyra Editor, 2003.

CostA, R., "La lógica de las prácticas en Pierre Bourdieu", Current Sociology, vol. 54, SAGE Publications, Londres, 2006.

CRIAdo, M. E., La escuela sin funciones. Crítica de la sociología de la educación crítica, España, Bellaterra, 2010.

DA SIIVA, T., "Cultura y currículum como prácticas de significación", Revista de Estudios del currículum, n 1, vol. 1, Pomares Corredor, 1998.

De Certeau, M., La invención de lo cotidiano l. Artes de hacer, Universidad Iberoamericana, Instituto Tecnológico y de Estudios Superiores de Occidente, 2000.

Deleuze, G., “¿Qué es un dispositivo?”, Deleuze, G., Glucksmann, A., Frank, M. y Balbier, E., Michael Foucault, filósofo, Gedisea, 1990.

Diker, G., “QQué hay de nuevo en las nuevas infancias?”, Clase VIII, Diploma superior infancia, educación y pedagogía, Cohorte 1, FLACSO Virtual, 2014.

Durkheim, E., Educación y sociología, Popular Editorial, 1975. , Las reglas del método sociológico, Buenos Aires, La Nave de los Locos, 2002.

Eco, U., La estructura ausente, Buenos Aires, Lumen, 1981. 
ElıAs, N., El proceso de la civilización: investigaciones sociogenéticas y psicogenéticas, Fondo De Cultura Económica, 1993.

EzPeletA, J. y Rockwell, R., "Escuela y clases subalternas", Cuadernos Políticos, $n^{\circ}$ 37, Editorial Era.

FALS BordA, O., "La ciencia y el pueblo: nuevas reflexiones", La investigación-acción participativa. Inicios y desarrollo, Salazar, M.C., (editora), Consejo de Educación de Adultos de América Latina, Universidad Nacional de Colombia, Editorial Popular, OEI, Quinto Centenario, 1980.

, "Orígenes universales y retos actuales de la IAP (investigación acción participativa)”, Peripecias, n 110, 2008.

Fatyass, R., Massafara, L., Pavcovich, P., Remondetti, L., y Romano, C., “Ampliando Horizontes de Posibilidades", Primeras Jornadas de Educación y Política, Universidad Nacional de Avellaneda, 2013.

Foucault, M., Historia de la sexualidad 1. La voluntad de saber, Siglo Veintiuno Editores, 1976.

, "Qu'appelle-t-on punir? Interview with Michel Foucault by Foulek Ringelheim", Revue de l'Université de Bruxelles, $\mathrm{n}^{\circ}$ 3. Bruxellas, 1984.

, Vigilar y castigar: nacimiento de la presión, Buenos Aires, Siglo Veintiuno Editores, 2004.

Fraser, N., "La lucha por las necesidades: esbozo de una teoría crítica socialista feminista de la cultura política del capitalismo tardío", Revista Debate feminista, 1989.

Freire, P., Cartas a Cristina. Reflexiones sobre mi vida y mi trabajo, México, Siglo Veintiuno Editores, 1996.

, Pedagogía de la esperanza. Un reencuentro con la pedagogía del oprimido, Buenos Aires, Siglo Veintiuno Editores, 2002.

, Cartas a quién pretende enseñar, Buenos Aires, Siglo Veintiuno Editores, 2004. 
, Pedagogía del oprimido, Buenos Aires, Siglo Veintiuno Editores, 2005.

Galli, G., Escuela secundaria y educación popular: cartografía de una experiencia, Buenos Aires, Editorial Stella, La Crujía, La Salle, 2014.

Goffman, E., Estigma. La identidad deteriorada, Buenos Aires, Madrid, Amorrortu, 2006.

Gómez, M., Gadotti, M., Mafra, J., y Fernándes, A., "Prefacio", Paulo Freire. Contribuciones para la pedagogía, Buenos Aires, Consejo Latinoamericano de Ciencias Sociales, ISBN 978-9871183-81-4.

Grignon, C. y PASSERon, J.c., Lo culto y lo popular. Miserabilismo y populismo en sociología y literatura, Buenos Aires, Nueva Visión, 1991.

Grimson, A., Los límites de la cultura. Crítica de las teorías de la identidad, Buenos Aires, Siglo Veintiuno Editores, 2011.

Gutierrez, A., Pobre como siempre. Estrategias de reproducción social en la pobreza, Córdoba, Ferreyra Editor, 2004.

Hillert, F., "Gramsci para educadores", Hillert, F., Ouviña, H., RIGAL, L., y SuÁREZ, D., (compiladores), Gramsci y la educación: pedagogía de la praxis y políticas culturales en América Latina, Buenos Aires, Editorial Noveduc, 2012.

Juárez Ramírez, G., "Círculos de cultura: una posibilidad para dialogar y construir saberes docentes", MoACIR GodotTI, M., Paulo Freire. Contribuciones para la pedagogía, 2008.

Kessler, G., Svampa, M. y Bombal, I.G., Introducción. Las reconfiguraciones del mundo popular. El Conurbano Bonaerense en la posconvertibilidad, Buenos Aires, Prometeo Libros, 2010.

KESSLER, G., Controversias sobre la desigualdad: Argentina 20032013, Cuidad Autónoma de Buenos Aires, Fondo de Cultura Económica, 2014. 
KoHAN, W., "El niño en la filosofía y la filosofía en el niño", Clase I, Diploma superior Infancia, educación y pedagogía, Cohorte 1, FLACSO Virtual, 2014.

Llach, J., Montoya, S. y Roldán, F., Educación para Todos, IERAL Regional Litoral, 1999.

Llobet, V., Políticas sociales y ciudadanía. Diálogos entre la teoría feminista y el campo de estudios de infancia, 2006. Dirección URL: http://www.fundacionmclaren.org/proyectos/ martinez7b_b.html

Llobet, V., "Las políticas para la infancia y el enfoque de derechos en América Latina: algunas reflexiones sobre su abordaje teórico", Revista de Psicología, n³, 2011.

, (compiladora), Pensar la infancia desde América Latina. Un estado de la cuestión, Buenos Aires, CLACSO, 2013.

, "Infancias, políticas y derechos", Clase III, Diploma superior Infancia, educación y pedagogía, Cohorte 1, FLACSO Virtual, 2014.

LORENA, C., Materiales de sociología de la educación y la cultura, Zero S.A, 1985.

Maduro, O., Mapas para la fiesta. Reflexiones latinoamericanas sobre la crisis y el conocimiento, Rio de Janeiro-Nueva York, Centro Nueva Tierra, 1992.

MClaren, P., La escuela como un performance ritual. Hacia una economía política de los símbolos y los gestos educativos, México, Siglo Veintiuno Editores, 1995.

Melossi, D., El estado del control social, Buenos Aires, Siglo Veintiuno Editores, 1992.

Merklen, D., "Con los pies en la tierra: la inscripción territorial de las clases populares -en Argentina y en otros lugares-", Pobres ciudadanos. Las clases populares en la era democrática (Argentina, 1983-2003), Buenos Aires, Gorla, 2005. 
Míguez, D. y Semán, P. (editores), Entre Santos, cumbias y piquetes. Las culturas populares en la Argentina reciente, Buenos Aires, Editorial Biblos Sociedad, 2006.

Minnicelli, M., Infancias en estado de excepción. Derechos del niño y Psicoanálisis, Buenos Aires, Novedad, 2010.

, “Se acabó la infancia? El derecho a la infancia y sus modos de institución y de destitución", Clase VII, Diploma superior Infancia, educación y pedagogía, Cohorte 1, FLACSO Virtual, 2014.

Noel, G., La conflictividad cotidiana en el escenario escolar: una perspectiva etnográfica, San Martín, UNSAM EDITA de Universidad Nacional de General San Martín, 2009.

Ortiz, M. y BorJas, B., "La Investigación Acción Participativa: aporte de Fals Borda a la educación popular, Espacio abierto, $\mathrm{n}^{\circ}$ 4, vol. 17, Universidad del Zulia Venezuela, 2008.

Pavcovich, P. El barrio. Lo social hecho espacio, Villa María, Córdoba, UNVM Editorial, 2008.

, Juanito laguna va a la escuela: la educación popular desde la sociología de Pierre Bourdieu, Villa María, Córdoba, Eduvim, 2010.

, “Asir la(s) infancia(s) y hacer junto con l@s niñ@s”, VIII Jornadas de Sociología, Universidad Nacional de La Plata, 2014.

Pineau, P., Historia y política de la educación argentina, Buenos Aires, Ministerio de Educación de la Nación, 2010.

Puiggrós, A., Sujetos, disciplina y currículum, en los orígenes del sistema educativo argentino, Buenos Aires, Editorial Galerna, 1990.

, ¿Qué paso con la educación argentina? Breve historia desde la conquista hasta el presente, Buenos Aires, Galerna, 2003. 
Ramírez, M.L., "La Ética, práctica de la libertad en Michael Foucault”, El saber filosófico 2, sociedad y ciencia, Martínez Contreras, J., y Ponce de León, A., (compiladores), Siglo Veintiuno Editores, Asociación Filosófica de México, 2007.

Rancière, J., El maestro ignorante. Cinco lecciones sobre la emancipación intelectual, Buenos Aires, Libros del Zorzal, 2007.

Redondo, P., “Infancia(s) Latinoamericana(s), una deuda interna, un debate pendiente", Clase XXI, Diploma superior Infancia, educación y pedagogía, Cohorte 1, FLACSO Virtual, 2014.

ROCHER, G., Introducción a la sociología general, Barcelona, Herder, 1985.

Salviolo, C., "20 años de derechos infantiles. Debates y perspectivas", Clase XV, Diploma superior infancia, educación y pedagogía, Cohorte 1, FLACSO Virtual, 2014.

Sautu, R., Boniolo, P., Dalle, P. y Elbert, R., Manual de metodología. Construcción del marco teórico, formulación de los objetivos y elección de la metodología, Buenos Aires, CLACSO, 2005.

SthaL, K., "Política social en América Latina: la privatización de la crisis", Revista Nueva sociedad, n 131, 1994.

Tenti Fanfani, E., La escuela y la cuestión social. Ensayos de sociología de la educación, Buenos Aires, Siglo Veintiuno Editores, 2007.

, Sociología de la educación, Buenos Aires, Ministerio de Educación de la Nación, 2010.

ToRres, C.A., Las secretas aventuras del Orden: Estado y Educación, Miño y Dávila Editores, 1996.

Villalta, C., "Estado, familias e infancia. Técnicas de gestión y dispositivos jurídico-burocráticos destinados a la infancia", Clase XIV, Diploma superior infancia, educación y pedagogía, Cohorte 1, FLACSO Virtual, 2014. 
Villalta, C. y Llobet, V., "Resignificando la protección. Nuevas normativas y circuitos en el campo de las políticas y los dispositivos jurídico-burocráticos destinados a la infancia en Argentina", Revista Estudios de sociología, $\mathrm{n}^{\circ}$ 36, vol. 19, UNESP.

Weber, M., Economía y sociedad: esbozo de la sociología comprensiva, México, Fondo De Cultura Económica, 1996.

ZANOTTI, A., Jóvenes y trabajo en sectores populares: representaciones, trayectorias y habitus, Villa María, Eduvim, 2010.

Zelmanovich, P. y Minnicelli, M., "Instituciones de infancia y prácticas profesionales: entre figuras de segregación y dispositivos de inscripción simbólica", Propuesta Educativa, $\mathrm{n}^{\circ}$ 37, vol. 1, 2012.

Zolo, D., "La ciudadanía en una Era Poscomunista”, Revista Agora, $\mathrm{n}^{\circ}$ 7, Buenos Aires, 1997.

Documentos oficiales, leyes, programas y proyectos

10 Años de Políticas Públicas para la Inclusión y la Igualdad, Ciudad Autónoma de Buenos, Presidencia de la Nación, 2013, ISBN 978-987-03-2510-9.

Asignación Universal Por Hijo, decreto 1602/09 del Poder Ejecutivo de la Nación, 2009.

Convención Internacional sobre los Derechos del Niño, Asamblea General de las Naciones Unidas, 1989.

Declaración Universal de los Derechos Humanos, Asamblea General de las Naciones Unidas, 1948.

Declaración de los Derechos del Niño, Asamblea General de las Naciones Unidas, 1959.

Documento Base del Programa Integral para la Igualdad Educativa (PIIE), Ministerio de Educación, Presidencia de la Nación. 
Documento Oficial de Jornada Extendida, Ministerio de Educación de la Provincia de Córdoba, 2010.

Encuesta sobre Condiciones de Vida: Niñez y Adolescencia, Ministerio de Desarrollo Social, Presidencia de la Nación, 20112012.

Ley $N^{\circ} 10.903$ de Patronato de Menores, Código Civil de la República Argentina, 1919.

Ley $N^{\circ} 26.061$ de Protección Integral de los Derechos de los Niños, Niñas y Adolecentes, Código Civil de la República Argentina, 2005.

Ley $\mathrm{N}^{\circ} 26.075$ de Financiamiento Educativo, Código Civil de la República Argentina, 2005.

Ley $N^{\circ} 26.206$ de Educación Nacional, Código Civil de la República Argentina, 2006.

Ley $N^{\circ} 9.870$ de Educación Provincial, Legislatura de la Provincia de Córdoba, 2010.

Núcleos de Aprendizajes Prioritarios, Segundo Ciclo de Educación Primaria: $4^{\circ}, 5^{\circ}$ y $6^{\circ}$ años, Ministerio de Educación, Presidencia de la Nación.

Proyecto de investigación "Prácticas de sectores populares en contextos de pobreza”, directora Pavcovich, P., Universidad Nacional de Villa María, 2012-2013.

Proyecto de investigación "Estrategias de reproducción social e infancia(s). Experiencias en niños/as y adolescentes", directora Pavcovich, P., Universidad Nacional de Villa María, 2013-2014.

Tenemos Patria: Argentina un país con derechos, Secretaría de Derechos Humanos del Ministerio de Justicia y Derechos Humanos de la Nación, 2013.

Tercer Informe Periódico de la Convención sobre los Derechos del Niño, Secretaria Nacional de Niñez, Adolescencia y Familia, Ministerio de Desarrollo Social, Presidencia de la Nación, 2008. 
Documentos institucionales

La "Historia de mi vida", 1996.

Centro de Educación No Formal "Creciendo con derechos". Fundación Familia Trinitaria, 2013.

"Un lugar para compartir". Proyecto educativo institucional, 2013.

“Aprendiendo juntos”. Proyecto educativo institucional, 2014.

"Yo puedo pero juntos podemos más". Proyecto educativo institucional, 2014.

\section{Entrevistas}

Fuentes primarias:

Entrevista a directora de escuela (2), 2014.

Entrevista a maestra de apoyo o maestra integradora, 2013.

Entrevista a maestra de Artística, Literatura, TICS e Inglés en jornada extendida (maestra 1), 2014.

Entrevista a maestra de Educación Física en jornada extendida (maestra 2), 2014.

Entrevista a maestra de Ciencias en jornada extendida (maestra 3), 2014.

Entrevista a ex voluntaria del apoyo escolar de la capilla, 2014.

Fuentes secundarias: proyecto de investigación "Prácticas de sectores populares en contextos de pobreza":

Entrevista a directora de la escuela (1), 2012. 
Entrevista a ex cocinera y catequista del apoyo escolar de la capilla, 2012

Entrevista a una de las fundadoras del dispensario y copa de leche en el barrio, 2012.

Entrevista a fundadora de una copa de leche en el barrio, 2012 Entrevista a ex trabajadora social en el dispensario del barrio, 2012.

Notas de campo, 2014

Nota de campo 1, 29-04-2014. Primera reunión con la docente de artística.

Nota de campo 2, 8-05-2014. Trabajo con títeres y primeros juegos.

Nota de campo 3, 15-05-2014. Clase suspendida.

Nota de campo 4, 23-05-2014. Reunión con la directora y recorrido por la escuela. Clase de educación física.

Nota de campo 5, 29-05-2014. Trabajo con la temática del mundial.

Nota de campo 6, 04-06-2014. Jornada escuela, familia y comunidad.

Nota de campo 7, 05-06-2014. Trabajo con planisferios. Actividad de intervención.

Nota de campo 8, 12-06-2014. Clase suspendida.

Nota de campo 9, 19-06-2014. Visita a la Tecnoteca.

Nota de campo 10, 26-06-2014. Jornada en el centro vecinal. Actividad de intervención. 
Nota de campo 11, 24-07-2014. Desarmar y armar obras de arte. Trabajo con capturadores visuales. Actividad de intervención.

Nota de campo 12, 30-07-2014. Proceso de pactar entrevistas.

Nota de campo 13, 31-07-2014. Producciones de cuentos con imágenes. Actividad de intervención.

Nota de campo 14, 01-08-2014. Proceso de pactar entrevistas.

Nota de campo 15, 05-08-2014. Proceso de pactar entrevistas.

Nota de campo 16, 07-08-2014. Cuentos de terror con linternas. Actividad de intervención.

Nota de campo 17, 14-08-2014. Historietas grupales y audios de terror. Actividad de intervención.

Nota de campo 18, 19-08-2014. Festejo del Día del Niño en la escuela.

Nota de campo 19, 21-08-2014. Producción de cuentos de terror y audios de terror. Actividad de intervención.

Nota de campo 20, 22-08-2014. Visita al rectorado (UNVM) para obra de teatro-musical. Actividad de intervención.

Nota de campo 21, 26-08-2014. Feria de ciencias.

Nota de campo 22, 27-08-2014. Reunión entre varias instituciones del barrio.

Nota de campo 23, 04-09-2014. Clase suspendida.

Nota de campo 24, 08-09-2014. Búsqueda de documentación de la escuela.

Nota de campo 25, 25-09-2014. Clase de inglés.

Nota de campo 26, 16-10-2014. Realización de tarjetas para el día de la madre. 
Nota de campo 27, 23-10-2014. Visita al campus de la UNVM, para escuchar el ensamble universitario. Actividad de intervención.

Nota de campo 28, 30-10-2014. Última clase. Finalizando la confección de títeres.

Índice de siglas

AUH: Asignación Universal por Hijo.

CAI: Centros de Actividades Infantiles.

CAJ: Centros de Actividades Juveniles.

CEMPA: Centro Educativo de Nivel Primario para Adultos.

EGB: Educación General Básica.

EPAE: Equipos Profesionales de Apoyo Escolar.

FINES: Plan de Finalización de Estudios Primarios y Secundarios.

INDEC: Instituto Nacional de Estadística y Censos de la República Argentina.

NAP: Núcleos de Aprendizajes Prioritarios.

PAICOR: Programa de Asistencia Integral de Córdoba.

PIIE: Programa Integral para la Igualdad Educativa.

PISA: Programa Internacional de Evaluación de los Alumnos.

PNBB: Programa Nacional de Becas Bicentenario.

PNBU: Programa Nacional de Becas Universitarias.

PNIE: Programa Nacional de Inclusión Educativa.

PROGRESAR: Programa de Respaldo a Estudiantes de Argentina. 
PROMEDU: Apoyo a la Política de Mejoramiento de la Equidad Educativa.

ROTARACT: Rotary en Acción.

SENAF: Secretaría de Niñez, Adolescencia y Familia.

SPSS: Statistical Package for the Social Sciences.

UD: Unidades Domésticas.

UDER: Unidades de Desarrollo Regional.

UNVM: Universidad Nacional de Villa María. 



\section{Encontranos en}

\section{www.eduvim.com}

eduvim

- $\quad$ www.eduvim.com/blog

(5) @eduvim

1 editorial_eduvim

\section{Buscanos en}

\section{Librería Universitaria Centro}

Chile 253 - Villa María (Cba.) CP 5900

C+54 (353) 4539145

Librería Universitaria Medioteca

Av. Sabattini 40 - Villa María (Cba.) CP 5900

C+54 (353) 4539118

\section{Librería Universitaria Campus}

Arturo Jauretche 1555 - Villa María (Cba.) CP 5900

librecampus@gmail.com

\section{Librería Universitaria Córdoba}

Félix Frías 60 - Córdoba Capital - CP 5004

libreriauniversitaria.cba@gmail.com

C+54 (351) 4265713

Librería Universitaria San Francisco

Trigueros 151 - San Francisco (Cba.) CP 2400

libreriauniversitariacusf@gmail.com

\section{Librería Universitaria Villa del Rosario}

Rioja 730 - Local 3 - Terminal de Ómnibus - Villa del Rosario (Cba.) CP 5963

luvilladelrosario@gmail.com

\section{Distribuidora Córdoba}

ventaseduvimcba@gmail.com

C+54 (351) 4265713

\section{Distribuidora Tramas}

Piedras 575 - Planta Baja (CABA)

Contacto: Silvia Barrios - silfeba@gmail.com

c +54 9 (11) $53277306 /+54$ (11) 43454774 
Este libro se terminó de imprimir en los talleres gráficos de Gráfica del Sur, Córdoba, Argentina, en el mes de Junio de 2019. Tirada: XXX ejemplares 